The University of Maine

DigitalCommons@UMaine

Electronic Theses and Dissertations

Fogler Library

$8-2002$

\title{
Suspended Alexandrium Spp. Hypnozygote Cysts in the Gulf of Maine
}

Sarah L. Kirn

Follow this and additional works at: http://digitalcommons.library.umaine.edu/etd

Part of the Oceanography Commons

\section{Recommended Citation}

Kirn, Sarah L., "Suspended Alexandrium Spp. Hypnozygote Cysts in the Gulf of Maine" (2002). Electronic Theses and Dissertations.

177.

http://digitalcommons.library.umaine.edu/etd/177

This Open-Access Thesis is brought to you for free and open access by DigitalCommons@UMaine. It has been accepted for inclusion in Electronic

Theses and Dissertations by an authorized administrator of DigitalCommons@UMaine. 
SUSPENDED ALEXANDRIUM SPP.

HYPNOZYGOTE CYSTS IN THE

\title{
GULF OF MAINE
}

By

Sarah L. Kirn

B.S. Brown University, 1994.5

\author{
A THESIS \\ Submitted in Partial Fulfillment of the \\ Requirements for the Degree of \\ Master of Science \\ (in Oceanography) \\ The Graduate School \\ The University of Maine \\ August, 2002
}

Advisory Committee:

David W. Townsend, Professor of Oceanography, Advisor

Mary Jane Perry, Professor of Marine Sciences and Oceanography

Neal R. Pettigrew, Associate Professor of Oceanography

Andrew Thomas, Associate Professor of Oceanography 


\title{
SUSPENDED ALEXANDRIUM SPP. HYPNOZYGOTE CYSTS IN THE GULF OF MAINE
}

\author{
By Sarah L. Kirn
}

Thesis Advisor: Dr. David W. Townsend

\author{
An Abstract of the Thesis Presented \\ in Partial Fulfillment of the Requirements for the \\ Degree of Master of Science \\ (in Oceanography)
}

August, 2002

Hypnozygote cysts are a known stage in the life cycle of Alexandrium spp.

Negatively buoyant cysts purportedly fall to the benthos where they undergo mandatory quiescence until their endogenous clock makes germination possible. If oxygen is present and the endogenous clock allows, germination will occur at a rate proportional to light and temperature. Offshore in the Gulf of Maine, where Alexandrium blooms are well documented, the paradigm of benthic cysts is problematic. Sediment surveys have found wide distribution of cysts, with highest cyst concentrations below $100 \mathrm{~m}$ in areas where deposition is favored. Germination at these depths is likely slow due to light inhibition; negative effects of burial on germination rate, and losses of cells during the transit from benthos to photic zone also present problems. 
The purpose of this study was to determine if cysts are suspended in the water column where they would be better positioned to initiate springtime Alexandrium populations. During cruises in February, April, and June of 2000, thirty liter samples were taken from the near-bottom, the top of the bottom nepheloid layer, and near surface, concentrated and stained with primulin for examination using epifluorescence microscopy. Suspended cysts were found widely distributed throughout the Gulf of Maine and Bay of Fundy. Generally, cysts were more abundant in near-bottom and top of the bottom nepheloid layer samples than in the surface. Alexandrium hypnozygote cysts were most abundant in February and least abundant in April.

As a first order assessment of the potential for planktonic cysts relative to benthic cysts to initiate springtime populations of Alexandrium vegetative cells, the following rough calculation was performed using as an example the data from the Bay of Fundy in February. In February planktonic cysts numbered on the order of $10^{2}$ cysts $\mathrm{m}^{-3}$ in surface waters in the Bay of Fundy; near bottom cyst concentrations were between $10^{2}-10^{3}$ cysts $\mathrm{m}^{-3}$. Roughly integrating total suspended cysts yields $10^{4}$ cysts $\mathrm{m}^{-2}$. Cysts in the Bay of

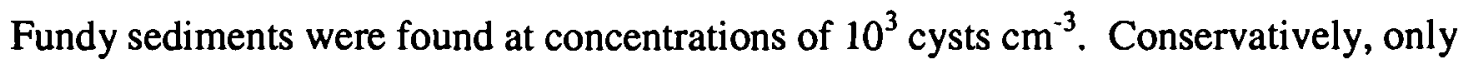
the uppermost $1 \mathrm{~mm}$ layer of cysts will be able to successfully geminate, which equals $10^{2}$ cysts $\mathrm{cm}^{-2}$ or $10^{6}$ cysts $\mathrm{m}^{-2}$. Studies have shown that only $10 \%$ of benthic cysts germinate and that light enhances germination rate 10-fold, which lowers the benthic estimate to $10^{4}$ cysts $\mathrm{m}^{-2}$, the same concentration as found in the water column.

The purpose of this study was primarily to determine the presence or absence of Alexandrium hypnozygote cysts in the water column in the Gulf of Maine. The data, while significant in that they show the presence of potentially important cyst in the water, 
do not lend themselves well to robust statistical analysis. However, this study provides evidence that suspended cysts likely contribute significantly to spring Alexandrium populations. Suspended cysts should be considered in future investigations and computer modeling designed to predict Alexandrium caused paralytic shellfish poisoning events. 


\section{DEDICATION}

This thesis is dedicated to my late grandmother, Marie Muhlfeld O'Donahoe, who received her PhD in Biochemistry from Columbia University in 1922. 


\section{ACKNOWLEDGEMENTS}

Many people made this work possible. David Townsend, who was as supportive an advisor as I could have hoped for, encouraged me to take as many classes as I wanted and generously tolerated my many interruptions of his work. My committee (Mary Jane Perry, Neal Pettigrew, and Andrew Thomas) provided helpful guidance throughout this project, especially Neal who worked through the resuspension calculations with me step by step. All the members of the Townsend lab (Stephanie Bennett, Abigail Dietz, Megan Schiff, Maura Thomas, and David Townsend) were priceless consultants, colleagues, and friends. Don Anderson of Woods Hole Oceanographic Institution and members of his laboratory (Bruce Keafer, Kristin Gribble, and Dave Kulis) were an invaluable resource when I was learning the cyst staining protocol and learning how to identify $A$. fundyense hypnozygote cysts. In addition, Don read this thesis and made many careful and invaluable comments on its content. Juliette Rooney-Varga generously opened her February cruise to the Bay of Fundy to me. Most recently, when my computer's motherboard was electrocuted one month before my scheduled defense, Steve Cousins and Peter Brickley ably diagnosed the problem and installed my blessedly unscathed hard drive into a borrowed computer. For these services and more I thank you all.

Support from friends and family made my years in Orono and Bangor interesting and enjoyable. I profited greatly from conversations regarding science, life, running, ski wax, etc. with people too numerous to list here. One deserves special mention: Annette Brickley, a true friend from the first day I met her, convinced me to come to the University of Maine, gently pestered Dave until he read my application, and was the one 
who forwarded the position announcement for my new job to me. I'm not sure how I got so lucky as to have a friend like you - thank you for all the runs, dinners, advice, laughs, and for your inspirationally calm demeanor and constant good humor.

Scientific research cannot be undertaken without financial underwriting. Funding for ECOHAB came from the National Oceanographic and Atmospheric Association and the National Science Foundation. My graduate school education was funded by the School of Marine Sciences at the University of Maine, as well as a GK-12 Teaching Fellowship from the National Science Foundation. For all of this funding I am extremely grateful. 
TABLE OF CONTENTS

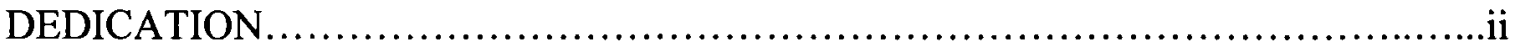

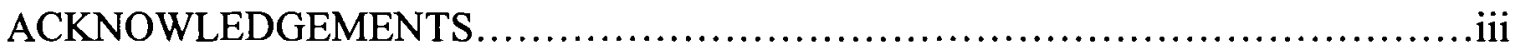

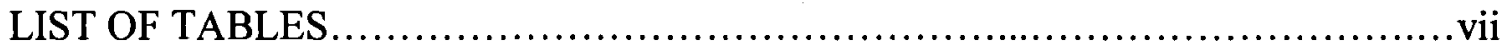

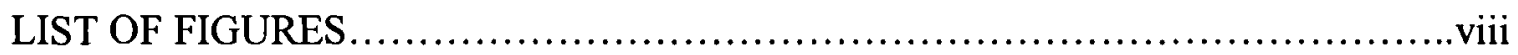

1. INTRODUCTION TO ALEXANDRIUM ...................................

Introduction to Dinophyceae............................................

Harmful Algal Blooms and the Genus Alexandrium...........................2

Alexandrium fundyense Life Cycle Stages.....................................5

Vegetative Cells......................................................

Pellicle cysts..................................................... 10

Sexual stages: gametes, planozygotes, hypnozygote cysts..............11

Planomeiocytes................................................... 21

Environmental Excystment Factors: Oxygen, Temperature, Light...............21

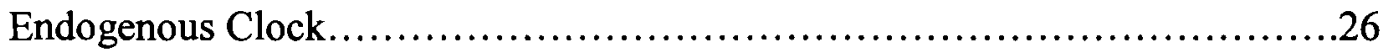

Ecological Implications of Germination Factors and Deep Benthic Cysts........27

Benefits and Limitations of Alexandrium Research in Salt Ponds..............28

Alexandrium and Paralytic Shellfish Poisoning in Gulf of Maine.................29

Possible Scenarios for A. fundyense Population Initiation in the

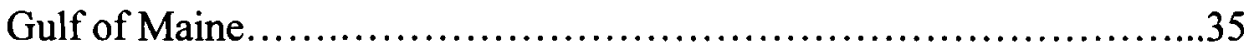

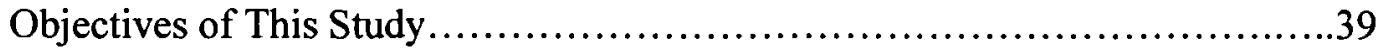

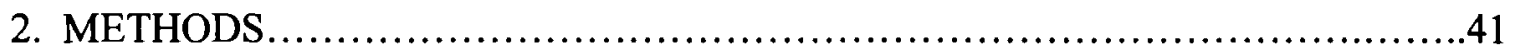

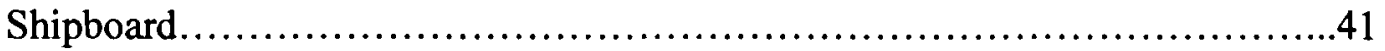


Laboratory

A note on sonification ............................................. 44

Protocol for vegetative cell subsamples of February surface samples.....45

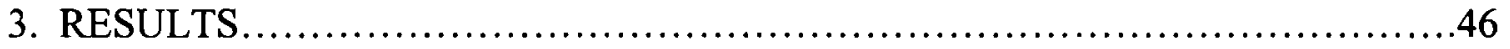

February 20-25, R/V Delaware II (Full Moon Feb 19, New Moon March 6).....46

April 24-May 2, R/V Cape Hatteras (Full Moon April 18, New Moon

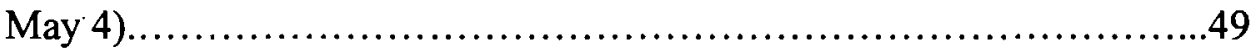

June 5 -15, R/V Cape Hatteras (New Moon June 2, Full Moon June 16)........51

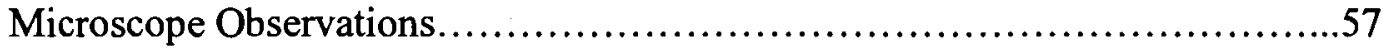

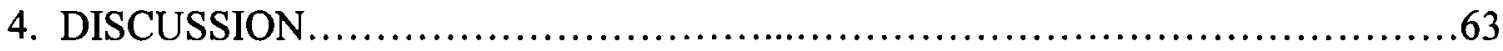

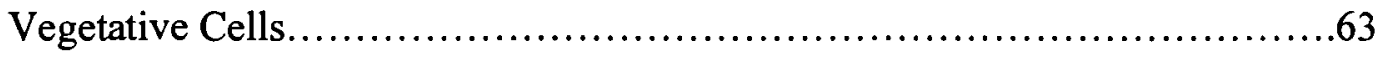

Temporal Distribution of $A$. fundyense Hypnozygote Cysts.....................63

Spatial Distribution of $A$. fundyense Hypnozygote Cysts.....................67

Numerical Abundances of Water Column Cysts and Available

Benthic Cysts.......................................................

Spatial and Temporal Resuspension Potential...............................78

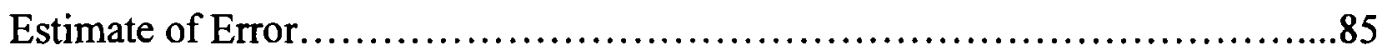

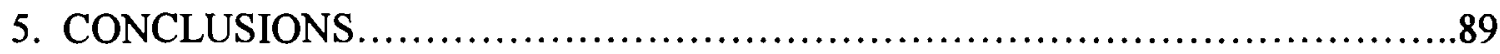

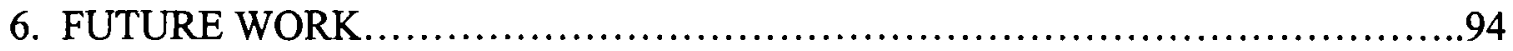

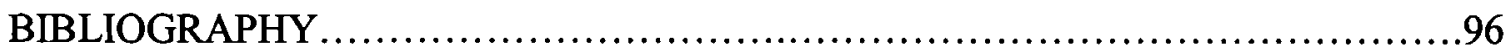

BIOGRAPHY OF THE AUTHOR............................................... 104 


\section{LIST OF TABLES}

Table 1. Alexandrium vegetative cell growth rates. Values in black were taken from paper cited. Values in blue were computed from values

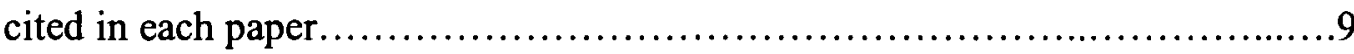

Table 2. Summary of results from germination factor studies of Alexandrium ...........25

Table 3. A. fundyense hypnozygote cyst primulin staining protocol (after Keller 1997, unpublished).

Table 4. a) Number of samples counted for each cruise at each depth and the number of samples that contained no intact cysts. b).Average intact and empty cyst concentrations, ranges (in parentheses), and standard deviation reported in cysts $\mathrm{m}^{-3}$. See Table 4 a for number of samples counted in each category

Table 5. Pooled data analysis. Average depths are reported in meters; medians, percentiles, and ranges are all reported in cysts $\mathrm{m}^{-3} .0 .2$ and 0.8 columns report first and fifth quartiles, or $20^{\text {th }}$ and $80^{\text {th }}$ percentiles; one fifth of the samples have cyst concentrations below the $20^{\text {th }}$ percentile, and one fifth of the samples have cyst concentrations above the $80^{\text {th }}$ percentile. The All Stations pool includes all samples, the Bay of Fundy pool includes samples from stations within the Bay of Fundy region northeast of a line drawn from Yarmouth, Nova Scotia, to Cutler, Maine, and the Gulf of Maine (labeled GoM-BoF) pool is all samples from stations west of the Yarmouth-Cutler line. 


\section{LIST OF FIGURES}

Figure 1. Alexandrium life cycle and stages (modified from Anderson 1998)..........6

Figure 2. Darkfield photomicrograph (100x) of live A. fundyense vegetative cells (red arrow) with Ceratium sp. (blue arrow), and Dinophysis sp. (yellow arrow), and others, from qualitative $20 \mathrm{~m}$ net tow, July 2001 cruise. Note cingulum (groove with longitudinal flagella) and sulcum (groove that partially contains the latitudinal flagella) on

A. fundyense cells.

Figure 3. Photomicrographs (200x) of A. fundyense pellicle cyst, shedded thecae still attached, in a) epifluorescence, b) transmitted light. Diameter of pellicle cyst is $28 \mu \mathrm{m}$. From July 2000 cruise, station 91 , near-bottom sample $(45 \mathrm{~m})$

Figure 4. Transmitted light photomicrographs (200x) of newly formed

A. fundyense hypnozygote cysts produced by David Kulis in

D. M. Anderson's laboratory at Woods Hole Oceanographic Institution.

a) typical capsule-shaped hypnozygote cyst, b) round form common to new hypnozygotes.

Figure 5. Photomicrographs (200x) of newly formed $A$. fundyense hypnozygote cyst in a) epifluorescence, b) transmitted light. Cyst measures $56 \times 30 \mu \mathrm{m}$. From July 2000 cruise, station 116, near-bottom sample (97 m).

Figure 6. Darkfield photomicrograph (200x) of live A. fundyense hypnozygote cyst from qualitative $20 \mathrm{~m}$ net tow, July 2001 cruise 
Figure 7. Photomicrographs (200x) of mature A. fundyense hypnozygote cyst and empty cyst wall (visible best epifluorescence image) in a) epifluorescence and b) transmitted light. Both are $48 \mu \mathrm{m}$ long. From July 2000 cruise, station 70, near-bottom sample $(212 \mathrm{~m})$

Figure 8. Photomicrographs (200x) of autofluorescent $A$. fundyense hypnozygote cyst $(50 \times 28 \mu \mathrm{m})$ in a) epifluorescence light and b) transmitted light. From July 2000 cruise, station 104, near-bottom sample (105 m) 19

Figure 9. Photomicrographs (200x) of empty A. fundyense hypnozygote cyst wall with archeopyle clearly visible in a) epifluorescence light and b) transmitted light. From April-May 2000 cruise, station 171, near-bottom sample (63 m)....22

Figure 10. General summertime circulation in the Gulf of Maine (Pettigrew, unpublished) .30

Figure 11. Map showing distribution of benthic $A$. fundyense cysts in the Gulf of Maine (Anderson, Keller, Keafer, unpublished data). 33

Figure 12. Intact cysts, February 2000. a) shows station locations and cyst concentrations. $100 \mathrm{~m}$ and $200 \mathrm{~m}$ isobaths indicated. b) shows bar graph of total intact cysts at each station with contributions from each level. 47

Figure 13. Empty cysts, February 2000. a) shows station locations and cyst concentrations. $100 \mathrm{~m}$ and $200 \mathrm{~m}$ isobaths indicated. b) shows bar graph of total intact cysts at each station with contributions from each level .48

Figure 14. Vegetative cells, February 2000. Figure shows station location and vegetative cell concentrations. $100 \mathrm{~m}$ and $200 \mathrm{~m}$ isobaths indicated. Counts reported in cell per cubic meter for consistency with cyst counts 
Figure 15. Intact cysts, April-May 2000. a) shows station locations and cyst concentrations. $100 \mathrm{~m}$ and $200 \mathrm{~m}$ isobaths indicated. b) shows bar graph of total intact cysts at stations with near-bottom and top of bottom nepheloid layer non-zero data

Figure 16. Empty cysts, April-May 2000. a) shows station locations and cyst concentrations. $100 \mathrm{~m}$ and $200 \mathrm{~m}$ isobaths indicated. b) shows bar graph of total empty cysts at stations with near-bottom and top of bottom nepheloid layer non-zero data.

Figure 17. Intact cysts, June 2000. a) shows station locations and cyst concentrations. $100 \mathrm{~m}$ and $200 \mathrm{~m}$ isobaths indicated. b) shows bar graph of total intact cysts at stations with near-bottom and top of bottom nepheloid layer non-zero data...........................................54

Figure 18. Empty cysts, June 2000. Figure shows station locations and cyst concentrations. $100 \mathrm{~m}$ and $200 \mathrm{~m}$ isobaths indicated. .56

Figure 19. Photomicrographs (100x) of two cysts: a "normal-looking" A. fundyense hypnozygote cyst (red arrow) and a cyst that lacks an eyespot (blue arrow) in a) epifluorescence and b) transmitted light. From June 2000, station 69, near-bottom sample $(240 \mathrm{~m})$ .58

Figure 20. Photomicrographs (200x) of cyst without eyespot (blue arrow) from Figure 21 in a) epifluorescence and b) transmitted light. From June 2000, station 69 , near-bottom sample $(240 \mathrm{~m})$ .59

Figure 21. Photomicrographs (200x) of new cyst in upper right $(50 \mu \mathrm{m}$ long, red arrow) and smaller, similar-looking cyst with no eyespot in lower 
left (blue arrow) in a) epifluorescence and b) transmitted light.

From June 2000 , station 25 , near-bottom sample $(48 \mathrm{~m}) \ldots \ldots \ldots \ldots \ldots \ldots \ldots \ldots \ldots \ldots$

Figure 22. Photomicrographs (200x) of mature A. fundyense hypnozygote cyst at lower right (red arrow) and "opaque" or eyespot-less cyst at left (blue arrow) a) epifluorescence and b) transmitted light. From June 2000,

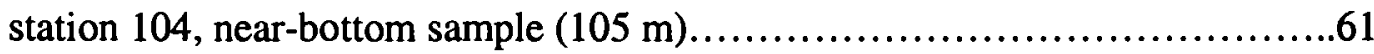

Figure 23. Photomicrographs (200x) of a small $(40 \times 25 \mu \mathrm{m})$ cyst or cell that strongly resembles an $A$. fundyense hypnozygote cyst in a) epifluorescence and b) transmitted light. From June 2000, station 116, near-bottom (97 m)......62

Figure 24. Station 11, February 2000, hydrographic data from CTD cast...............68

Figure 25. Cyst concentrations in the Bay of Fundy region and in the greater Gulf of Maine plotted against depth by cruise. In February cyst concentrations in the Bay of Fundy region are slightly higher than in the greater

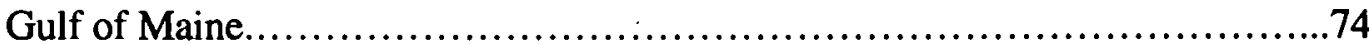




\section{INTRODUCTION TO ALEXANDRIUM}

\section{Introduction to Dinophyceae}

Dinophyceae, the class to which Alexandrium belongs, are tremendously diverse and evolutionarily successful. Dinoflagellates exist in many environments, from fresh water ponds to the deep sea, from tidal pools to pore water in sand (Sarjeant 1974). In lifestyle they are equally diverse, ranging from autotrophs to heterotrophs, symbionts to parasites. They maintain high profile positions in our world as the symbiotic zooxanthellae algae in corals, as the most important producers of bioluminescence, and as the causative algae in "red tide" or harmful algal blooms from the Biblical plagues when the Nile River ran red to present day Gulf of Maine shellfish poisoning events (Sarjeant 1974). Dinoflagellate diversity is not restricted to differences between various species; dinoflagellates have multiple life stages, some of which look different enough from each other to have been initially classified as two different organisms altogether. The variety extends to skeletal material; different species use silicate, calcite, cellulose, and/or sporopollenin in their various life stages to construct their cell walls (Evitt 1985). The only clear requirement for membership in the dinoflagellate class is the possession of a life stage with two dissimilar flagellae, which cells use to propel themselves (the name dinoflagellate comes from the Greek "dino" which means "to whirl") (Taylor 1987).

Sexual reproduction and hypnozygote stages are recognized in an increasing number of dinoflagellate species, but sexual reproduction and cysts are not universally documented among dinoflagellates. If sexual reproduction occurs the resulting zygote often enters into a dormancy period (in which case the zygote is called a hypnozygote or cyst). Sexual reproduction and dormant stages enhance species success in terms of 
genetic variability and evolutionary success. Hypnozygote cysts appear to have at least three functions in the life cycle of Alexandrium spp. and other cyst-forming species.

They provide an obvious mechanism for species survival during periods of environmental conditions adverse to vegetative cells, such as the winter months for marine dinoflagellates, and the summer months for some freshwater pond species (Evitt 1985). They also provide a mechanism for dispersal; motile cells might not survive a lengthy oceanic passage, but a dormant cyst might do so easily. Cysts can also establish perennial populations in estuaries and coastal embayments, whereas vegetative cells can enter these areas only at the whim of currents, which are just as likely to bring them out to sea again.

\section{Harmful Algal Blooms and the Genus Alexandrium}

Today, dinoflagellates are receiving increased attention due to their common occurrence in harmful algal blooms (HABs) and corresponding causative role in paralytic shellfish poisoning (PSP), diarrhetic shellfish poisoning (DSP), neurotoxic shellfish poisoning (NSP), and ciguatera poisoning outbreaks and fish kills. Because members of the Alexandrium genus have been implicated in PSP events, its worldwide distribution has been recently well documented. It may be that Alexandrium has always been widely distributed but environmental conditions have only recently supported blooms, or it may be that Alexandrium has only recently been dispersed (Hallegraeff 1993). There has been an increase of documented HAB events, specifically PSP events, through time and geography. For example, PSP has only been documented in the Southern Hemisphere since 1970 (Hallegraeff 1993) but since the late 1800s in the Northern Hemisphere (Ganong 1889). There are multiple possible explanations or mechanisms for this 
apparent trend. It may be that the apparent increase is not a trend at all, but a function of increased scientific inquiry into and documentation of these events, or a function of the increased use of coastal areas for aquaculture. If the increase is real and dispersal of HAB species rather than the onset of favorable environments is the cause, the geographic increase is likely due to dispersal of the cyst stage; "since [vegetative dinoflagellate cells] are not known to survive for long periods in the open ocean, transoceanic dispersal by means of ocean currents is highly improbable" (Scholin et al. 1995, citing Hallagraef and Bolch 1992). In addition to potential dispersal by currents, dinoflagellate cysts can be and are transported in ballast water in commercial tankers (Hallegraeff 1993). In 1995 Scholin et al. published the results of a genetics study of Alexandrium, a genus of dinoflagellates with many toxic taxa, the goal of which was to determine the dispersal history of this PSP-causing genus. They concluded that multiple sources and multiple dispersal events and probably multiple mechanisms (natural and human-mediated) have all conspired together to give us the global presence of Alexandrium we see today.

There has been much confusion over the years regarding the classification of Alexandrium spp. (Anderson et al. 1994). There exist subtle morphological and behavioral differences between strains, populations, and species, such as the presence or absence of an apical pore or small differences in sulcal plate morphology only observable with microscopy. These have presented great challenges to researchers studying harmful blooms of these species. The taxonomic difficulty and the fast pace of research needed to mitigate poisoning events help explain why Alexandrium tamarense, for example, has had so many names through the years, including Gonyaulax tamarensis, Protogonyaulax tamarensis, Gonyaulax exavata (Anderson and Lindquist 1985 paper on G. tamarensis cite paper on G. excavata Dale 1977; Yentsch, et al. 1980 refer to G. excavata in Gulf of 
Maine; Martin and White 1988 also refer to G. excavata; Ichimi et al. 2001 refer to all these as synonyms).

Three species of the dinoflagellate genus Alexandrium have been identified over the years in the Gulf of Maine: Alexandrium tamarense, A. fundyense, and a lesser abundance of A. ostenfeldii (Anderson et al. 1994; Deitz and Townsend 2000). There is little difference in motile cell taxonomy between $A$. tamarense and $A$. fundyense; $A$. ostenfeldii can be larger $(30-70 \mu \mathrm{m})$ than the other two species $(25-46 \mu \mathrm{m})$ (Anderson et al. 1994; Balech and Tangen 1985; Mackenzie et al. 1996). A. fundyense tends to be the dominant species in the open waters of the Gulf of Maine (Anderson et al. 1994); for convenience, A. fundyense is typically used to refer to the saxitoxin-producing Alexandrium species in the Gulf of Maine (e.g., A. fundyense and A.tamarense). (Saxitoxins are a family of naturally occurring, water-soluble neurotoxins, responsible for causing paralytic shellfish poisoning.) It is not yet known whether $A$. ostenfeldii from the Gulf of Maine produces saxitoxin. Worldwide, there are strains of this species that do produce toxins of this family, and strains that do not. The Gulf of Maine toxic Alexandrium spp. that are the subject of this paper will be referred to simply as $A$. fundyense.

Sexual reproduction resulting in a dormant hypnozygote is present in the three life histories of all three Alexandrium species. Alexandrium fundyense and A. tamarense produce a cyst with an oblong shape, approximately $50 \mu \mathrm{m}$ by $25 \mu \mathrm{m}$ in size (Dale 1977; Anderson and Wall 1978), which is the subject of this work. A. ostenfeldii cysts have a distinctly different round morphology (MacKenzie et al. 1996). Although both A. tamarense and A. fundyense occur in the Gulf of Maine, A. fundyense is more abundant and this name shall be used throughout this paper. 
Alexandrium has come under the study of the Ecology and Oceanography of Harmful Algal Blooms (ECOHAB) Gulf of Maine project, a large multi-institute research program. The majority of this work has been focused on the motile, vegetative cell populations, with a goal of developing the capability to predict PSP events. My thesis research is designed to complement that work by examining the distribution of $A$. fundyense hypnozygotes suspended in the water column, with the goal of furthering our understanding of how blooms are initiated.

\section{Alexandrium fundyense Life Cycle Stages}

Many dinoflagellates, as noted before, have several life stages. Although the cues that trigger an individual or population of dinoflagellates to move from life stage to life stage are not perfectly understood, the life cycle of Alexandrium has been described (Dale 1977; Anderson and Wall 1978) (Figure 1). This life cycle includes a motile vegetative cell that divides mitotically, a temporary resting cyst or pellicle cyst, motile anisogamous gametes, a motile planozygote that develops into a dormant hypnozygote cyst, and a motile planomeiocyte, the stage that emerges from the cyst (see Figure 1, Alexandrium life cycle). Although most of the previous work has consisted of laboratory experiments, studies have also been done in the research-friendly environment of salt ponds. Cape Cod salt ponds became inoculated with Alexandrium in a $1972 \mathrm{HAB}$ event and have subsequently had yearly blooms of Alexandrium (Anderson and Wall 1978; Anderson and Morel 1979; Anderson et al. 1983). 


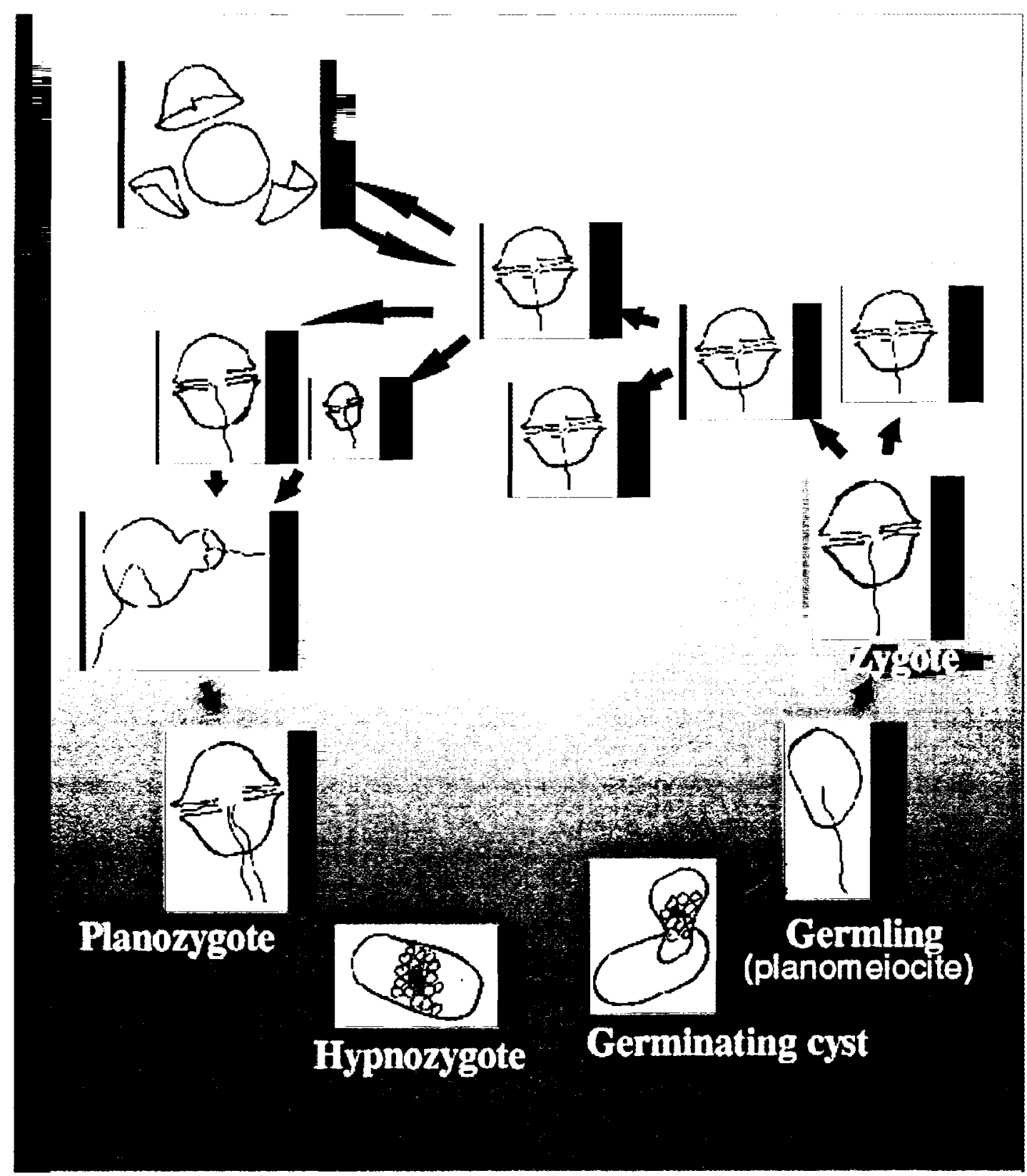

Figure 1. Alexandrium life cycle and stages (modified from Anderson 1998). 
Vegetative Cells. A. fundyense vegetative cells are found throughout the Gulf of Maine as a low concentration component of the phytoplankton community from at least April to October. Vegetative cells, or motile cells as they are sometimes called, are roughly 36 $\mu \mathrm{m}$ in diameter with two flagellae, one transverse and one longitudinal (Dale 1977) (Figure 2). Vegetative cells can swim on the order of $10 \mathrm{~m}$ per day (Anderson, personal communication). Gonyaulax polyedra, a thecate dinoflagellate of comparable size to $A$. fundyense, is capable of swimming over $20 \mathrm{~m}$ per day (Kamykowski et al. 1992). Published growth rates for $A$. fundyense vary considerably, from 0.3 doublings per day (Anderson et al. 1983; Flynn et al. 1996; Ichimi et al. 2001) to 0.7 doublings per day (Anderson and Lindquist 1985, using culture strain isolated from a salt pond) with most field studies measuring 0.3 doublings per day (Anderson et al. 1983; Ichimi et al. 2001) (see Table 1). Studies have found different optimal temperature and salinity conditions for growth, indicating that some variation exists, as expected, between natural populations (Ichimi et al. 2001).

Much variation has been found in the behaviors of closely related strains of $A$. fundyense. In identical studies designed to assess diel vertical migration of seven different strains of $A$. fundyense vegetative cells (three from Casco Bay cysts, three from Bay of Fundy cysts, and one Gulf of St. Lawrence strain) Cullen (personal communication) found enormous variability in behaviors. Some strains migrated, some did not, some migrated before nutrients were depleted at the surface, and there was no consistency among strains from the same place of origin. Most surprising, the Gulf of St. Lawrence strain that had previously been found to perform diel vertical migration in 


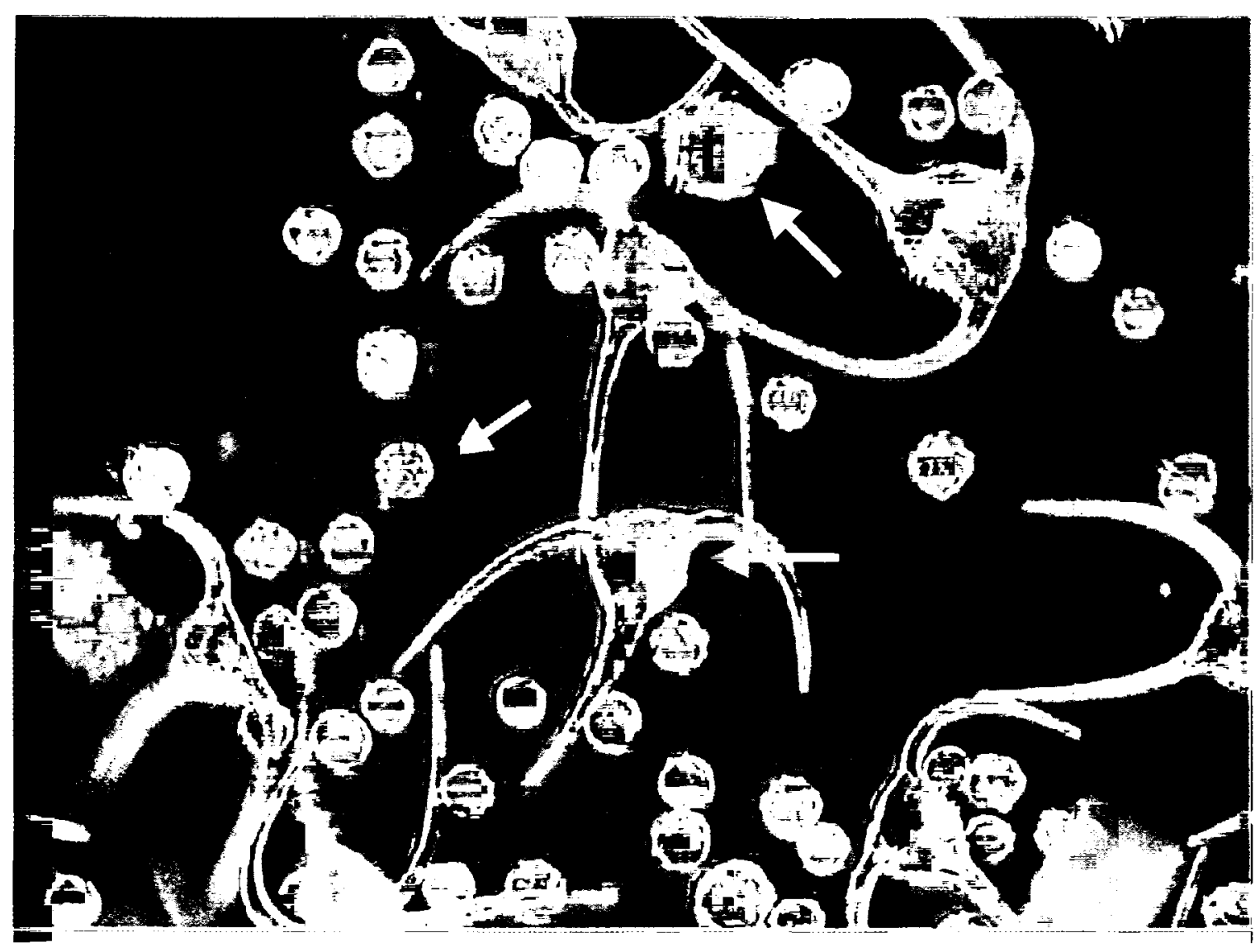

Figure 2. Darkfield photomicrograph (100x) of live A. fundyense vegetative cells (red arrow) with Ceratium sp. (blue arrow), Dinophysis sp. (yellow arrow), and others, from qualitative 20 m net tow, July 2001 cruise. Note cingulum (groove with longitudinal flagella) and sulcum (groove that partially contains the latitudinal flagella) on $A$. fundyense cells. 


\begin{tabular}{|c|c|c|c|}
\hline \multirow[t]{2}{*}{ Reference } & \multirow{2}{*}{$\begin{array}{l}\text { Where strain is from, what } \\
\text { species }\end{array}$} & \multicolumn{2}{|c|}{ Growth rate reported } \\
\hline & & Doublings & Specific \\
\hline Ichimi 2001 & NE Japan & $\begin{array}{l}0.33 \text { divisions day }{ }^{-1} \\
\text { In situ growth rate } \\
\text { estimated from } \\
\text { plotting abundances } \\
\text { from study, }\end{array}$ & $\mu=0.2 \mathrm{day}^{-1}$ \\
\hline Anderson and Lindquist 1985 & $\begin{array}{l}\text { Mill Pond (Cape Cod) } \\
\text { isolated cyst, strain GTMP }\end{array}$ & 0.7 divisions day ${ }^{-1}$ & $\mu=0.5$ day $^{-1}$ \\
\hline Flynn, Jones, Flynn 1996 & $\begin{array}{l}4 \text { Alexandrium species: } \\
\text { minutum } \\
\text { minutum } \\
\text { tamarense } \\
\text { affini }\end{array}$ & $\begin{array}{l}0.7 \text { doublings day } \\
0.6 \\
0.3 \\
0.7\end{array}$ & $\begin{array}{l}\mu_{\max }=0.5 \\
\mu_{\max }=0.45 \\
\mu_{\max }=0.23 \\
\mu_{\max }=0.5\end{array}$ \\
\hline $\begin{array}{l}\text { Cullen (personal } \\
\text { communication, unpublished) }\end{array}$ & $\begin{array}{l}\text { A. tamarense (Casco Bay) } \\
\text { " Strain } 2 \\
\text { "Strain } 3 \\
\text { A. tamarense (Bay of Fundy) } \\
\text { " strain } 2 \\
\text { "strain } 3 \\
\end{array}$ & $\begin{array}{l}0.59 \\
0.67 \\
0.69 \\
0.65 \\
0.58 \\
0.66\end{array}$ & $\begin{array}{l}\mu_{\max }=0.411 \\
\mu_{\max }=0.461 \\
\mu_{\max }=0.478 \\
\mu_{\max }=0.447 \\
\mu_{\max }=0.400 \\
\mu_{\max }=0.458\end{array}$ \\
\hline $\begin{array}{l}\text { Anderson, Chisholm, Watras } \\
1983\end{array}$ & $\begin{array}{l}\text { In situ studies of Perch, Salt, } \\
\text { and Mill Ponds on Cape Cod }\end{array}$ & $\begin{array}{l}0.4 \text { doublings } \\
0.2 \\
0.2\end{array}$ & $\begin{array}{l}\mu=0.3 \text { day }^{-1} \\
\mu=0.16 \text { day }^{-1} \\
\mu=0.16 \text { day }^{-1}\end{array}$ \\
\hline
\end{tabular}

Table 1. Alexandrium vegetative cell growth rates. Values in black were taken from paper cited. Values in blue were computed by this author from values cited in each paper. 
response to a nitricline (MacIntyre et al. 1997) no longer vertically migrated (Cullen, personal communication). These strains were all isolated from individual cells or cysts. It is therefore likely that the variation in behaviors exists in stages other than the vegetative cells. Variation in A. fundyense behavior has been found by many researchers, which suggests that this variability is likely not an artifact of laboratory methods, but represents true intraspecific variation. Thus, laboratory studies may not be easily extrapolated to other strains or populations.

The implication of these growth rates is that blooms must develop relatively slowly, requiring a fairly long time of favorable growth for normal, low concentration populations to reach bloom densities. For instance, starting with a population density of 10 cells $/$ liter and using the simple population growth equation $P(t)=P_{0} 2^{g t}$ (where $P(t)$ is the population concentration at some time $t, P_{0}$ is the population at time zero, $g$ is the doubling rate, and $t$ is the time in days) and using a $g$ of 0.3 doublings per day, 23 days (with no losses) must pass to reach a population density over $1000 \mathrm{cells} / \mathrm{liter}$.

Pellicle cysts. During times of environmental stress, vegetative cells can shed their thecae and become pellicle, or temporary cysts - athecate nonmotile cells of spherical or ovoid shapes (Anderson and Wall 1978) (Figure 3). Internal structures can either resemble those of motile cells or hypnozygotes (Anderson and Wall 1978). A. fundyense is capable of surviving for one to seven months in this temporary stage while environmental conditions are unsuitable before they must resume the vegetative cell stage or die. Most pellicle cysts are not viable after only two months (Anderson and Wall 1978). 
To avoid confusion, the word "cyst" will hereafter refer only to the hypnozygote cyst stage. If the temporary or pellicle cysts stage is discussed, it will be referred to explicitly as such.

Sexual stages: gametes, planozygotes, hypnozygote cysts. In response to an indeterminate factor or factors vegetative cells split and form gametes that are of approximately the same size as vegetative cells (Anderson 1980). Gametes (from different parental vegetative cells) fuse into a motile planozygote with a characteristic large, deeply pigmented appearance (Turpin et al. 1978). The planozygotes develop into the hypnozygote cyst within about a week, although the cellulose cell wall of the hypnozygote, or cyst, continues to thicken over the following weeks or months (Anderson 1980; Anderson et al. 1983; Yentsch et al. 1980; Anderson and Lindquist 1985). Newly formed cysts have very distinctive morphology (Anderson 1980); they are dark and full of round starch granules (see Figures 4 and 5). Cysts are as toxic or more so than vegetative cells (Dale et al. 1978). These hypnozygote cysts are usually capsuleshaped and $45-55 \mu \mathrm{m}$ by $25-30 \mu \mathrm{m}$, although shape and size vary somewhat (Dale 1977; Anderson and Wall 1978; Anderson 1980; Anderson, et al. 1985) (Figure 6 and 7). Anderson and Wall (1978) reported cysts isolated from a salt pond ranging in length from $43-72 \mu \mathrm{m}$, in diameter from $26-39 \mu \mathrm{m}$ and varying in shape from squat to elongated capsules, to bean- or peanut- shaped forms (i.e., somewhat dented and bent in the middle). Anderson et al. (1985) noted a $44 \%$ variation in size that seemed consistent with the source of the cysts: cysts from sampling sites offshore of Cape Ann were smaller than cysts isolated in Cape Cod salt ponds. 


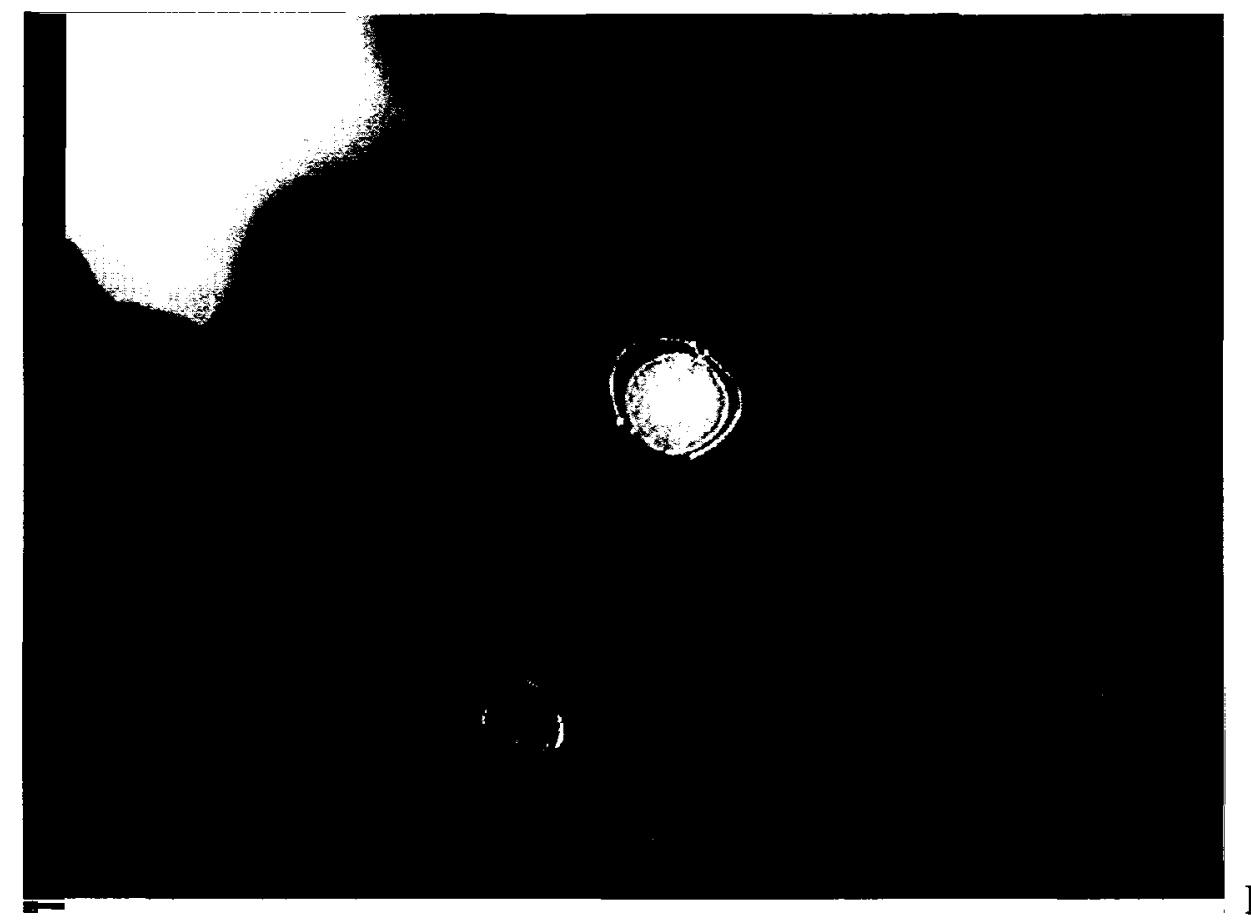

Figure 3 a

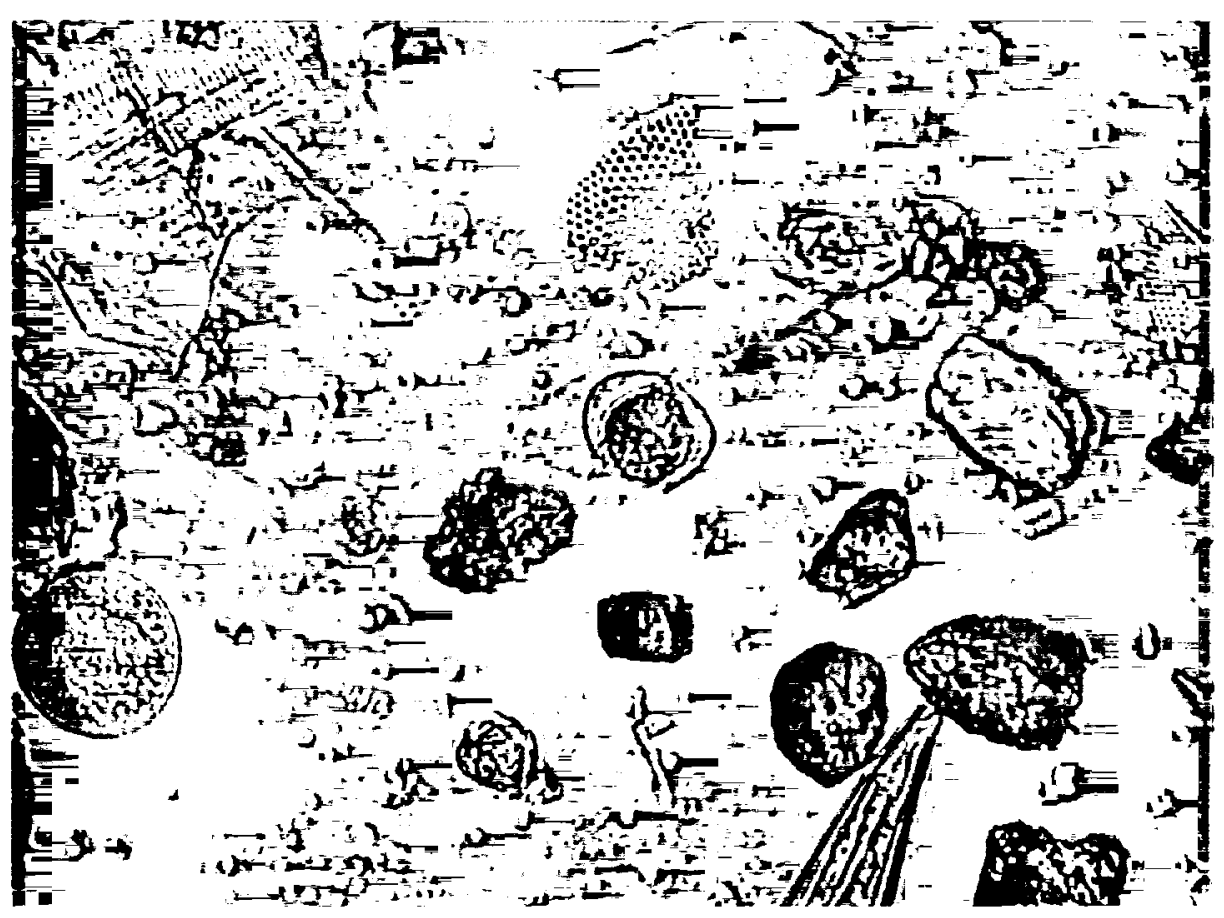

Figure 3 b

Figure 3. Photomicrographs (200x) of $A$. fundyense pellicle cyst, shedded thecae still attached, in a) epifluorescence, b) transmitted light. Diameter of pellicle cyst is $28 \mu \mathrm{m}$. From July 2000 cruise, station 91 , near-bottom sample (45m). 


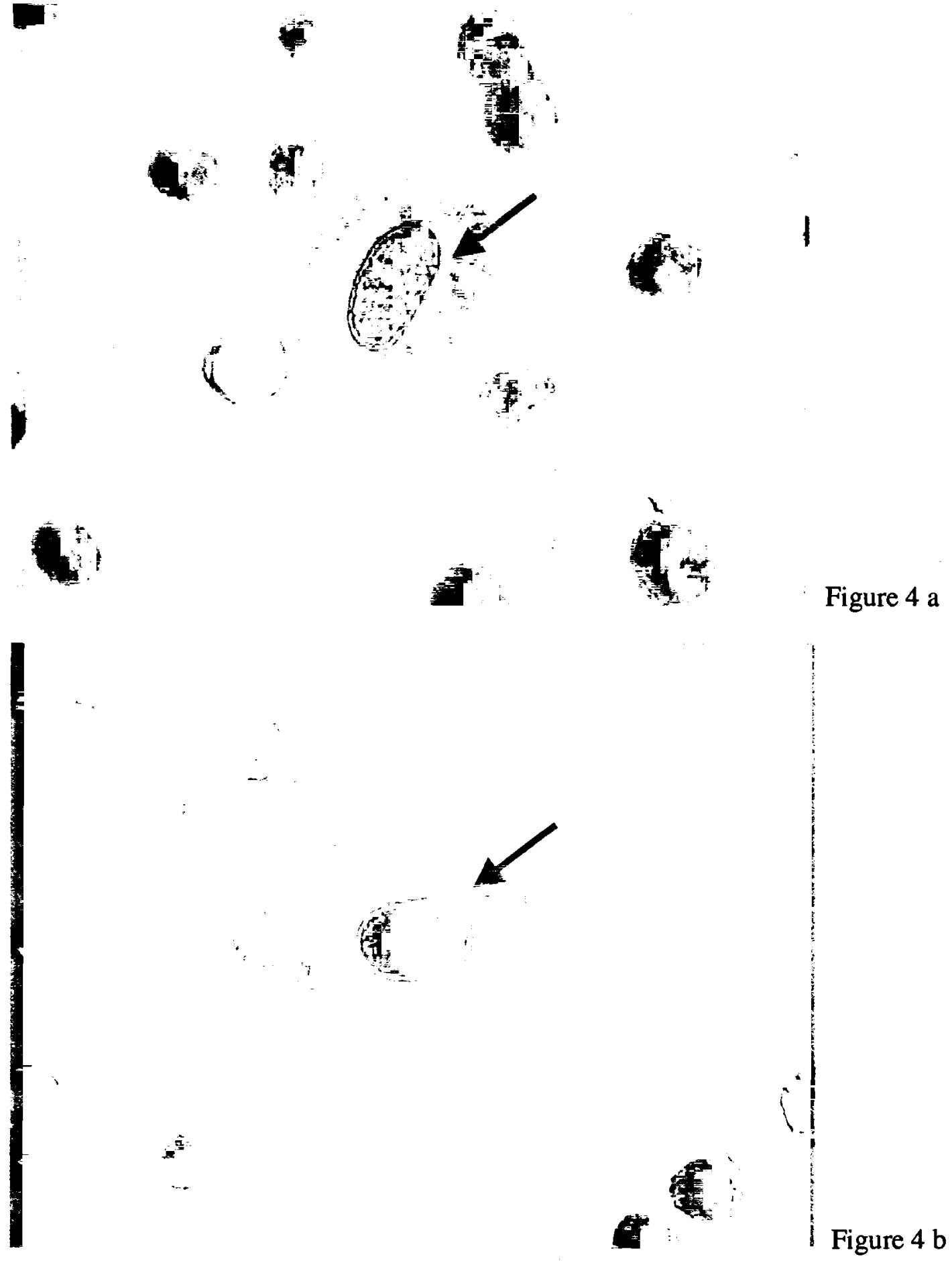

Figure 4. Transmitted light photomicrographs (200x) of newly formed A. fundyense hypnozygote cysts produced by David Kulis in D. M. Anderson's laboratory at Woods Hole Oceanographic Institution. (a) typical capsule-shaped hypnozygote cyst, (b) round form common to new hypnozygote. 


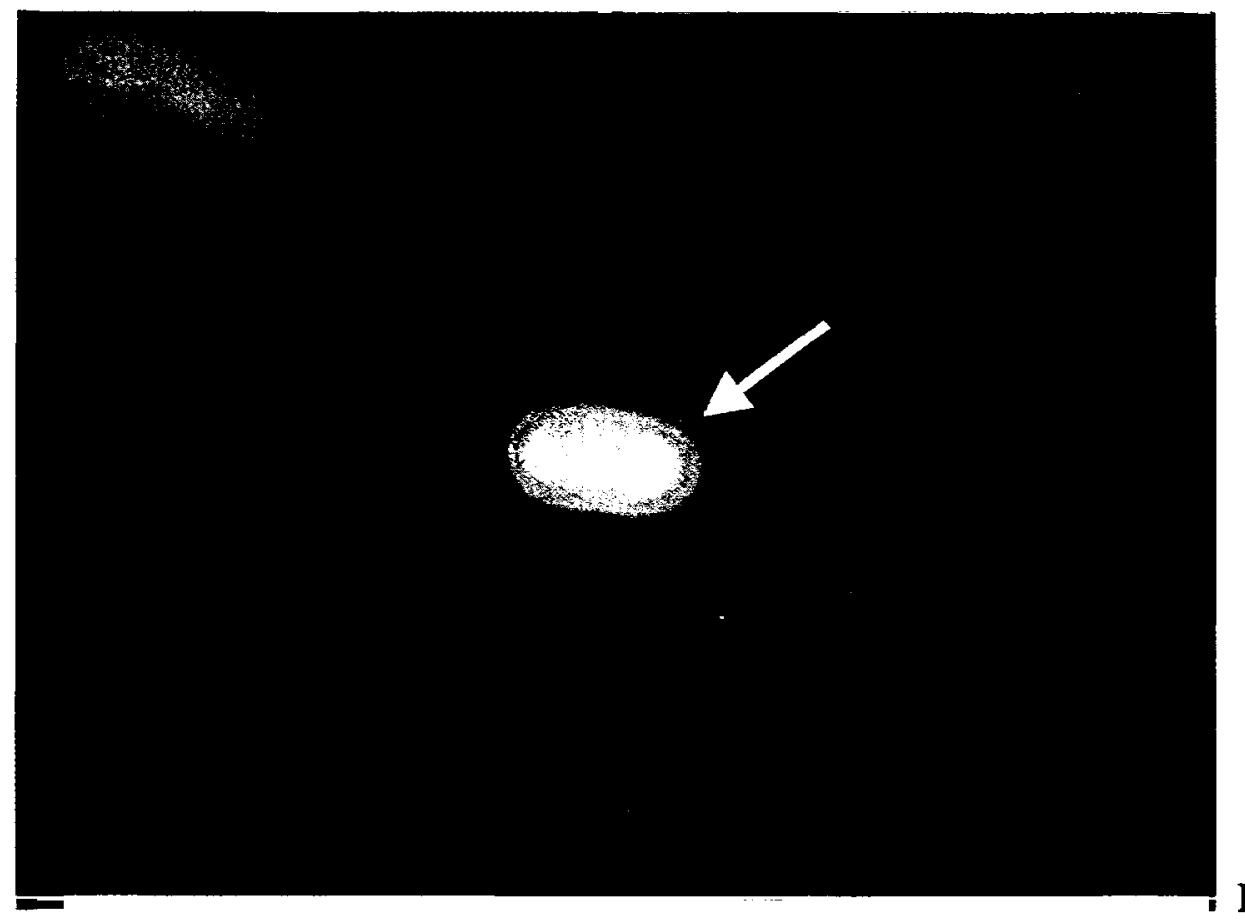

Figure 5 a

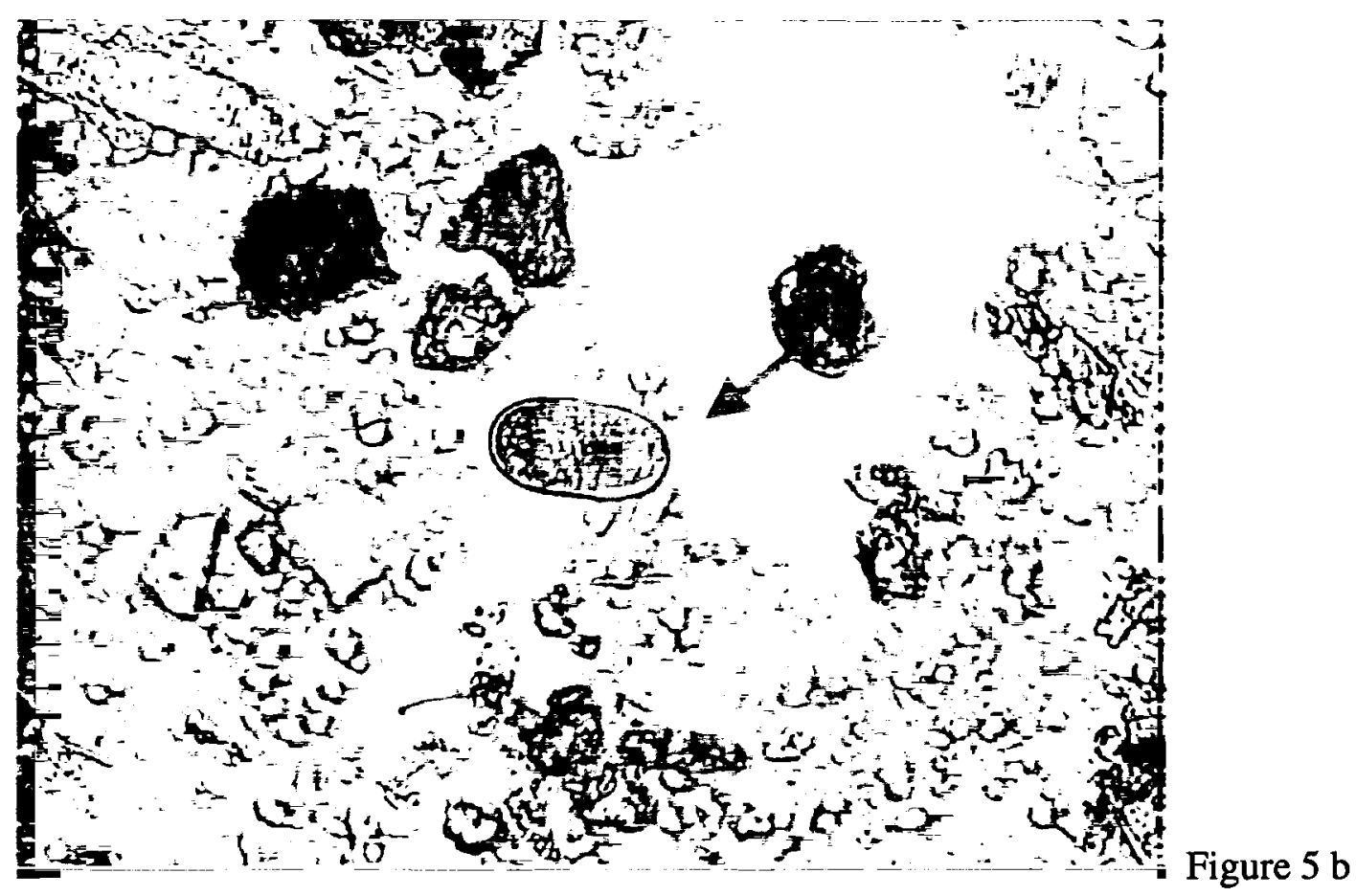

Figure 5. Photomicrographs (200x) of newly formed $A$. fundyense hypnozygote cyst in a) epifluorescence, b) transmitted light. Cyst measures 56 x $30 \mu \mathrm{m}$. From July 2000 cruise, station 116 , near-bottom sample $(97 \mathrm{~m})$. 


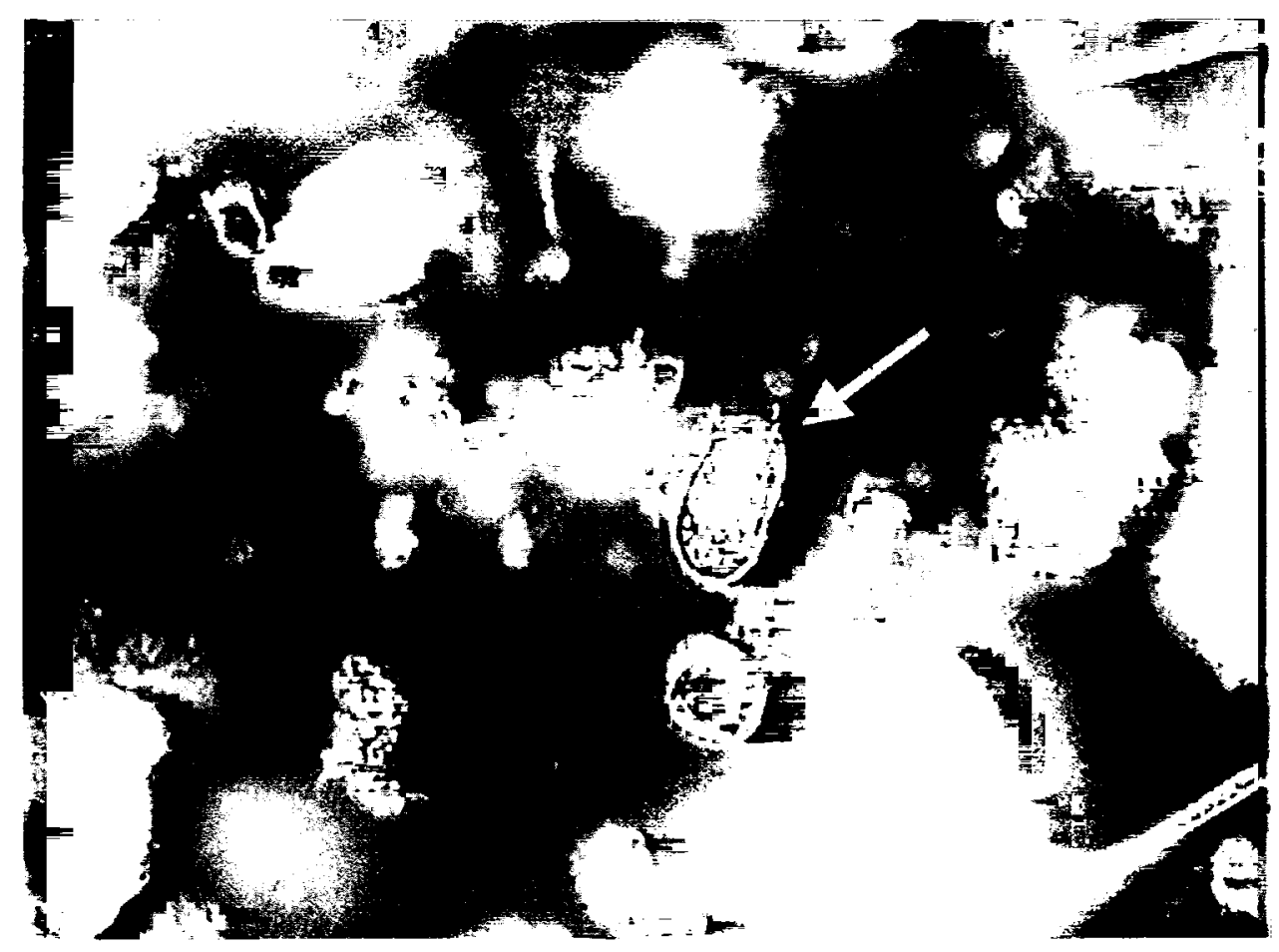

Figure 6. Darkfield photomicrograph (200x) of live A. fundyense hypnozygote cyst from qualitative $20 \mathrm{~m}$ net tow, July 2001 cruise. 


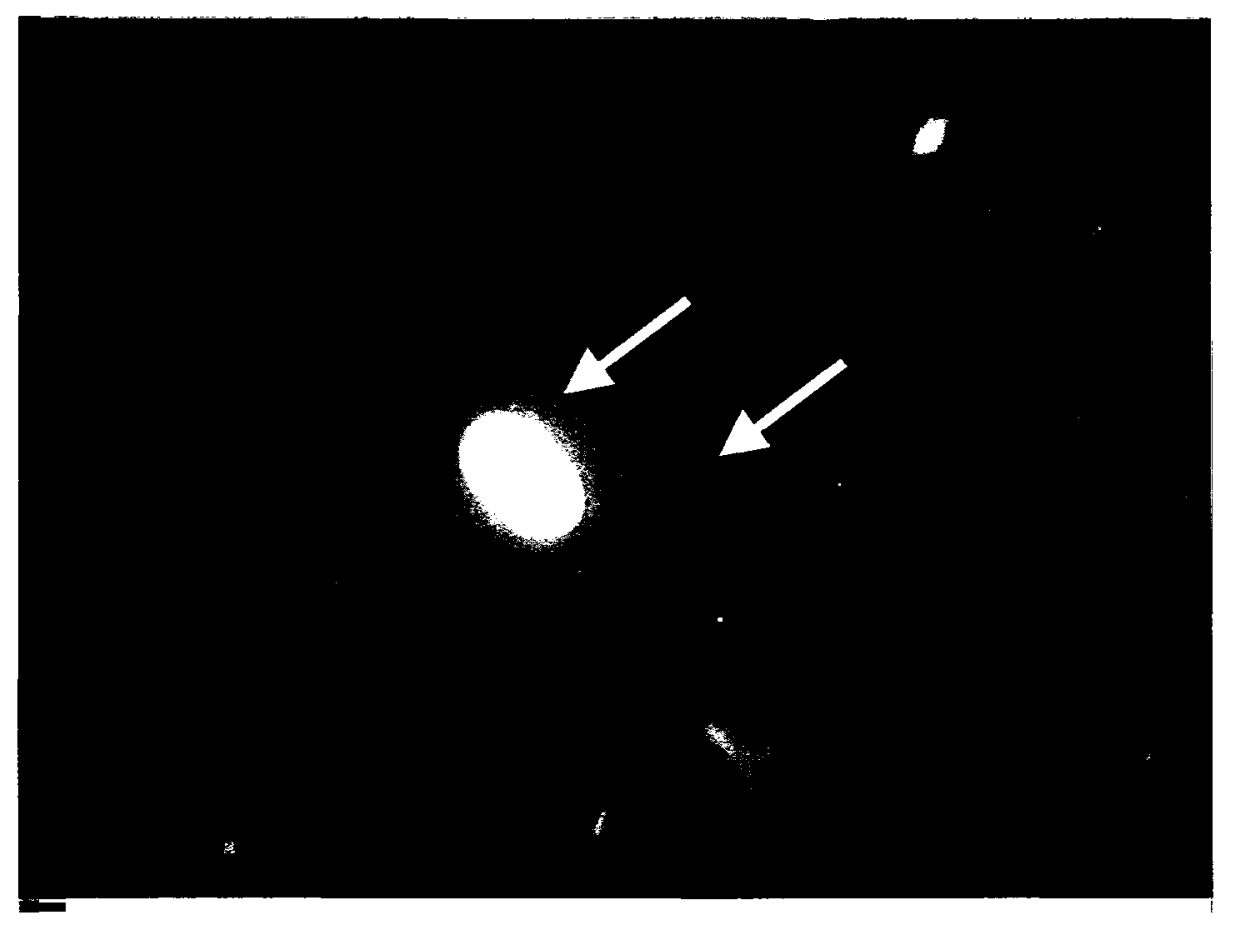

Figure 7 a

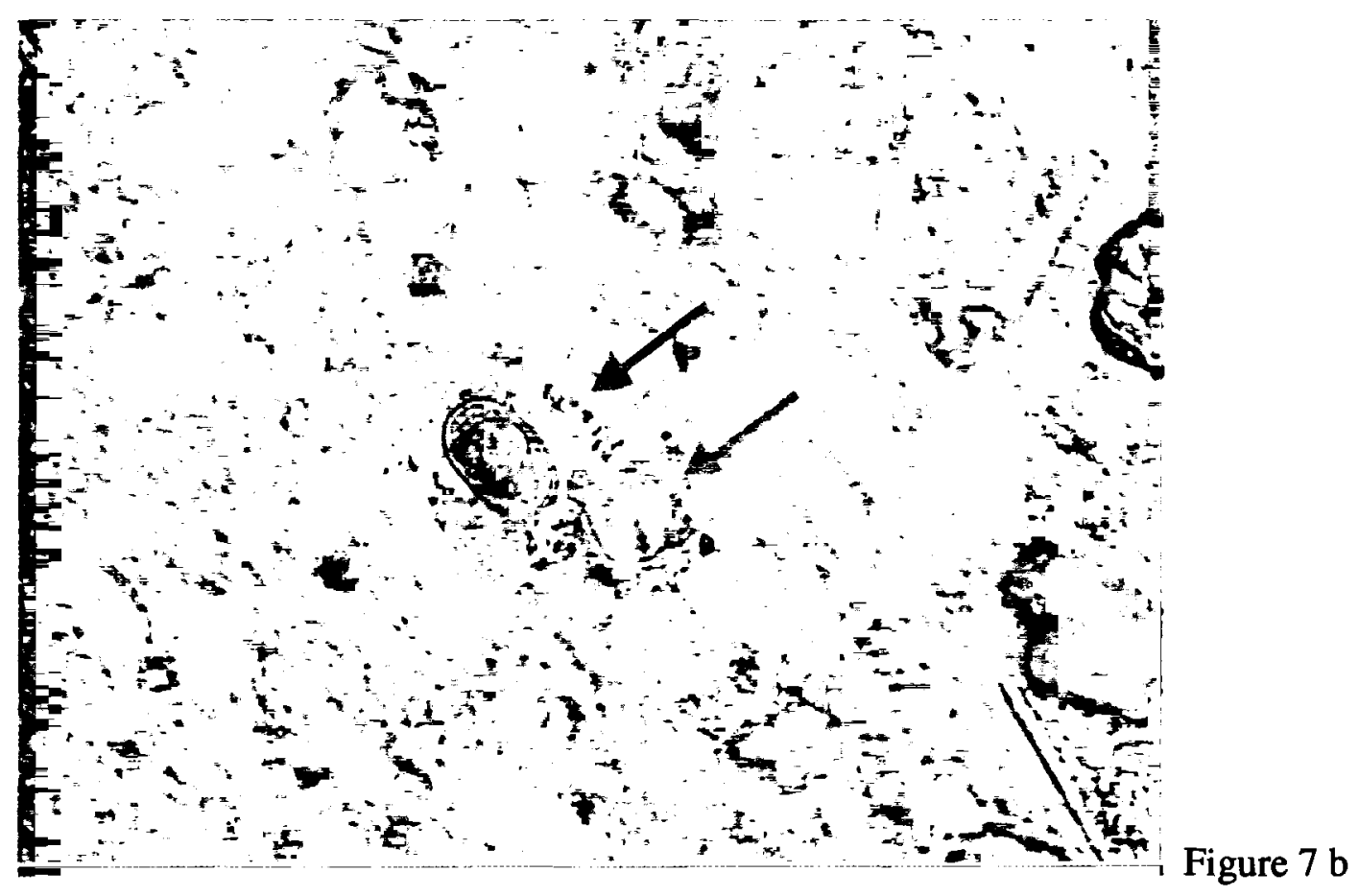

Figure 7. Photomicrographs (200x) of mature A. fundyense hypnozygote cyst and empty cyst wall (visible best in epifluorescence image) in a) epifluorescence and b) transmitted light. Both are $48 \mu \mathrm{m}$ long. From July 2000 cruise, station 70, near-bottom sample $(212 \mathrm{~m})$. 
With a density of $1.24-1.4 \mathrm{~g} \mathrm{~cm}^{-3}, A$. fundyense cysts are negatively buoyant (Anderson et al. 1985; Yamaguchi et al. 1995). Empty cyst walls have densities similar to that of cellulose, on the order of $1.05 \mathrm{~g} \mathrm{~cm}^{-3}$ (Anderson et al. 1985). In a motionless water column, cysts would sink with a Stokes velocity of between 8.4 and $14.5 \mathrm{~m} \mathrm{day}^{-1}$. Larger cysts would fall slightly faster than smaller cysts, a fact that has ecological implications for cyst size variability. Anderson et al. 1985 calculated that the sinking rate of salt pond cysts was $32 \%$ faster than that of the $44 \%$ smaller Cape Ann cysts. It is well known that the Gulf of Maine water column is far from motionless, so actual sinking rates are likely much slower or much faster than Stokes velocity calculations suggest. Different sinking velocities among cyst populations are consistent with the idea of two different adaptive strategies for cysts occurring in shallow and deep water. Cysts that settle quickly might be more likely to establish a perennial population in a shallow environment and less likely to be advected out of the area. Cysts that sink slowly might never reach the bottom in deep water but remain suspended in turbulent environments and therefore might still be in the water column months later when germination occurs.

Cysts are often, though not always, observed covered in mucilage, which may aid their passive decent. Mucus can increase the effective radius of a cyst. If the mucus captures particles denser than the cyst, this would increase the density of the cyst. Both of these mechanisms would increase sinking rate (Anderson and Wall 1978; Yamaguchi et al. 1995). Cysts apparently secrete mucilage themselves, as it is seen in cultured Alexandrium cysts (Anderson 1980; Anderson et al. 1985), although mucilage is apparently not ubiquitous among Alexandrium cysts. Yamaguchi et al. (1995), in a study of cysts from natural sediment samples, found twice as many cysts with associated detrital material than cysts with no associated detrital material. Cysts with detrital 
material were found almost exclusively in the greater than $1.4 \mathrm{~g} \mathrm{~cm}^{-3}$ fraction of their density fractionation study. Cysts that do not have mucilage might remain suspended longer in the water column. This dichotomy between fast sinking mucilage-covered cysts and slower sinking bare cysts could be advantageous in two ways. Fast-falling cysts could act to establish permanent populations in areas where water depth is shallow or advection is strong. Slower-sinking cysts would be more effective in dispersing the species over wide areas.

Yentsch et al. (1982) observed changes in cyst wall thickness, toxin content, appearance of inner contents, and fluorescence over the course of the winter. These authors interpreted these changes, as well as mucilage production, as evidence of metabolic activity and perhaps indicative of an endogenous clock or circannual rhythms. Other researchers have noted changes in cyst appearance as well, especially when the cyst is recently formed or just prior to germination. New cysts appear distinctively dark and full of round starch and lipid bodies (Anderson 1980). They can sometimes be less elongate than more mature cysts. This appearance lasts only days to a week after the cyst is formed. As cysts get close to germination a clear girdle forms through the middle, and the internal contents show increased Brownian motion and autofluorescence (Anderson and Wall 1978) (see Figure 8).

Initiation of sexual reproduction and subsequent cyst formation can be a significant factor in bloom termination (Anderson et al. 1983; Heiskanen 1993; Yamamoto et al. 2002). What triggers sexual reproduction in an $A$. fundyense population is unknown, although many theories exist. Using a Pacific strain of Gonyaulax tamarensis (later renamed A. tamarense) Turpin et al. (1978) induced cyst formation by putting vegetative cells into a low nitrogen medium. Doucette et al. (1989) found in 


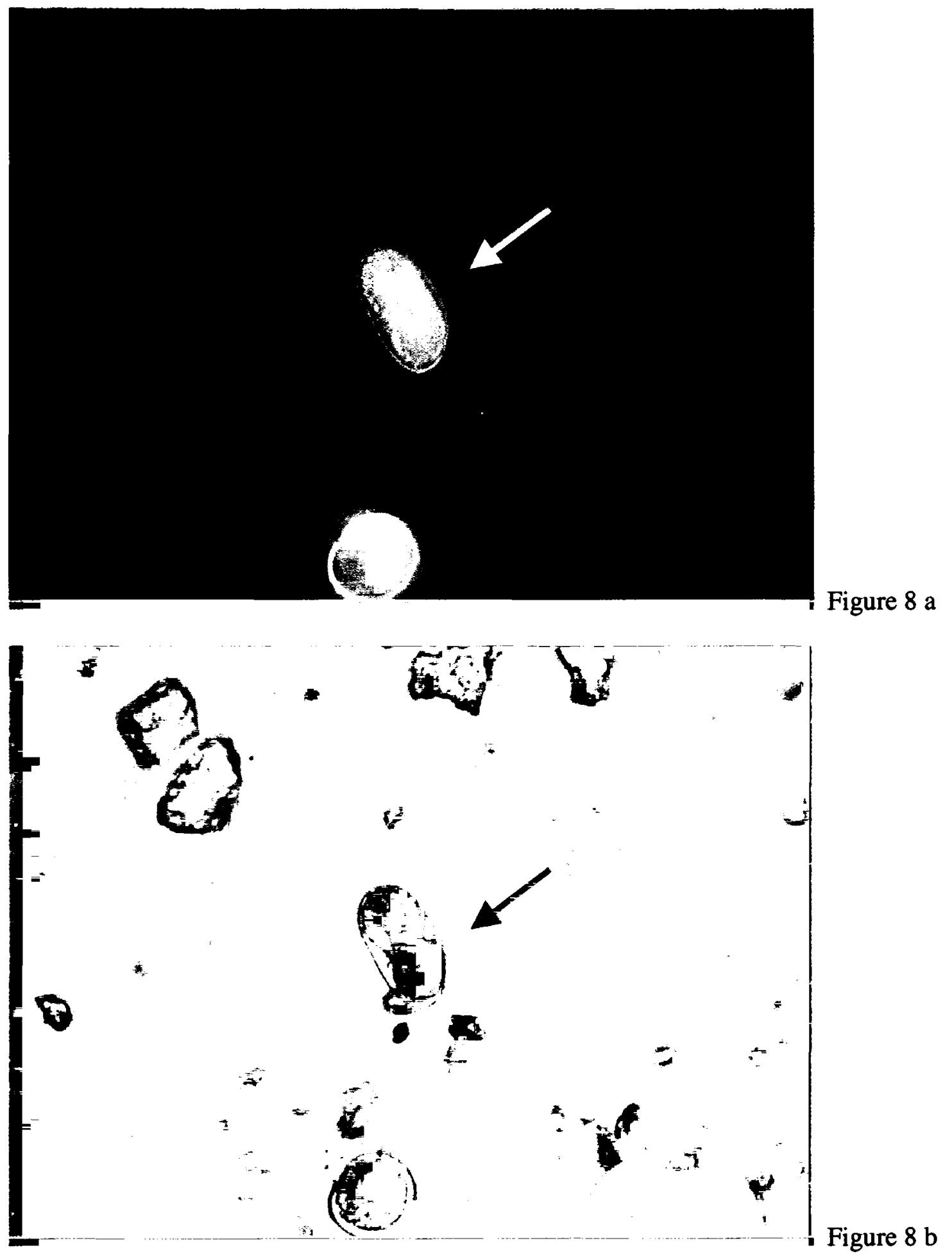

Figure 8. Photomicrographs (200x) of autofluorescent A. fundyense hypnozygote cyst $(50 \times 28 \mu \mathrm{m})$ in a) epifluorescence and b) transmitted light. From July 2000 cruise, station 104 , near-bottom sample $(105 \mathrm{~m})$. 
laboratory experiments that Fe stress initiated sexuality, however, the study produced low encystment rates and $\mathrm{Fe}$ stress more often resulted in pellicle cyst formation than hypnozygote cyst formation. Anderson and Lindquist (1985), in a series of phosphoruslimited batch culture studies, found that nutrient limitation seemed to initiate reproduction, although they cited some fieldwork that indicated encystment in the presence of high nutrients. In a salt pond study examining sexuality in G. tamarensis sexual reproduction was initiated at relatively high nutrient concentrations similar to those earlier in the bloom when asexual reproduction was occurring. This lead researchers to speculate that nutrient limitation may not have induced sexual reproduction in that salt pond environment (Anderson et al. 1983). Alternatively, these authors suggest that the increased metabolism and higher growth rates at higher temperatures later in the bloom led to nutrient limitation at the same nutrient concentrations present during the early stage of the bloom. A drop in temperature did not commence sexual reproduction either, as the temperature in the salt ponds remained high (Anderson $e t$ al. 1983). These authors suggested the possibility that initiation of sexual reproduction is driven by the depletion of cellular contents; in other words, vegetative cells released from a cyst can only divide a set number of times before they must resume their dormant phase. But since then, cellular depletion has been ruled out in laboratory studies as a mechanism for inducing sexual reproduction in other dinoflagellates (Olli and Anderson 2002). Because the salt pond study was made in the field away from potential culture and laboratory bias, it is perhaps more compelling than the others. It is also consistent with observations that cyst formation is an important mechanism by which blooms are terminated (Anderson et al. 1983; Heiskanen 1993; Yamamoto et al. 2002). We can safely say that cysts do form in surface waters where the vegetative population resides 
and, because fusion of gametes must occur in order for the cysts to form, the concentration of cells must be fairly high when sexual reproduction occurs, i.e., near the peak of the vegetative cell bloom.

Hypnozygote cysts have a mandatory dormancy period on the order of 2-6 months (Anderson 1980). There is evidence that the length of dormancy is temperature dependent, with excystment being possible earlier in cysts incubated at warmer temperatures (Anderson 1980). Cysts can survive burial in sediments for many years and still germinate successfully (Keafer et al. 1992).

Planomeiocytes. Planomeiocytes, also called germlings or germling cells, emerge amoeba-like from the archeopyle in the cyst wall (see Figure 9). They are posteriorly biflagellated, diploid, and at 40-50 $\mu \mathrm{m}$, larger than vegetative cells (Anderson and Wall 1978). Soon after excystment, the planomeiocytes undergo their first division within 24 hours (Anderson and Wall 1978), within 12-36 hours for a variety of dinoflagellate species (Nehring 1996), and within 2-3 days in dinoflagellate cultures from Norway (Dale 1977)). Although this stage is the link between dormancy and A. fundyense vegetative cell populations, no research is published on factors affecting planomeiocyte success.

\section{Environmental Excystment Factors: Oxygen, Temperature, Light}

Oxygen is the factor with the most direct effect on germination; germination will only occur under oxic conditions (Anderson et al. 1987). Cysts can, however, survive extended periods of anoxia and can germinate successfully once they are exposed to oxygen. The effects of other environmental factors on germination are more complex. Both warmer temperature and increased light enhance germination rates and 


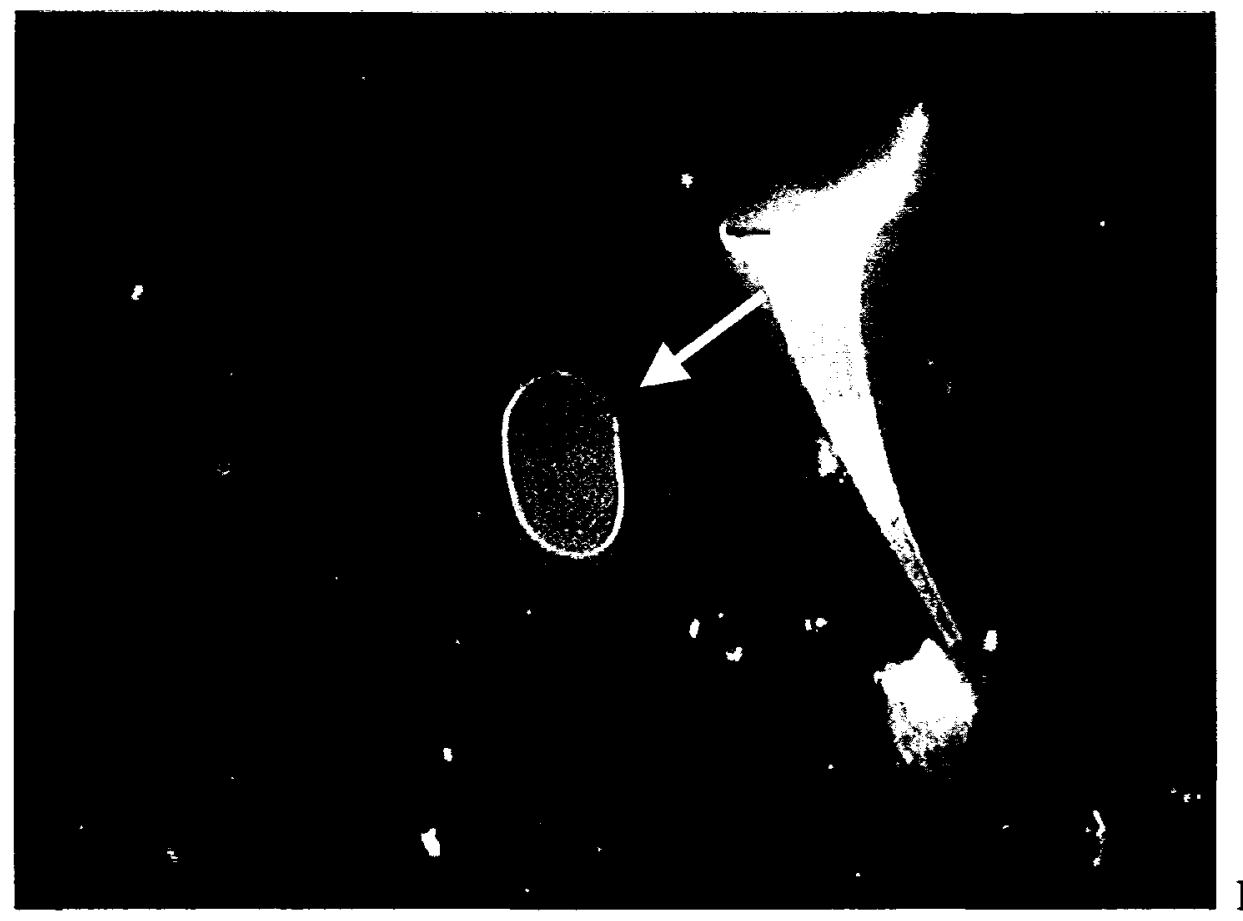

Figure 9 a

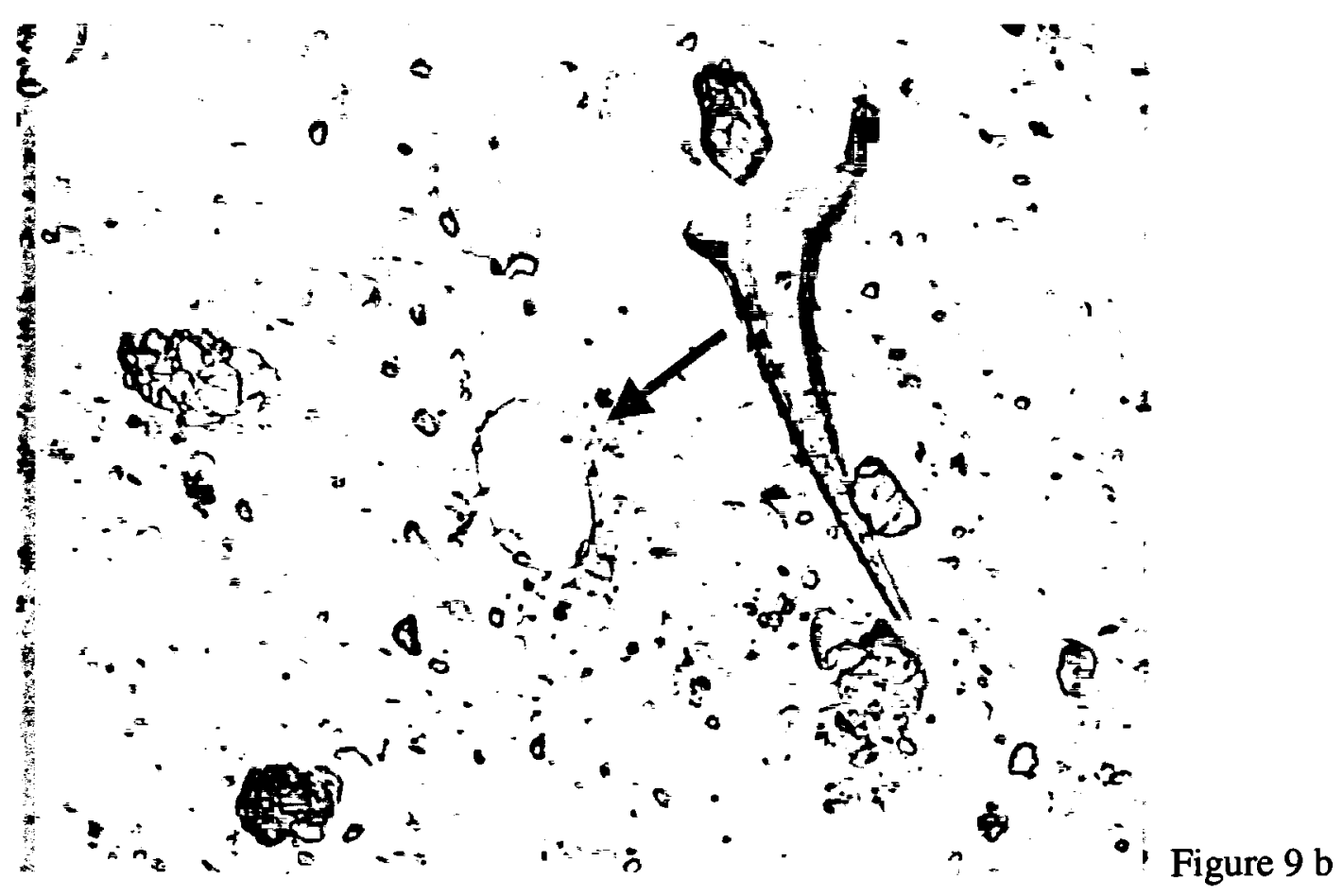

Figure 9. Photomicrographs (200x) of empty A. fundyense hypnozygote cyst wall with archeopyle clearly visible in a) epifluorescence and b) transmitted light. From April-May 2000 cruise, station 171 , near-bottom sample (63m). 
planomeiocyte success, although the literature reports some variation on the extent to which germination is affected (Anderson and Wall 1978; Anderson and Morel 1979; Anderson 1980; Anderson et al. 1983; Anderson and Keafer 1987). Variations may result from differences in experimental design, natural variation among $A$. fundyense populations, or both. Natural variability within $A$. fundyense species is probable, and therefore it may not be possible to determine an accurate estimate of the temperature required for germination of $A$. fundyense in general. What is clear is that germination will not occur unless ambient temperatures are above a threshold temperature and rates will increase as the temperature rises to an upper limit above which germination will not occur (Anderson 1998). Field observations in the Bay of Fundy indicated that cysts began to show signs of incipient germination (increase in Brownian motion) when temperatures rose above $5-6^{\circ} \mathrm{C}$ (White and Lewis 1982; Anderson et al. 1987). Laboratory observations of cysts isolated from a salt pond indicated that cysts did not show signs of germinating (autofluorescence in chlorophyll) until waters warmed to temperatures of $6-8^{\circ} \mathrm{C}$ (Anderson and Morel 1979). Anderson and Wall (1978), who defined excystment to be the full emergence of the planomeiocyte from the cyst wall, observed that excystment occurred when cultures were incubated at $16^{\circ} \mathrm{C}$. There is also evidence for an upper limit to the temperature for successful germination, at least in salt ponds in Massachusetts; germination resumed in the fall when temperatures fell below $\sim 18^{\circ} \mathrm{C}$ (Anderson and Wall 1978; Anderson and Morel 1979; Anderson 1998).

Anderson and Wall (1978) tested the effects of several environmental factors on germination. They saw no significant effects of light or nutrients on germination from different light or nutrient levels, although germinated planomeiocytes showed increased motility when germination occurred in light in a highly chelated medium. Later work by 
multiple authors has consistently shown that light does enhance germination (see Table 2 and references therein). Anderson and Keafer (1985) concluded that if temperatures are favorable then light is the next most important environmental factor affecting excystment. A. tamarense (= G. tamarensis) cysts isolated from Cape Ann germinated 8 times faster in a light treatment (Anderson et al. 1987). Germination in dark incubations occurred at extremely low rates $\left(0.018\right.$ day $\left.^{-1}\right)$, despite some "intense" light exposure that was required for experiment preparation. (Brief exposure to increased temperatures caused germination in cysts stored at $5^{\circ} \mathrm{C}$; whether brief exposure to light caused similar complications was not assessed (Anderson et al. 1987).) The germination rate of $G$. tamarensis in the light treatment was 0.14 day $^{-1}$ (Anderson et al. 1987). No germination of any dinoflagellate cysts (Alexandrium species were not included) from the Baltic and North Seas occurred in the dark over a study period of two weeks, while in light studies, germination of all cysts was usually completed in seven days (Nehring 1996). Despite earlier studies suggesting that light was not an important excystment cue, the preponderance of published results indicate that light does enhance germination and germination success. Results of published studies of dark excystment do not conclusively establish that Alexandrium can germinate successfully in the total absence of light, although there is indication that dark germination may occur at a slower rate (Anderson et al. 1987; Nehring 1996). Variation in results (Nehring 1996 versus Anderson et al. 1987, for example) is probably due to experimental methods, as the former author waited only two weeks to observe dark germination. There may also be differences in behaviors between species, strains and even individual cysts (Cullen, personal communication). 


\begin{tabular}{|c|c|c|}
\hline Reference & $\begin{array}{c}\text { Germination factors } \\
\text { examined }\end{array}$ & Conclusions \\
\hline \multirow{3}{*}{$\begin{array}{l}\text { Anderson and Wall } 1978 . \\
\text { Lab }\end{array}$} & Temperature & Temperature increase caused germination \\
\hline & Light & $\begin{array}{l}\text { No effect on germination rate. Light } \\
\text { increased motility of planomeiocytes. }\end{array}$ \\
\hline & Nutrients & $\begin{array}{l}\text { No effect on germination rate. Highly } \\
\text { chelated medium increased motility of } \\
\text { planomeiocytes }\end{array}$ \\
\hline $\begin{array}{l}\text { Anderson and Morel } 1979 . \\
\text { Lab and field. }\end{array}$ & Temperature & $\begin{array}{l}\text { Temperature increase (somewhere between } \\
6-9^{\circ} \mathrm{C} \text { in field, above } 5^{\circ} \mathrm{C} \text { in lab) initiated } \\
\text { germination. } \\
\text { Temperature decrease below } 20-22^{\circ} \mathrm{C} \text { in fall } \\
\text { triggered second excystment period. }\end{array}$ \\
\hline Anderson 1980. Lab. & Temperature & $\begin{array}{l}\text { Temperature increase (for cysts stored at } \\
5^{\circ} \mathrm{C} \text { ) or decrease (for cysts stored at } 22^{\circ} \mathrm{C} \text { ) } \\
\text { initiated germination }\end{array}$ \\
\hline \multirow[t]{2}{*}{ Anderson and Keafer 1985.} & Temperature & $\begin{array}{l}\text { Temperature increase triggers germination. } \\
\text { Lower temperature induces germination in } \\
\text { cysts from deeper locations. }\end{array}$ \\
\hline & Light & $\begin{array}{l}\text { Most important factor after temperature, } \\
\text { (citing Anderson, unpublished data) }\end{array}$ \\
\hline \multirow{2}{*}{$\begin{array}{l}\text { Anderson, Taylor, Armbrust } \\
\text { 1987. Lab. }\end{array}$} & Oxygen & Oxygen necessary to germinate \\
\hline & Light & $\begin{array}{l}\text { Germination occurred in dark ( } 0.018 / \text { day }) \text {, } \\
\text { light enhanced germination rate }\end{array}$ \\
\hline $\begin{array}{l}\text { Anderson and Keafer } 1987 . \\
\text { Lab. }\end{array}$ & $\begin{array}{l}\text { Endogenous clock in light } \\
\text { and warm temperatures }\end{array}$ & $\begin{array}{l}\text { Germination frequency followed seasonal } \\
\text { cycle, preferentially occurring between } \\
\text { December and August }\end{array}$ \\
\hline \multirow{2}{*}{$\begin{array}{l}\text { Nehring 1996. Lab. Mixed } \\
\text { dinoflagellates, no } \\
\text { Alexandrium. }\end{array}$} & Warm $\left(18^{\circ} \mathrm{C}\right)$ and Light & Germination within $2-7$ days \\
\hline & Cold $\left(4^{\circ} \mathrm{C}\right)$ and Dark & No germination in 2 weeks \\
\hline
\end{tabular}

Table 2. Summary of results from germination factor studies of Alexandrium. 


\section{Endogenous Clock}

Using cysts isolated from sediment cores taken from 60 and $160 \mathrm{~m}$ of water off of Cape Ann in the Western Gulf of Maine, Anderson and Keafer (1987) documented the first evidence of an endogenous clock in Alexandrium cysts. A bulk mud sample from a station offshore of Cape Ann (their station $29160 \mathrm{~m}$ deep) was stored in darkness at $2^{\circ} \mathrm{C}$ and subsampled at monthly intervals over the course of two years. Subsamples were taken and placed in culture medium at $15^{\circ} \mathrm{C}$ in a $14: 10$ hour light $\left(150 \mu \mathrm{Em}^{-2} \mathrm{~s}^{-1}\right)$ dark cycle to evaluate germination. Cysts preferentially excysted during the months from January to July, with no excystment in September and October (Anderson and Keafer 1987). The presence of an endogenous clock has been confirmed by recent work by Thompson et al. (2000). Endogenous clock-induced germination in darkness at cold temperatures has been tested as well and found to occur at low rates, although the methods for germination in darkness and germination in light are not identical in addition to the obvious difference in light level (Matrai, personal communication).

If an endogenous clock is driving Alexandrium excystment the importance of environmental factors are not necessarily insignificant; germination rates and planomeiocyte success are affected by light, temperature, and water chemistry (Anderson and Wall 1978; Anderson et al. 1987). Most studies documenting the endogenous clock have evaluated excystment readiness by the same methods as Anderson and Keafer (1987); a sediment sample containing cysts is held in long-term dark, cold storage and subsampled at some time interval. Subsamples are incubated in a 14:10 hr light dark regime at an elevated temperature $\left(\sim 15^{\circ} \mathrm{C}\right)$ and germination rates are recorded (Matrai, personal communication). Germination experiments in the darkness do give credence to 
the hypothesis that germination can occur in darkness triggered solely by the endogenous clock.

\section{Ecological Implications of Germination Factors and Deep Benthic Cysts}

The importance of light for germination success becomes a critical question when evaluating the potential for benthic cysts to initiate vegetative cell blooms. If light is necessary for successful germination, cysts on the bottom below the photic zone will not contribute directly to the spring bloom unless they are resuspended, as has been suggested by numerous authors (Anderson et al. 1983; Anderson, Taylor, and Armbrust 1987; Nehring 1996; Brown et al. 2001). If the bottom is within the photic zone, as it is in salt ponds and shallow estuaries, benthic cysts on the surface of the sediment will germinate and contribute to a perennial vegetative cell population. If germination in darkness can occur successfully, as recent unpublished studies may indicate, deep cyst beds can contribution to spring vegetative cell populations. The contribution that benthic cysts can make towards establishing a springtime vegetative cell population will depend on specific light levels and temperatures, and consequent germination rates.

Although the early division of planomeiocytes is beneficial for increasing vegetative cell concentrations, this tendency towards division within 24 hours of emergence may hinder rather than enhance a planomeiocyte cell's chance for success if that planomeiocyte cell excysted below the euphotic zone and must swim upward through darkness before it can photosynthesize (Nehring 1996). (Whether or not cysts germinating in darkness in laboratory studies divided as quickly after emergence as cysts germinating in light has not been assessed (Anderson, personal communication).) A long transit time between a deep benthic cyst bed and the photic zone also increases the 
chances of loss (e.g., grazing, advection). There is evidence that only a small portion of benthic cysts germinate each year, although many more are viable, even in the shallow, well-lit environment of a salt pond ( $<10 \%$ say Anderson and Keafer 1985; Martin and White 1988; Wyatt and Jenkinson 1997; Anderson et al. 1987; Brown et al. 2001). Anderson et al. (1983) summarized this issue by concluding: "the numerical abundance of cysts has little bearing on the magnitude of subsequent blooms." To my knowledge, the length of time a planomeiocyte or new vegetative cell can survive in darkness has never been evaluated; this datum would help constrain the depth from which germination might successfully occur. Because planomeiocytes contain significant starch reserves, they can presumably survive and possibly even divide in darkness. Due to the important implications of planomeiocyte survival in darkness, however, this needs to be verified.

\section{Benefits and Limitations of Alexandrium Research in Salt Ponds}

Salt ponds are extremely accessible for the study of Alexandrium, however, there are some significant obstacles to extrapolating what is learned in a salt pond to the more dynamic environment of continental shelf waters such as the Gulf of Maine. Perhaps the most significant differences between the Gulf of Maine and a salt pond are the much greater depths and currents in the gulf. In a salt pond all benthic cysts are exposed to vernal warming and light and are therefore able to photosynthesize upon germination. In the gulf, where light and vernal warming may not reach the bottom, benthic cysts may excyst at very low rates or may not excyst at all, and may or may not survive long enough to reach the euphotic zone. Researchers observing population dynamics in salt ponds have estimated that less than $10 \%$ of cysts germinate even in these shallow, well-lit environments (Anderson et al. 1983; Anderson and Keafer 1985). It seems likely that 
only a low percentage of the cysts in the Gulf of Maine that can germinate will do so. Currents in the gulf can greatly complicate Alexandrium ecology by dispersing and accumulating vegetative cells as well as hypnozygote cysts, possibly disconnecting the geography of vegetative bloom termination and initiation (see Figure 10). Such physical reworking is greatly limited in a salt pond.

There is evidence that strains of Alexandrium in salt ponds differ from those in deeper waters. Cyst sizes and temperature sensitivity of germination vary between cysts from Cape Cod salt ponds and from offshore of Cape Ann (Anderson et al. 1985; Anderson and Keafer 1985). Cysts from areas farther east have not been studied to the extent that Cape Cod salt pond and Cape Ann cysts have been, but variations among cysts from these different areas would be expected. Laboratory experiments and Cape Cod salt pond observations may or may not be applicable to the greater Gulf of Maine.

\section{Alexandrium and Paralytic Shellfish Poisoning in Gulf of Maine}

Paralytic shellfish poisoning has been documented in the Gulf of Maine and Bay of Fundy since 1889 , when the first deaths resulted from shellfish ingestion were reported (Ganong 1889). Alexandrium was not correlated with PSP toxicity until 1948 (Needler 1948), and not found to contain saxitoxin until 1963 (Prakash 1963). Wide scale monitoring for PSP in the Bay of Fundy started in 1945, and in the State of Maine in 1957, in response to two large PSP incidents in these areas in the Gulf of Maine (Bond 1975; Hurst 1975). Toxin has been detected in shellfish by the Maine monitoring program every year since its inception (Hurst 1979). In 1972 a wide scale PSP event in the Gulf of Maine was recorded following the transit of Tropical Storm Carrie, with Alexandrium densities on the order of $10^{6}$ cells per liter, enough to color the water red 


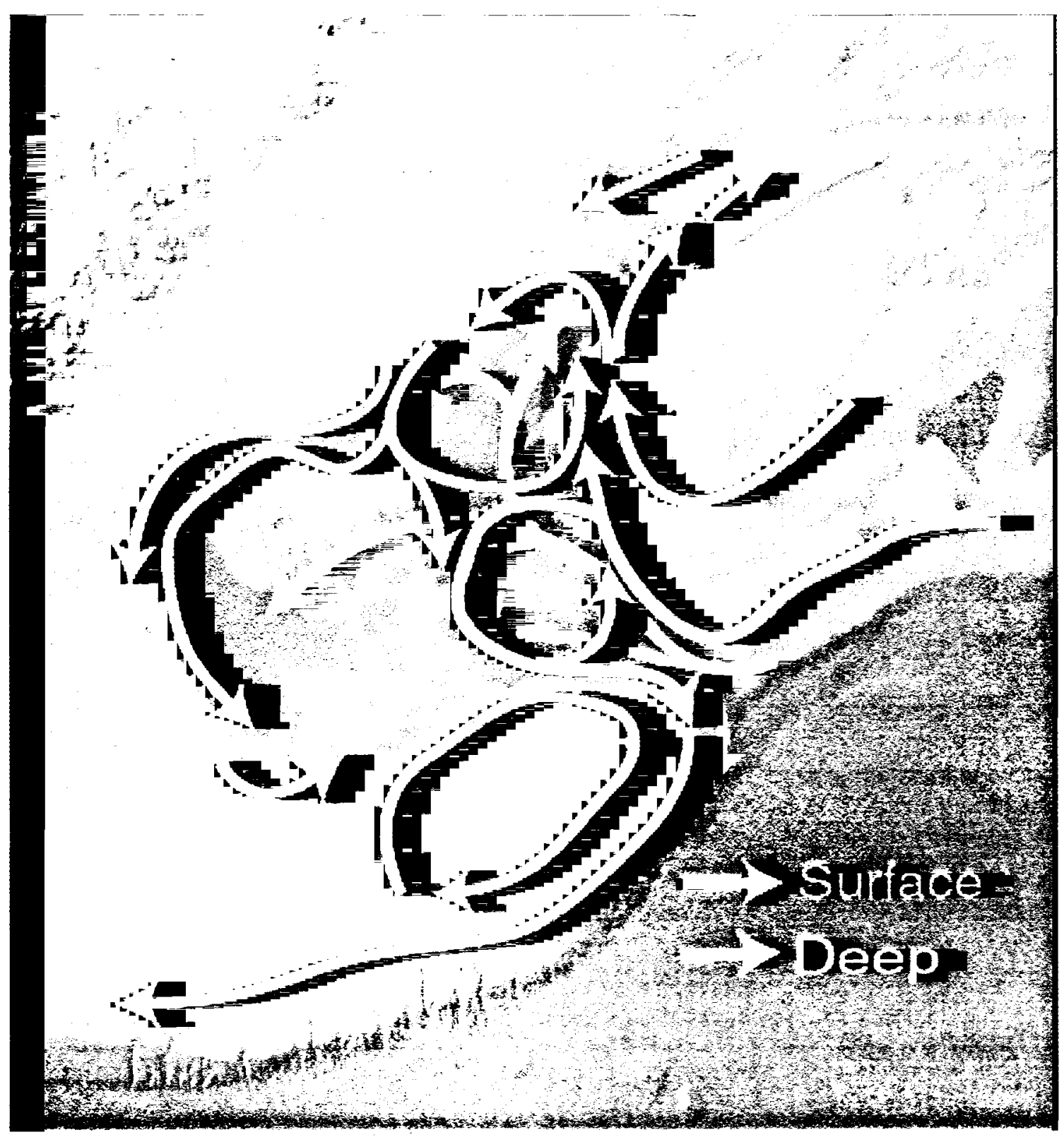

Figure 10. General summertime circulation in the Gulf of Maine (Pettigrew, unpublished). 
(Sasner et al. 1975). Expanded monitoring after 1975 also found yearly PSP events. One theory was that the cells of the blooms of 1972 formed cysts and thereby established perennial populations of Alexandrium in the western Gulf of Maine where it had not been found prior to 1972 (Hartwell 1975; Anderson and Wall 1978; Anderson et al. 1982b), although Townsend et al. (2001) argue otherwise. The apparent increasing frequency of PSP events since the 1972 incident and consequent losses in coastal states' shellfish fisheries led eventually to the establishment of the multi-institutional research program Ecology and Oceanography of Harmful Algal Blooms in the Gulf of Maine (ECOHABGOM), funded by the National Science Foundation and the National Oceanic and Atmospheric Administration of which this study is a part.

ECOHAB studies of Alexandrium vegetative cells in offshore waters found densities upwards of 4000 cells per liter in the Gulf of Maine in late spring and early summer of 1998 (Townsend et al. 2001). The bloom has been documented by large-scale ECOHAB samplings in June and July of 1998 and 2000, and is well correlated with the Eastern Maine Coastal Current (Pettigrew et al. 1998; Townsend et al. 2001) as well as with closures of shellfish beds to harvesting (Hurst 1979). Work is underway to determine what light and nutrient conditions correlate with maximum Alexandrium bloom densities. Townsend et al. (2001) proposed a light to nutrient ratio scheme for identifying waters with the potential of supporting larger blooms of Alexandrium. Little work has been done to determine where and how offshore blooms are initiated, or from where they originate. An earlier field season in 2000 attempted to constrain the timing and location of bloom initiation but failed to answer these questions conclusively as Alexandrium vegetative cells were already distributed throughout the Gulf of Maine (Townsend, unpublished data). The biological processes involved in bloom initiation are 
not well understood either and hinge on the over-wintering hypnozygote cyst stage of Alexandrium.

Lewis et al. (1979) completed the first survey of benthic Alexandrium hypnozygote cysts in the Gulf of Maine. They found benthic cysts to be widely distributed along the coast of Maine, although curiously absent within Frenchman and Penobscot Bays. Yentsch and Mague (1979) documented the occurrence of an Alexandrium hypnozygote cyst in a surface plankton sample. Benthic cyst surveys in the Bay of Fundy also revealed high densities of cysts, especially in the area north and east of Grand Manan Island (White and Lewis 1982). Vegetative cells were observed throughout the Bay, so the authors supposed that cyst formation also likely occurred throughout the bay, and physical processes (sediment dynamics) were responsible for concentrating them on the bottom northeast of Grand Manan Island. In the western Gulf of Maine, the Cape Ann area was sampled and found to contain widely distributed cysts close to shore (Anderson et al. 1982b). In 1997 a Gulf-wide benthic cyst sampling project was undertaken. Sediment samples were taken on a transect out to $\sim 120 \mathrm{~km}$ offshore. High densities of $A$. fundyense hypnozygote cysts were found in sample cores, especially in the area just south of Penobscot Bay and just south of Casco Bay (over 500 cysts/cubic cm of sediment) (see Figure 11). Cysts were found in highest densities in deep, offshore waters, generally greater than $80 \mathrm{~m}$ (see Figure 11). This positive relationship between cyst abundance and depth is likely due to multiple factors: sediment dynamics, as seen in the Bay of Fundy, as well as the biology and ecology of cyst formation and germination.

Aside from the single $A$. fundyense cyst found by Yentsch and Mague (1979) in the surface plankton tow at an unspecified location, one other study briefly looked for 


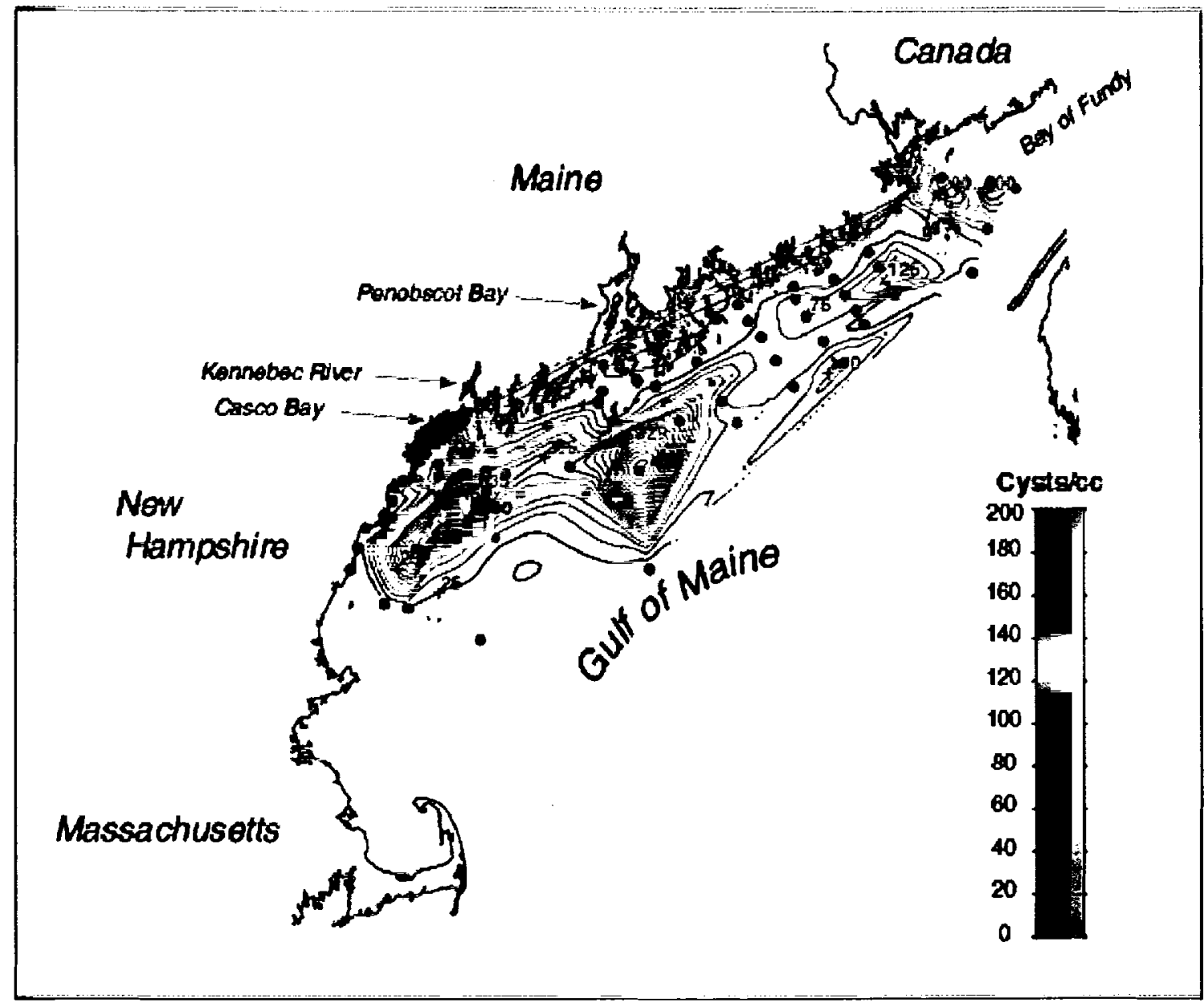

Figure 11. Map showing distribution of benthic $A$. fundyense cysts in the Gulf of Maine (Anderson, Keller, and Keafer unpublished data). 
cysts suspended in the western Gulf of Maine. Anderson and Keafer (1985) reported abundances of suspended cysts from $0-2000$ cysts $\mathrm{m}^{-3}$, with the vast majority of samples containing no cysts; in comparison to cyst concentrations on the bottom that were $3-4$ orders of magnitude greater. They concluded that the numbers of suspended cysts were insignificant to bloom inoculation.

Dinoflagellate cysts in suspension have received more attention in Europe. Reid (1978) found a wide variety and distribution of dinoflagellate cysts in the top $30 \mathrm{~m}$ of water around Great Britain and especially in the North Sea. Nehring (1996) took surface water samples as well as sediment samples in the German and Kiel Bights and enumerated dinoflagellate cysts within them. Dinoflagellate cysts ( 25 known species and 8 unidentified types) were present throughout the two study areas, with the relative abundance of each species consistent between water column and sediment. Live cysts accounted for roughly $25 \%$ of all cysts observed, with empty cyst walls comprising the other $75 \%$. There were greater densities of cysts (up to 75 per liter) as well as detritus in the water samples taken near shore than those from offshore, which was interpreted as evidence that cysts were resuspended and that resuspension is more likely in shallow water. Nehring (1996) commented that while only $10 \%$ of benthic cysts may excyst (citing Anderson et al. 1983) 100\% of cysts suspended in the water column may excyst, making these water column cysts 10 times as important as the benthic population of cysts.

As cysts are passive, silt-sized particles, cyst distribution patterns in the Gulf of Maine are likely controlled, at least in part, by sediment dynamics, as was concluded in the Bay of Fundy (White and Lewis 1982). Joint et al. (1997) in a study looking at PSP in the northeast United Kingdom also suggested that high benthic cyst concentrations 
might better reflect the depositional environment of the bottom than the source for spring bloom inoculum.

\section{Possible Scenarios for A. fundyense Population Initiation in the Gulf of Maine Before addressing the topic of initiation of $A$. fundyense populations, a distinction} must be made between population initiation and bloom formation. There are two processes that must take place to make an $A$. fundyense bloom possible: first, $A$. fundyense must be present in the phytoplankton community (population initiation), second, conditions (e.g., light, temperature, nutrients, grazers, competitors) must be favorable for a proliferation of $A$. fundyense to occur (bloom formation). Observations in salt ponds have shown that cyst germination does not lead directly to bloom density populations of $A$. fundyense as too few cysts germinate at any given time Anderson $e t$ al. 1983). Blooms do arise from the growth of vegetative cells germinated from cysts (there is no other source of vegetative cells in these isolated salt ponds), but the size of the bloom is not proportional to the inoculum, rather it depends on growth conditions subsequent to cyst germination. This discussion of hypnozygote cysts focuses on the first process, the establishment of $A$. fundyense in the plankton, rather than the perhaps more complicated question of what causes $A$. fundyense populations to bloom.

The possibility that $A$. fundyense motile cell populations persist through the winter months and initiate the spring bloom has not been definitively eliminated. However, hypnozygotes are a stage in sexual reproduction, not just a dormant stage (as opposed to the pellicle or temporary cysts, which is not sexual but purely resistant). A year-round vegetative population that undergoes sexual reproduction (and subsequent encystment) at irregular intervals is therefore unlikely as a long time scale explanation. Additionally, if 
hypnozygotes were not important to bloom initiation, coupling between the timing of the endogenous clock and the appearance of the vegetative cell population would not be expected. Development of blooms likely starts with germination from the encysted hypnozygote stage.

While we do know that cysts are present in sediments in the Gulf of Maine and that cysts likely initiate the spring vegetative cell population, we do not know where exactly germination occurs. If we knew where germination takes place we would know more about the environmental constraints on germination in the field. Three obvious sources exist: deep benthic cyst beds, shallow benthic cyst beds (within the euphotic zone), or suspended cysts in the water column. All three may contribute to initiation of the spring vegetative cell population to some extent. It may be possible to determine where the cysts that inoculate the spring vegetative cell population are, or to evaluate the relative contribution from these multiple cyst sources.

Benthic cysts, whether deep or shallow, may be prevented from germinating by anoxia or burial within the sediments (Anderson et al. 1987). What the effect of burial in sediment is on the success of the emerging planomeiocyte remains undetermined, although it is likely that there is a limit to the depth in sediment from which germination can occur (Anderson et al. 1982a). Bioturbation certainly affects vertical cyst distribution in sediments, but may have no net effect as cysts would be moved both up and down by bioturbation processes. Most germination studies sonify sediment samples, effectively removing all sediment from the mucilage that can surround cysts, prior to isolating cysts for experimentation, so no data is available on this subject (Anderson and Wall 1978; Anderson and Morel 1979; Anderson 1980; Nehring 1996). Oxygen has never been measured in sediment cores taken for the purpose of benthic cyst 
enumeration, but is thought to be present to the depth of 1 or possibly 2 centimeters in sediments in the Gulf of Maine (Watling, personal communication).

In addition to anoxia and potential adverse effects of burial, deep benthic cysts must germinate at low temperatures without light. Evidence for endogenous clock-driven germination in darkness supports the possibility that cysts in deep benthic cyst beds can germinate (Anderson et al. 1983). Recent work has shown no difference in germination rate between dark and light regimes at cold temperatures $\left(4-8^{\circ} \mathrm{C}\right)$ (Matrai, unpublished data). There is, however, enough conflicting evidence regarding germination of hypnozygote cysts in darkness that this subject warrants revisiting before conclusions can be drawn. Perhaps the discrepancies arise from the use of slightly different strains in different studies, or a refinement of techniques, but the reasons underlying the variability need to be determined in order to understand $A$. fundyense population dynamics.

Suspended cysts are a potential source for bloom inoculum. As Nehring (1996) pointed out, cysts in suspension are much more likely to germinate as they will have oxygen, higher temperatures and higher light than their benthic counterparts. Suspended cysts may or may not have ever settled to the bottom; the turbulence that would bring them up in the water column could also slow or prevent their settling. While turbulence is not unidirectional, there is a strong gradient in cyst concentration, the highest concentrations occurring in the sediment. Turbulence has the effect of weakening gradients, or moving cysts upward into the water column. In the Bay of Fundy, where cyst beds are not as deep as they are farther west and where tidal energy (and hence current shear stress at the bottom and turbulence) is high, suspended hypnozygote cysts are likely numerous. Cysts may be resuspended in the Bay of Fundy during winter when stratification is weakest and wind and wave energy can cause deep mixing and 
subsequent dispersal of suspended cysts. Alternatively, tidal currents in the Bay of Fundy may be strong enough to cause resuspension throughout the year. Between February and August, when the endogenous clock favors germination, the water column might contain enough cysts within and without the Bay of Fundy to initiate vegetative cell populations. Early germination of cysts could lead to high concentrations in later spring, even if the inoculating populations are subject to sup-optimal growth conditions and high loss rates.

Suspended cysts might also be found in the bottom nepheloid layer. Particulate matter settling from the surface concentrates at density discontinuities within the water column. The bottom nepheloid layer, a layer of increased suspended particulate matter lying near the bottom of the water column, is one such layer of increased particulate load. Townsend et al. (1992) described a bottom nepheloid layer in the Gulf of Maine as a layer of increased particulate matter, biomass, and increased biological activity extending $15-30 \mathrm{~m}$ up from the bottom. Although the bottom nepheloid layer is made up primarily of resuspended material, it may not be locally resuspended, but rather material resuspended elsewhere and advected along isopycnals, consequently being elevated off the bottom. In the Gulf of Maine the particulate layer maximum is separated from the bottom by a gap of $0.4-1 \mathrm{~m}$ (in the absence of any significant number of suspension feeders), indicating that processes other than resuspension, such as lateral advection, may be affecting the layer (Townsend et al. 1992). If $A$. fundyense blooms do indeed start from cysts in the water column those cysts might be found in the bottom nepheloid layer. While cysts suspended in the bottom nepheloid layer would not necessarily be exposed to optimum germination conditions, they would be free from possible interference of 
sediment and would be more easily entrained in vertical mixing than cysts resting in the bottom sediment.

\section{Objectives of This Study}

The primary objective of this study was to determine whether or not suspended $A$. fundyense hypnozygote cysts are present in the Gulf of Maine. A secondary objective was to evaluate the abundance of suspended cysts to determine if they might contribute to the initiation of spring vegetative cell populations. Previous study of $A$. fundyense hypnozygotes in the Gulf of Maine have almost exclusively investigated the abundance of cysts in sediment. Consideration of the dynamic currents in the gulf (see Figure 10) and the control environmental factors have on germination rate lead us to believe that suspended cysts would be widely distributed throughout the Gulf of Maine and would be essential to the understanding of the ecology of $A$. fundyense.

Given the difficulties benthic cysts face in order to successfully germinate, an investigation into the presence, and abundance, of suspended $A$. fundyense hypnozygote cysts is warranted. Ample evidence exists indicating that germination from deep cyst beds is problematic. Germination rates in darkness may be significantly lower than in light (Anderson et al. 1987; Matrai, unpublished data). Benthic cyst germination may be complicated due to the effects of burial (lack of oxygen, difficulties in escaping sediment). The long time it would take germling cells to reach the euphotic zone from the ocean floor increases the chance that these cells would be lost by advection, grazing, or some other means before they reach the surface. All these factors are mitigated for cysts suspended in the water column. 
If cysts are present in the water column, then the matter of their contribution to the spring vegetative population may be tentatively addressed, at least on a first order approximation. It would be valuable to know whether or not suspended cysts are worth further consideration as researchers work towards more detailed understanding of $A$. fundyense population dynamics. 


\section{METHODS}

\section{Shipboard}

To investigate the occurrence of planktonic $A$. fundyense hypnozygote cyst, water samples were collected from three cruises in the Gulf of Maine in 2000: February 20-25 on the $R / V$ Delaware II, April 24-May 2 and June 5-15 on the $R / V$ Cape Hatteras. Thirty liter water samples were taken from two depths: $2 \mathrm{~m}$ below the surface, $5 \mathrm{~m}$ above the bottom, and, in all months but June, the top of the bottom nepheloid layer as located by transmissometer. Station locations and numbers changed between each cruise.

In February, the rosette available could not accommodate $30 \mathrm{~L}$ Niskin bottles, so two casts were necessary at each station. First, a CTD package (CTD, transmissometer, fluorometer) on a rosette was deployed; $5 \mathrm{~L}$ Niskin bottles on the rosette were used to sample the water column at $20 \mathrm{~m}$ intervals for nutrients and chlorophyll a. A wire hydrocast was done after the CTD cast on a separate winch with 30L Niskin bottles; bottles were attached at the bottom of the wire, at the approximate depth of the top of the bottom nepheloid layer as indicated by the transmissometer on the CTD cast, and 2-3m below the surface. Wire angle was difficult to determine, and there was evident trouble with the winch meter, so bottle depths are not precisely known.

On the April and June cruises, a larger rosette was available and the $30 \mathrm{~L}$ bottles were deployed on the same cast as the CTD, transmissometer, fluorometer, nutrient, and chlorophyll sampling. This ensured greater accuracy of depth and hydrographic data relative to cyst data.

On all cruises, the actual volume sampled (between 25 and 29 liters) was recorded, then the water was poured through a 20 micrometer sieve, backwashed into a $50 \mathrm{ml}$ centrifuge tube using filtered seawater to a total volume of $45-48 \mathrm{ml} .2 .5 \mathrm{ml}$ of 
buffered formalin was added to the tube, the sample was inverted three times, then stored in a refrigerator.

\section{Laboratory}

The protocol followed in subsequent laboratory work was a modified version of that of Yamaguchi et al. (1995) as modified by Maureen Keller in 1997 for the benthic cyst study of that year (unpublished; see Table 3). After samples were centrifuged $10 \mathrm{ml}$ of supernatant were aspirated to allow for sonification in the original $50 \mathrm{ml}$ centrifuge tubes (this and all subsequent centrifugations were at $700 \mathrm{x} \mathrm{g}$ for 15 minutes at $18{ }^{\circ} \mathrm{C}$, as per protocol of Yamaguchi et al. 1995). Samples were sonified for 60 seconds with a Branson 250 probe-style sonifier at setting number 4 to free any debris from the mucilage surrounding the cysts (Keller protocol, unpublished). After sonification, samples were centrifuged again, and supernatant was aspirated until $5 \mathrm{ml}$ remained in the $50 \mathrm{ml}$ centrifuge tubes. At this point, samples were transferred into $15 \mathrm{ml}$ centrifuge tubes, using deionized distilled water (DDW). (The smaller tubes made careful aspiration of supernatant easier and allowed for more precise measurement at the small volumes involved.) Samples were centrifuged again, aspirated to $1 \mathrm{ml}$, then $10 \mathrm{ml}$ of methanol were added to each tube and the tubes were refrigerated.

After approximately 48 hours, samples were centrifuged again, the methanol supernatant was aspirated, and the sample was resuspended with $10 \mathrm{ml} \mathrm{DDW}$, and centrifuged again. Again, the supernatant was withdrawn. Two ml of filtered primulin stock solution $(0.067 \mathrm{~g}$ primulin powder $/ 50 \mathrm{ml} \mathrm{DDW})$ were added to each tube, samples were inverted three times and placed in the refrigerator. Primulin is a fluorochrome 


\begin{tabular}{|c|l|}
\hline Step & Procedure \\
\hline 1 & $\begin{array}{l}\text { Centrifuge, aspirate } 10 \mathrm{ml} \text { supernatant } \\
\text { NOTE: All centrifugations will be for } 15 \text { minutes at } 700 \times \mathrm{g}\end{array}$ \\
\hline 2 & Sonify for 1 minute at setting $4100 \%$, Branson 250 horn style sonifier \\
\hline 3 & Centrifuge, aspirate to $5 \mathrm{ml}$ remaining \\
\hline 4 & Transfer sample into $15 \mathrm{ml}$ centrifuge tube \\
\hline 5 & Centrifuge, aspirate to $1 \mathrm{ml}$ \\
\hline 6 & Add $10 \mathrm{ml}$ methanol, resuspend pellet, refrigerate for 2 days \\
\hline 7 & Centrifuge, aspirate methanol supernatant \\
\hline 8 & Resuspend pellet in $10 \mathrm{ml}$ distilled de-ionized water (DDW) \\
\hline 9 & Centrifuge, aspirate supernatant and discard \\
\hline 10 & Add 2 ml primulin solution, refrigerate for 2 hours \\
\hline 11 & Add $10 \mathrm{ml}$ DDW, agitate, centrifuge. \\
\hline 12 & Draw off supernatant, resuspend pellet in 10 ml DDW, centrifuge again \\
\hline 13 & Draw off supernatant \\
\hline 14 & Resuspend pellet with minimum mls of DDW to dilute particle concentration for counting \\
\hline
\end{tabular}

Table 3. A. fundyense hypnozygote cyst primulin staining protocol (after Keller 1997 , unpublished). 
compound that stains the cellulose wall, starches, and cell membranes in the cysts (Yamaguchi et al. 1995).

After two hours, $10 \mathrm{ml}$ DDW were added to each tube, samples were inverted and centrifuged. Supernatant was aspirated and samples were resuspended in $10 \mathrm{ml}$ DDW and centrifuged again. Supernatant was withdrawn for the last time, the sample was resuspended in 1-5 $\mathrm{ml} \mathrm{DDW}$, depending on the amount of particulate material each contained. Each sample was counted in its entirety, $1 \mathrm{ml}$ at a time in a Sedgwick-Rafter counting cell with a Nikon Optiphot-2 epifluorescence microscope using an excitation 330-380 nm filter. Identification was verified by examination under transmitted light.

Final cyst concentrations were determined relative to the original seawater volume sampled at sea. Cyst concentrations are reported as cysts $\mathrm{m}^{-3}$ to avoid having to report partial cysts (for example, 2 cysts counted in a $30 \mathrm{~L}$ sample would represent 0.07 cysts $\mathrm{L}^{-1}$, or, more sensibly, 67 cysts $\mathrm{m}^{-3}$ ).

Although intact $A$. fundyense cysts were the primary targets of counting, empty $A$. fundyense cysts were also enumerated. These were likely both dead cysts and the empty cyst walls left behind by germinating planomeiocytes. In most cases it was impossible to determine which, as observation of the archeopyle was only possible if the cyst wall was oriented optimally in the Sedgwick-Rafter counting cell. The reported abundances of empty $A$. fundyense cysts should be regarded as minimum densities, as the protocol and counting did not specifically address empty cysts.

A note on sonification. As this protocol was originally designed for evaluating cyst densities from sediment samples and we were adapting it for water samples it was unclear whether sonification would be necessary. The first three samples prepared were not sonified. In the first $1 \mathrm{ml}$ of stained sample examined under the microscope one cyst was 
found, with no mucus associated with it. Aggregates of sediment were also observed with something stained and fluorescing in the middle that might or might not have been an $A$. fundyense cyst, but the sediment precluded a positive identification. After these observations, a sonification step was included in the protocol.

The original protocol called for a sieving step after sonification. This step was omitted from the suspended cyst protocol as the detrital load was very low for most samples and the risk of losing cysts in sieving seemed to be greater than the benefits of removing extraneous particles.

Protocol for vegetative cell subsamples of February surface samples. February surface samples were subsampled for vegetative $A$. fundyense cell counts. Five $\mathrm{ml}$ subsamples were taken from the approximately $48 \mathrm{ml}$ of concentrated surface samples (see protocol in Townsend et al. 2001). Although these subsamples were only $5 \mathrm{ml}$, they represented approximately 2 liters, the usual sample size for $A$. fundyense vegetative cell counts. The protocol followed for vegetative cell counts requires samples to be mounted on slides on the filter on which they were prepared. This made cyst counts of these samples impossible, however, the remaining portion of the original surface samples were prepared following the cyst protocol and counted. 


\section{RESULTS}

Cysts were present in the water column in February, April, and June, with concentrations ranging up to 8000 cysts $\mathrm{m}^{-3}$ (see Tables 4 and 5 for summary). Empty cysts were also present in the water column in all months sampled. As sampling density and location varied between cruises, comparisons between the three cruise data sets must be made with caution. All cruises occurred during neap tidal periods (exact moon phase is given after each cruise date).

\section{February 20-25, R/V Delaware II (Full Moon Feb 19, New Moon March 6)}

The February cruise was designed to sample bacteria in the Bay of Fundy (Juliette Rooney-Varga) and zooplankton on a transect from coastal Maine to Georges Bank (Ted Durbin). Hence, spatial coverage for cyst sampling was spotty at best. Little can be concluded about the horizontal distribution of cysts during this month in the Gulf of Maine.

Cysts were present at all three depths sampled in February: surface, top of the bottom nepheloid layer, and near bottom (see Figure 12a and b). The distribution of cysts with depth varied between stations, but highest concentrations were generally found in the near bottom sample. February was the only month in which surface samples contained cysts; six of the ten surface samples contained cysts (see Table 5).

Empty cysts were present at all depths below the surface at all stations; stations 10 and 11 were the only two stations with no empty cysts at the surface (see Figure 13a and b). Empty cyst vertical distributions followed two patterns: virtually no change with depth (stations $5,8,10,13$ ) or an increase with depth (stations $4,6,7,9,11,12$ ). 

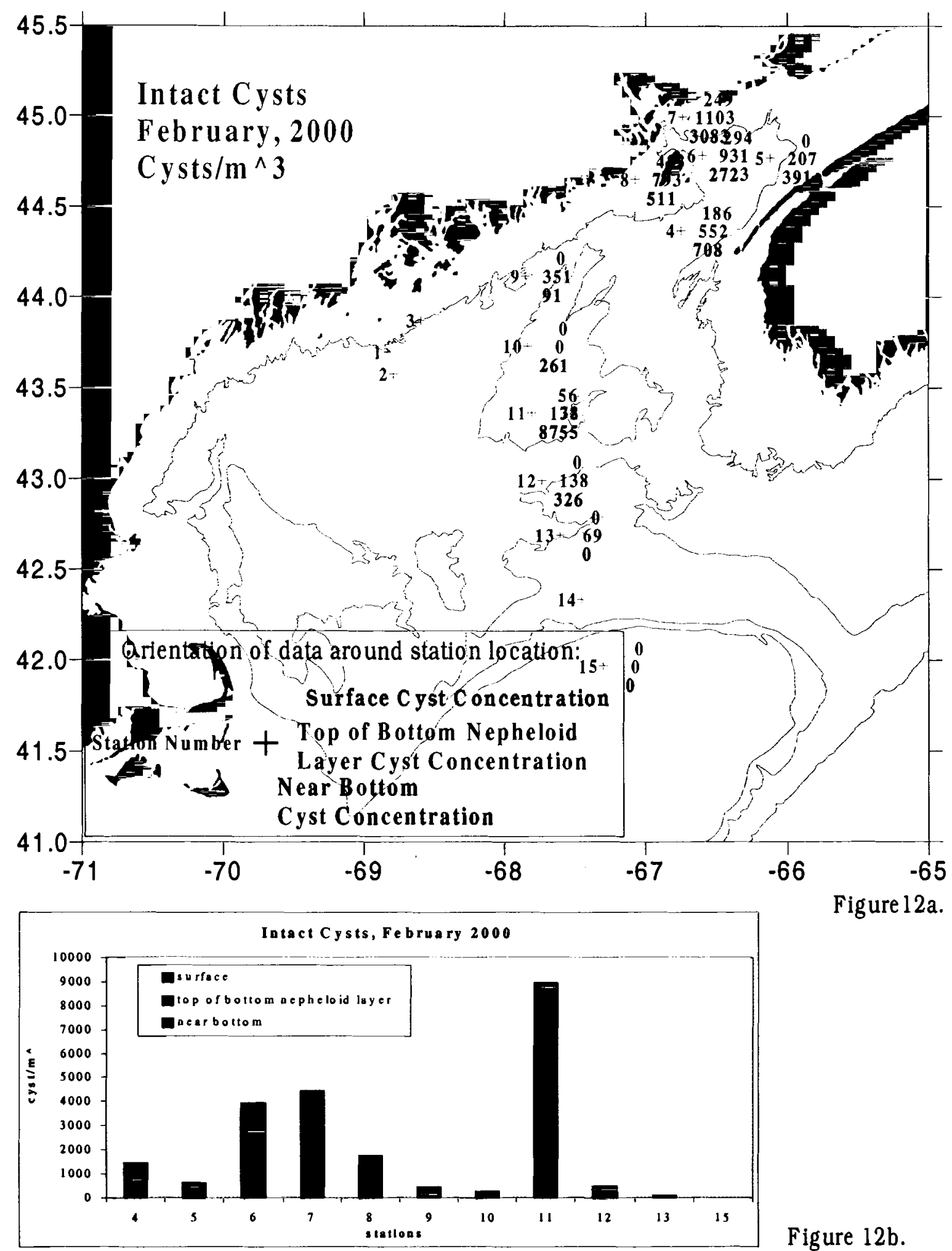

Figure 12b.

Figure 12. Intact cy sts, February 2000. a) show s station locations and cyst concentrations. $100 \mathrm{~m}$ and $200 \mathrm{~m}$ Isobaths indicated. b) show s bar graph of total intact cy sts at each station with contributions from each level. 

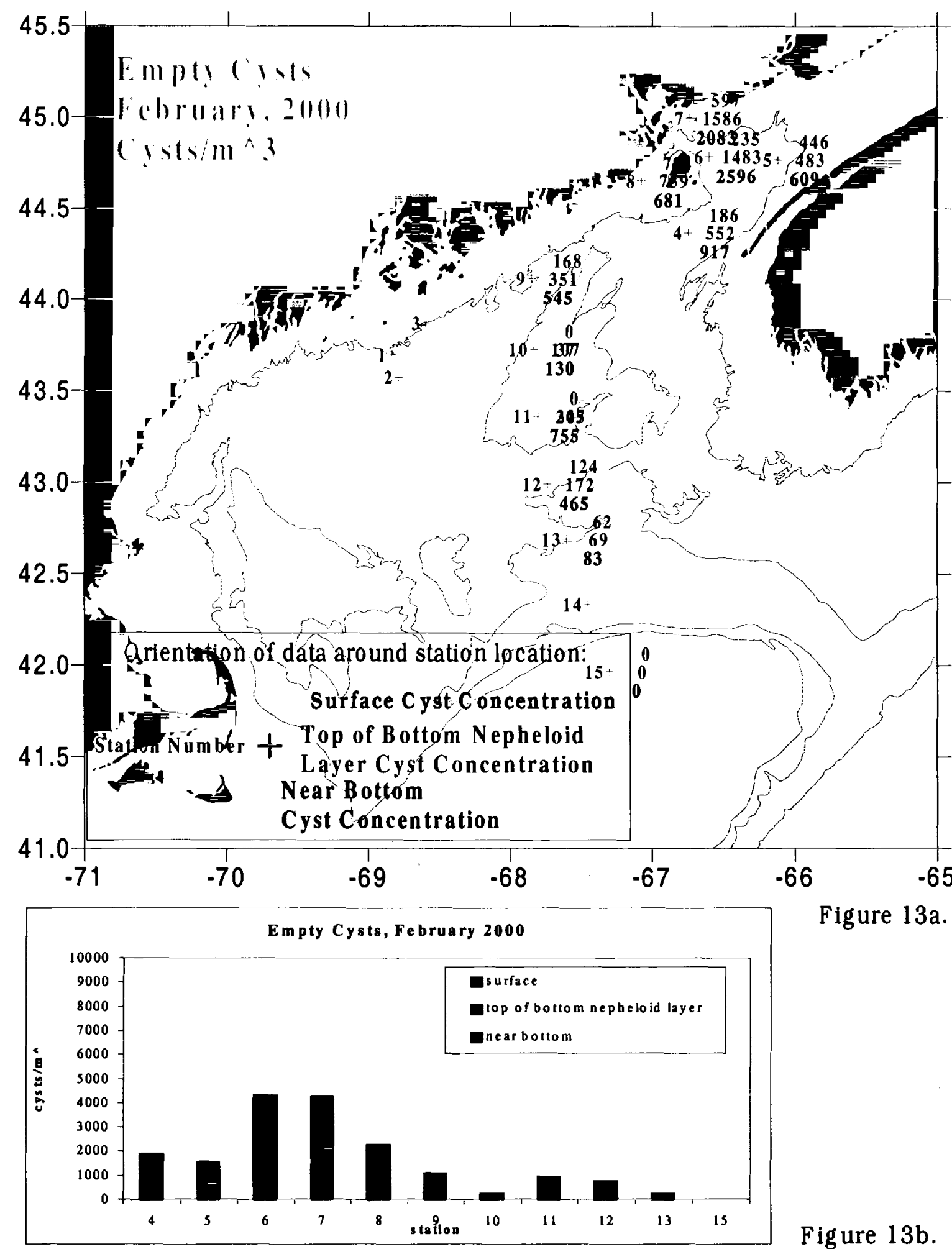

Figure 13a.

Figure 13b.

Figure 13. Empty cysts, February 2000. a) shows station locations and cyst concentrations. $100 \mathrm{~m}$ and $200 \mathrm{~m}$ isobaths indicated. b) show s bar graph of total empty cy sts at each station with contributions from each level. 
Although the difference was small, station 8 had the highest empty cyst density at the surface and least at the bottom; station 8 was one of the stations where the highest concentration of cysts occurred at the top of the bottom nepheloid layer.

During cyst counts, microscope observations were made of cysts with their internal contents withdrawn from the cyst wall and which showed strong red autofluorescence under epifluorescent light. Both are signs of imminent germination, or of recent cyst formation. These were a very small fraction of total cysts observed in February samples (19 of the 575 total cysts observed (3\%), in 10 different near bottom and top of bottom nepheloid layer samples from 6 stations). The autofluorescent cysts made up between 2 and $50 \%$ of the cysts in the samples in which they were found. Although the density of these autofluorescent cysts was low, their occurrence is very interesting, especially in light of the decrease in cyst densities observed in April (see April results and discussion following).

Vegetative cells were found in surface samples from February (see Figure 14). Their densities were very low relative to summer abundances. Conclusions that might be drawn from these data are considerably weakened by the thin spatial coverage of samples and the lack of duplicate samples. Despite the limited sampling, this is still the first documentation of vegetative cell population of A. fundyense in winter months in the Gulf of Maine.

\section{April 24-May 2, R/V Cape Hatteras (Full Moon April 18, New Moon May 4)}

The April-May cruise (henceforth referred to as the April cruise) was the first broad scale survey of the ECOHAB-GOM cruise season and as such included many more stations than were sampled during the February cruise. This increased sampling 


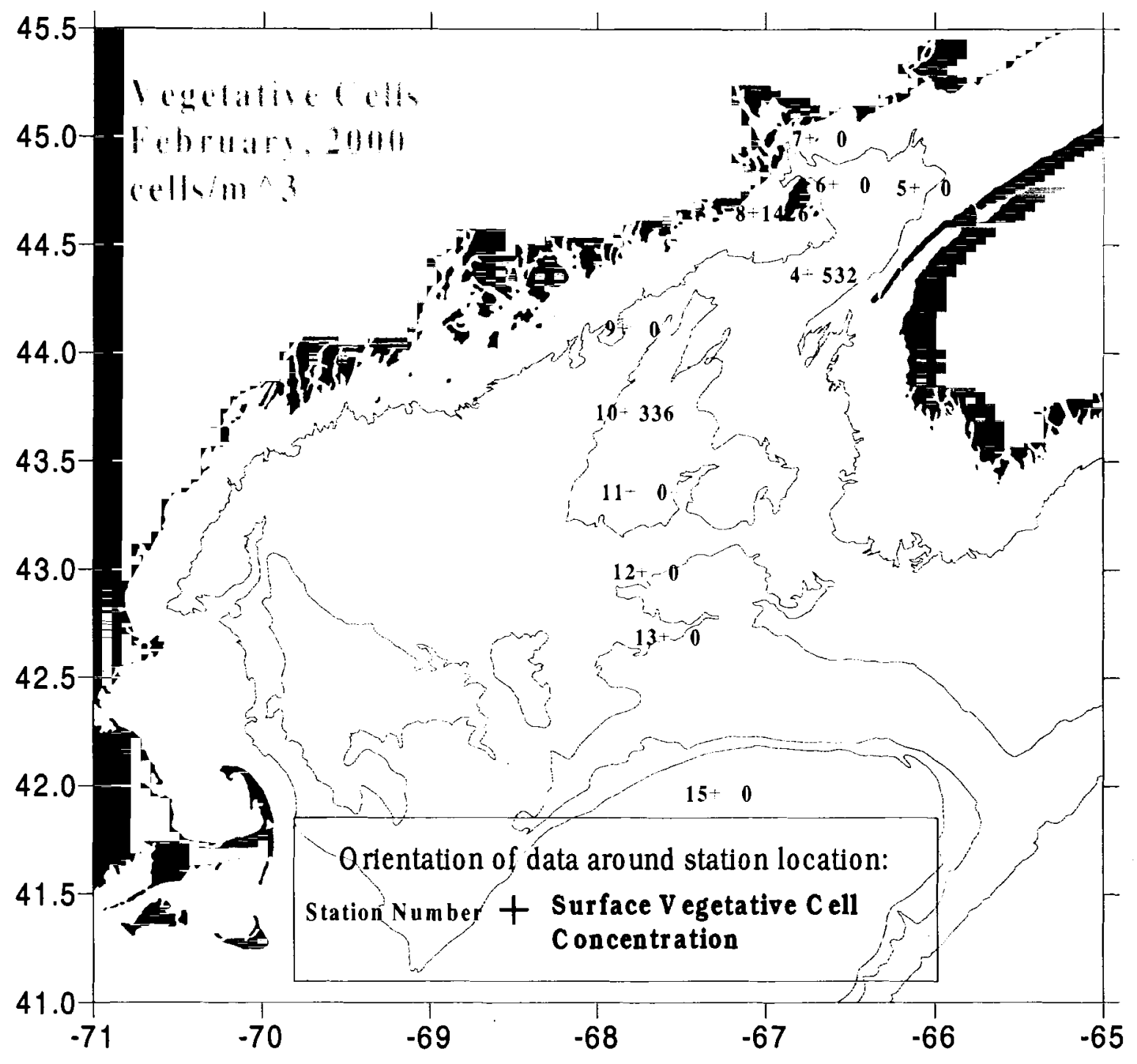

Figure 14. V egetative cells, February 2000. Figure shows station locations and vegetative cell concentrations. $100 \mathrm{~m}$ and $200 \mathrm{~m}$ isobaths draw $\mathrm{n}$. Counts reported in cells per cubic meter for consistency with cysy counts. 
area revealed widely distributed cysts through out the Gulf of Maine, from the Bay of Fundy to the Western Gulf of Maine (see Figure $15 \mathrm{a}$ and $\mathrm{b}$ ).

One distinct difference between April and February cyst data is that no surface April sample examined had any intact cysts or any empty cyst walls (see Figure 15 a and $\mathrm{b}$ and Figure $16 \mathrm{a}$ and $\mathrm{b})$. Some seasonal stratification develops in the Gulf of Maine in April, but vegetative cell densities were still low (Townsend, unpublished data). It seems likely that stratification would prevent introduction of cysts to surface waters by vertical mixing, and the low vegetative cell population would preclude formation of cysts this early in the year. These two factors likely explain the absence of cysts, intact or empty, in surface waters.

A total of 12 autofluorescent cysts were observed in 8 samples from 7 stations visited in April. All but two of these autofluorescent cysts came from near bottom samples. Because the total number of cysts counted in April samples was only 55, the autofluorescent fraction was over $20 \%$, a large increase from the $3 \%$ seen in February. Again, these percentages and trends are at best gross analyses of this data, useful only in making rough comparisons between months.

\section{June 5 -15, R/V Cape Hatteras (New Moon June 2, Full Moon June 16)}

The June cruise data differed from that of earlier months in that the top of the bottom nepheloid layer was not sampled. No surface samples counted contained cysts. Of the bottom samples, far more of the June samples had intact cysts than of the April samples; 20 of $28(71 \%)$ near bottom samples had cysts in June, while only 11 of 32 (34\%) near bottom samples had cysts in April (see Figure 17 a and Table 4). This trend likely results from the formation of the new cysts observed in the water column (see 


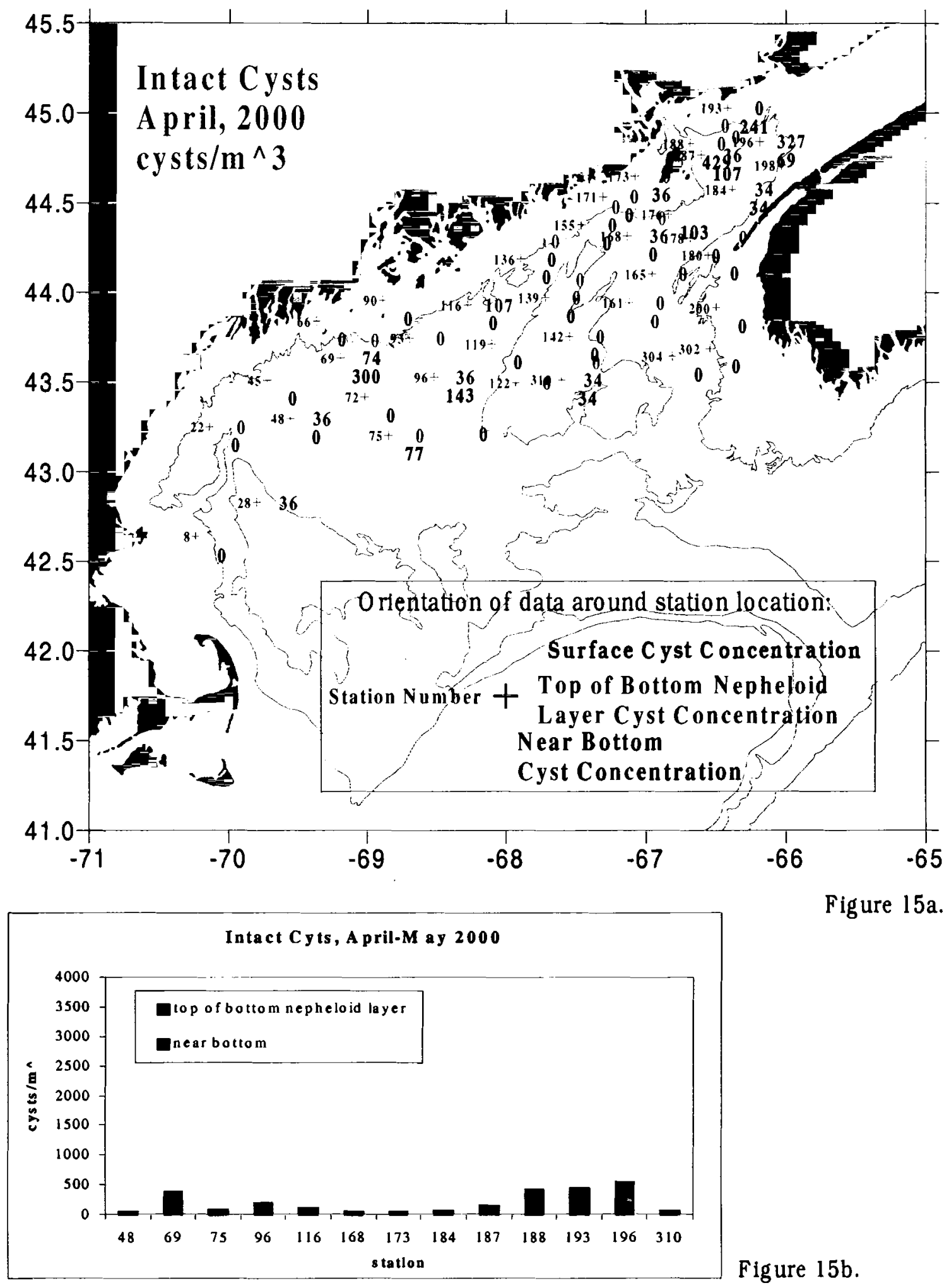

Figure 15. Intact cysts, A pril-M ay 2000. a) show s station locations and cyst concentrations. $100 \mathrm{~m}$ and $200 \mathrm{~m}$ isobaths indicated. b) show sar graph of total intact cysts at stations with near bottom and top of bottom nepheloid layer non-zero data. 

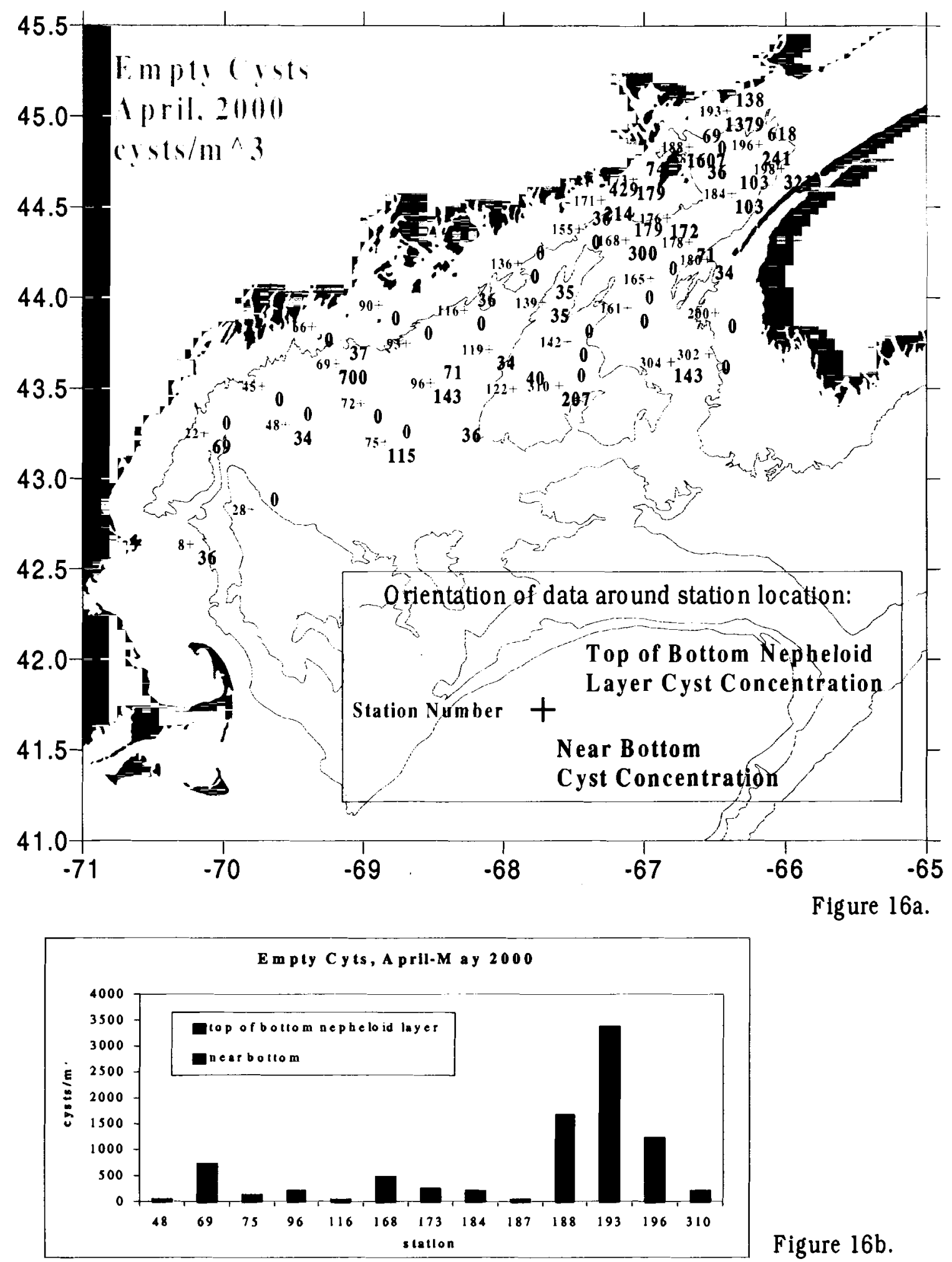

Figure 16b.

Figure 16. Empty cysts, A pril-M ay 2000. a) show s station locations and cyst concentrations. $100 \mathrm{~m}$ and $200 \mathrm{~m}$ isobaths indicated. b) show s bar graph of total empty cysts at station with near-bottom and top of bottom nepheloid layer non-zero data. 

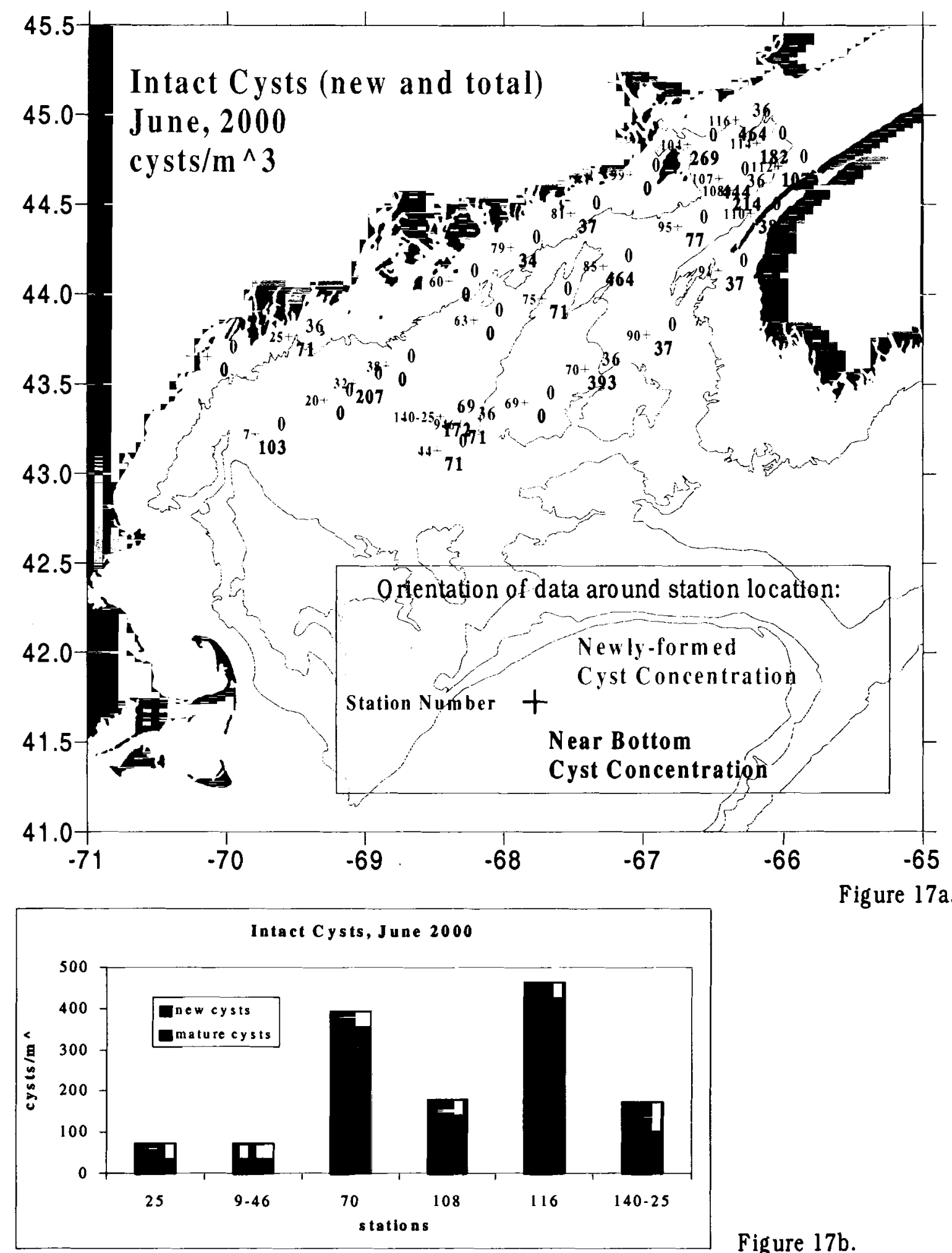

Figure 17b.

Figure 17. Intact cysts, June 2000. a) show s station locations and cyst concentrations. $100 \mathrm{~m}$ and $200 \mathrm{~m}$ isobaths indicated. b) show s bar graph illustrating contribution of new and mature cysts to total cyst counts for stations with both new and mature cysts. 
Figure $17 \mathrm{~b}$ ) rather than increased resuspension of benthic cysts; average tidal energy from the April cruise to the June cruise should be the same, and the wind experienced by both cruises is similar. New cyst formation in June is also consistent with observations made in salt ponds; new cysts began accumulating on the bottom before the peak in vegetative cell densities in the water column (Anderson et al. 1983).

New cysts are recognizable because they are entirely filled with starch grains, and appear dark under transmitted light (see Figures 5 and 6). Their shape sometimes varies from the typical capsule-like form of the more mature cyst. Identifications were made chiefly by physical resemblance to photomicrographs of new cysts kindly furnished to me by D. M. Anderson. Of the 109 cysts counted from June samples, 18 showed evidence of recent formation, which is greater than $15 \%$ of the total cysts.

Autofluorescent cysts were also counted in the June samples. Their abundance was lower than observed in April, which agrees with previous endogenous clock germination experiments that have shown that germination begins in February and ends in June, with most germination occurring in April and May (Anderson and Keafer 1987; Thompson et al. 2000).

The highest concentration of empty cysts was found well outside of the Bay of Fundy at station 85 (see Figure 18). Concentrations of empty cysts in the vicinity of Grand Manan Island and the Bay of Fundy were lower in April than February by a factor of four or five. Several stations in the gulf proper in April had no empty cysts; no nearbottom samples from February lacked empty cysts. 


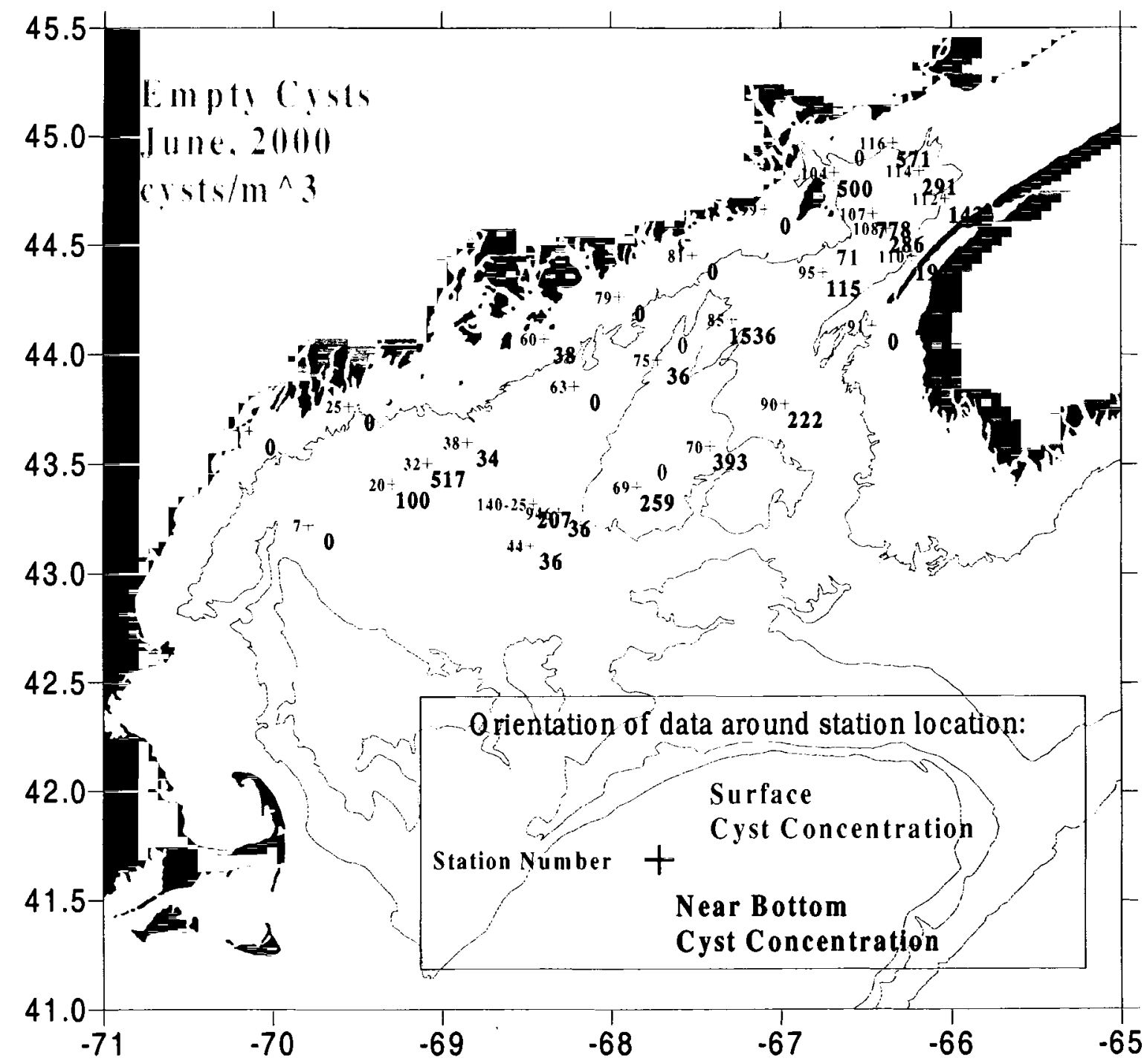

Figure 18. Empty cysts, June 2000. Figure show s station locations and cy st concentrations. $100 \mathrm{~m}$ and $200 \mathrm{~m}$ isobaths indicated. 


\section{Microscope Observations}

Mature $A$. fundyense hypnozygote cysts were relatively easy to identify by appearance and characteristic shape and size range. Much more variation exists in the morphology of new cysts, especially in size and shape (observations of new cysts supplied by WHOI). Two alternative cells posed challenges to identification: cells that in transmitted light resembled $A$. fundyense cysts in shape and appearance but in epifluorescent light appeared opaque and lacked an eyespot (see Figures 19-22), and cells that resembled $A$. fundyense cysts in all ways but were shorter $(35-40 \mu \mathrm{m}$ long) than the published ranges (43-72 $\mu \mathrm{m})$ for $A$. fundyense cyst lengths (see Figure 23). (Figure 19 shows both a "normal" A. fundyense cyst and a cyst lacking an eyespot; Figure 20 shows a higher magnification of the cyst lacking an eyespot. Figure 21 shows a new cyst next to a cyst lacking an eyespot.) These cyst types were occasionally very numerous (88 cysts lacking an eyespot were counted in the bottom sample from station 25), and often as numerous as $A$. fundyense cysts. These similar looking cysts were not counted towards A. fundyense cyst abundances. 


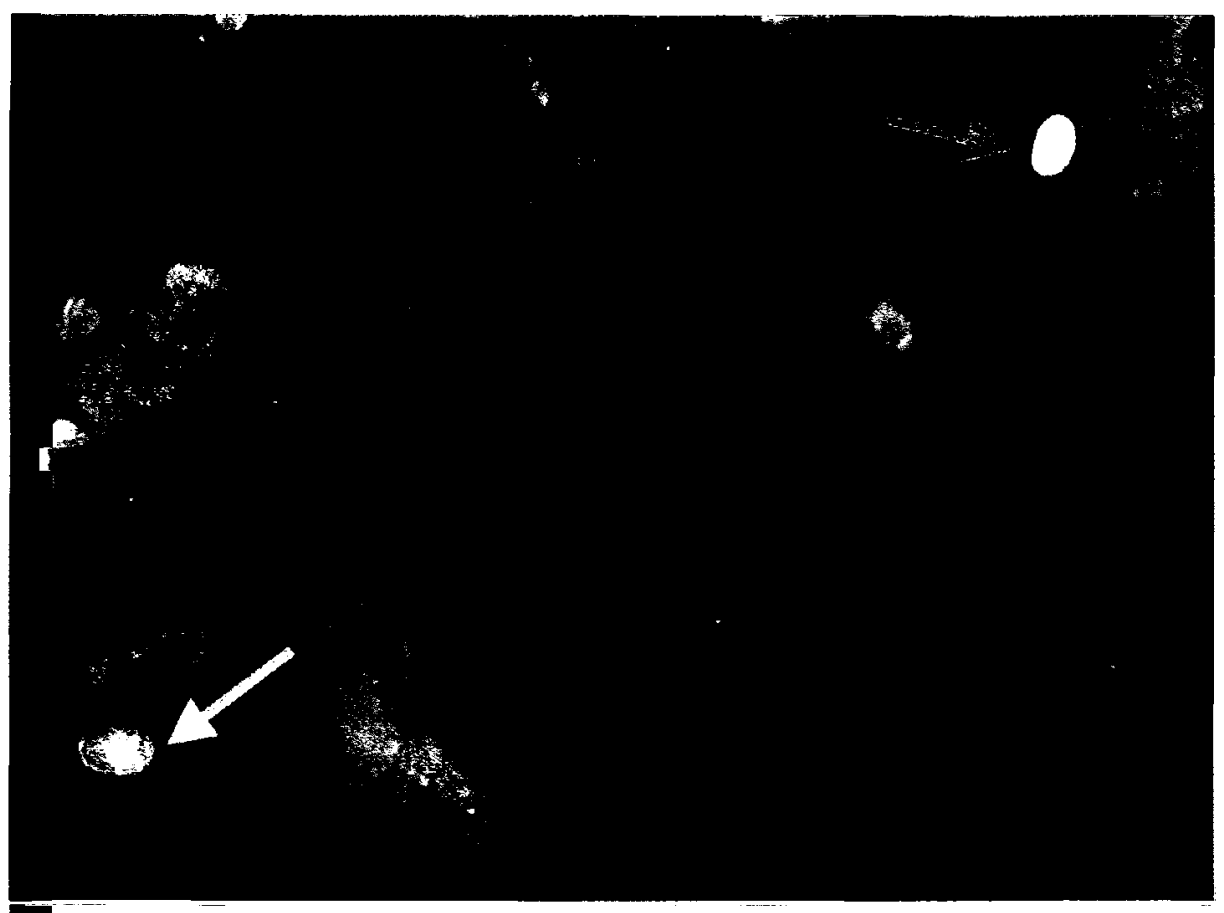

Figure 19 a

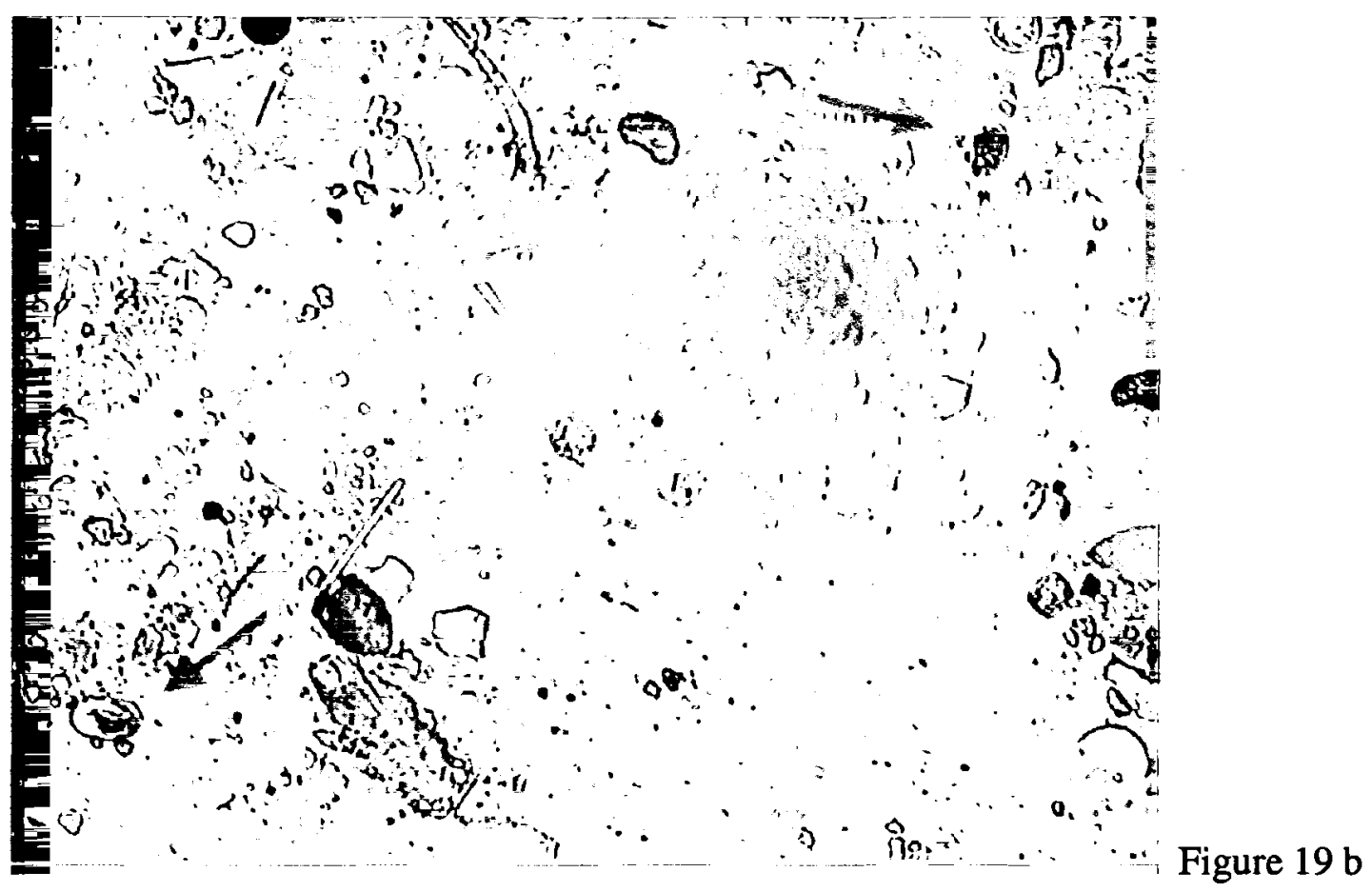

Figure 19. Photomicrographs (100x) of two cysts: a "normal-looking" A. fundyense hypnozygote cyst (red arrow) and a cyst that lacks an eyespot (blue arrow) in a) epifluorescence and b) transmitted light. From June 2000, station 69, near-bottom sample $(240 \mathrm{~m})$. 


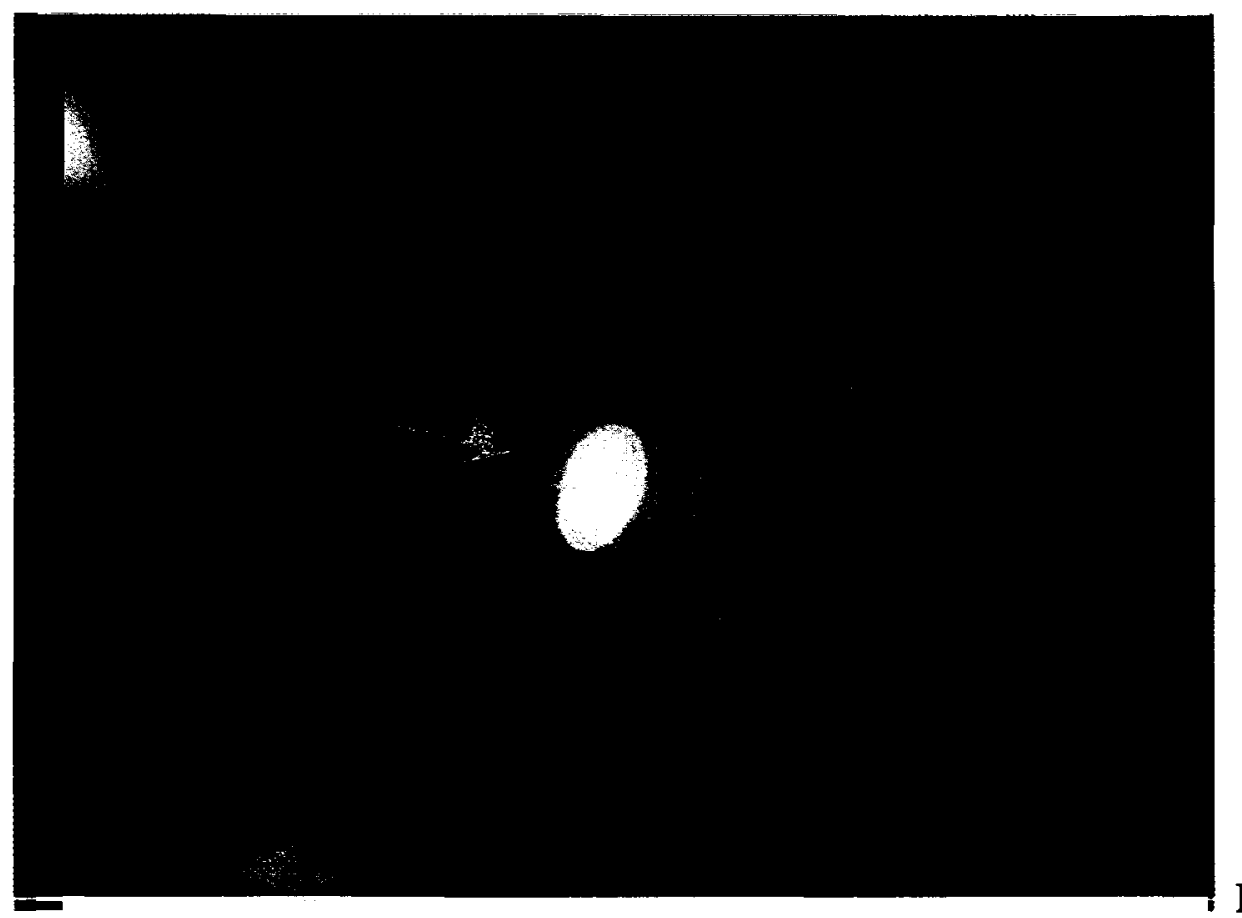

Figure 20 a

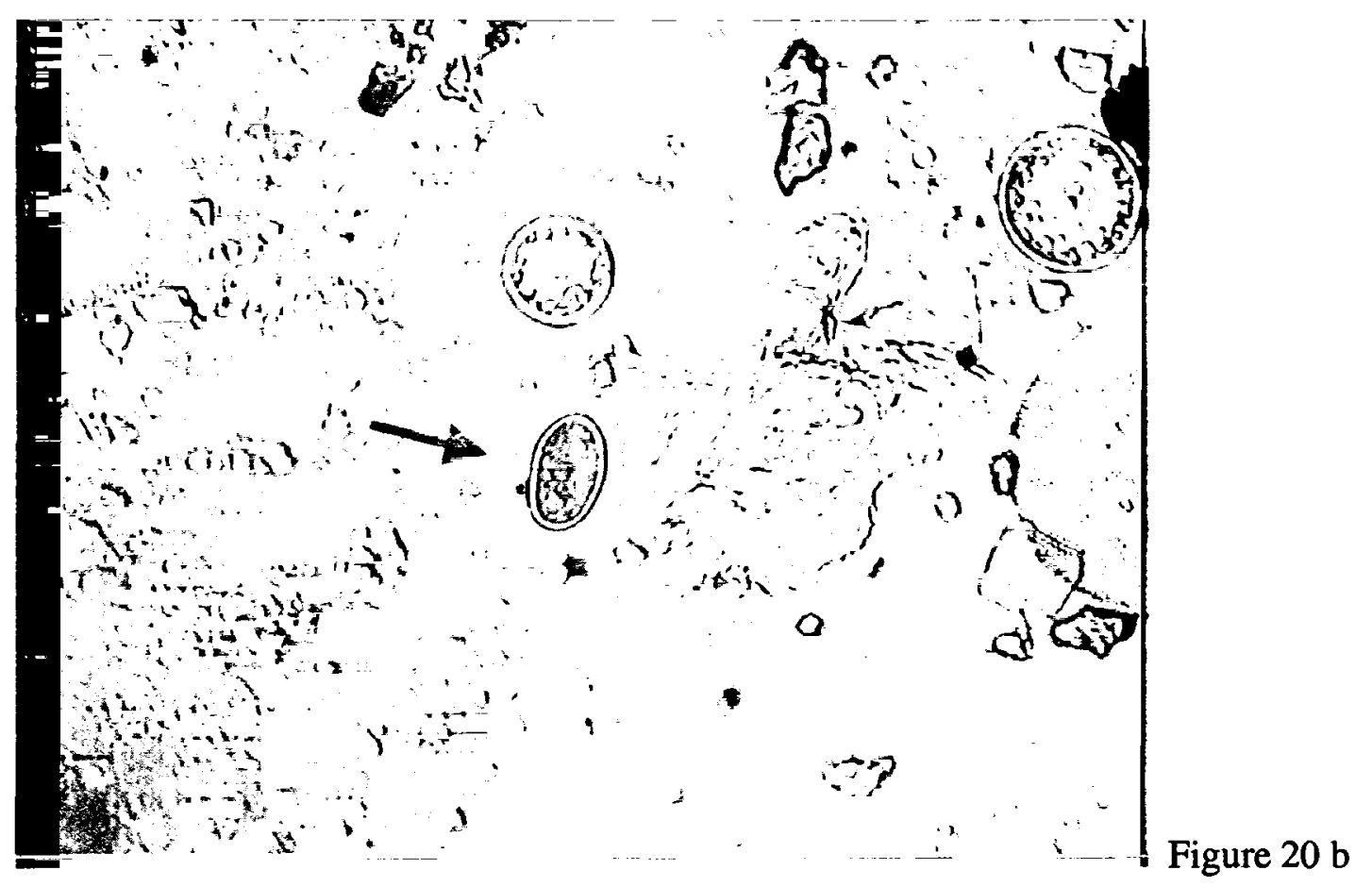

Figure 20. Photomicrographs (200x) of cyst without an eyespot (blue arrow) from Figure 21 in a) epifluorescence and b) transmitted light. From June 2000, station 69, nearbottom sample $(240 \mathrm{~m})$. 


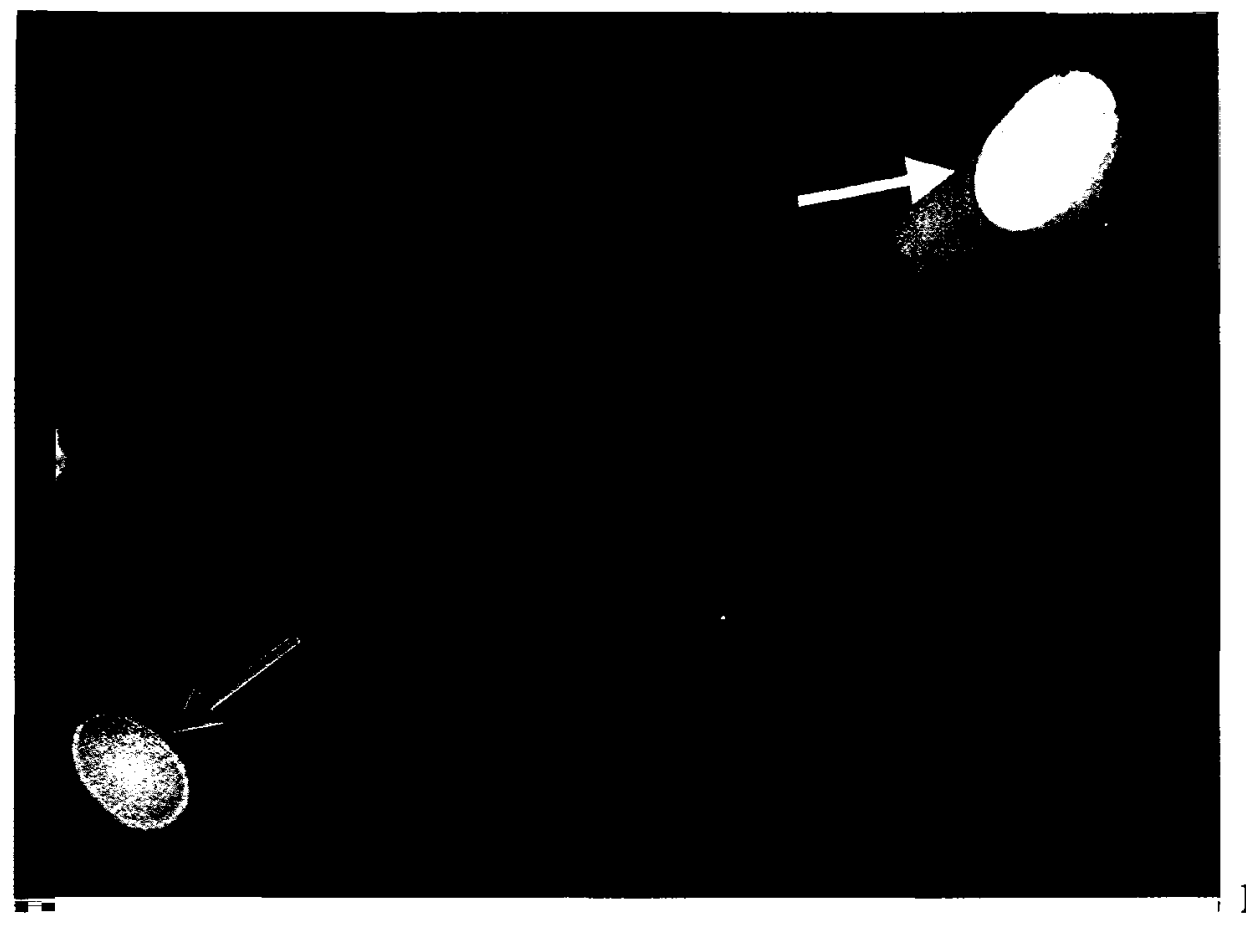

Figure 21 a

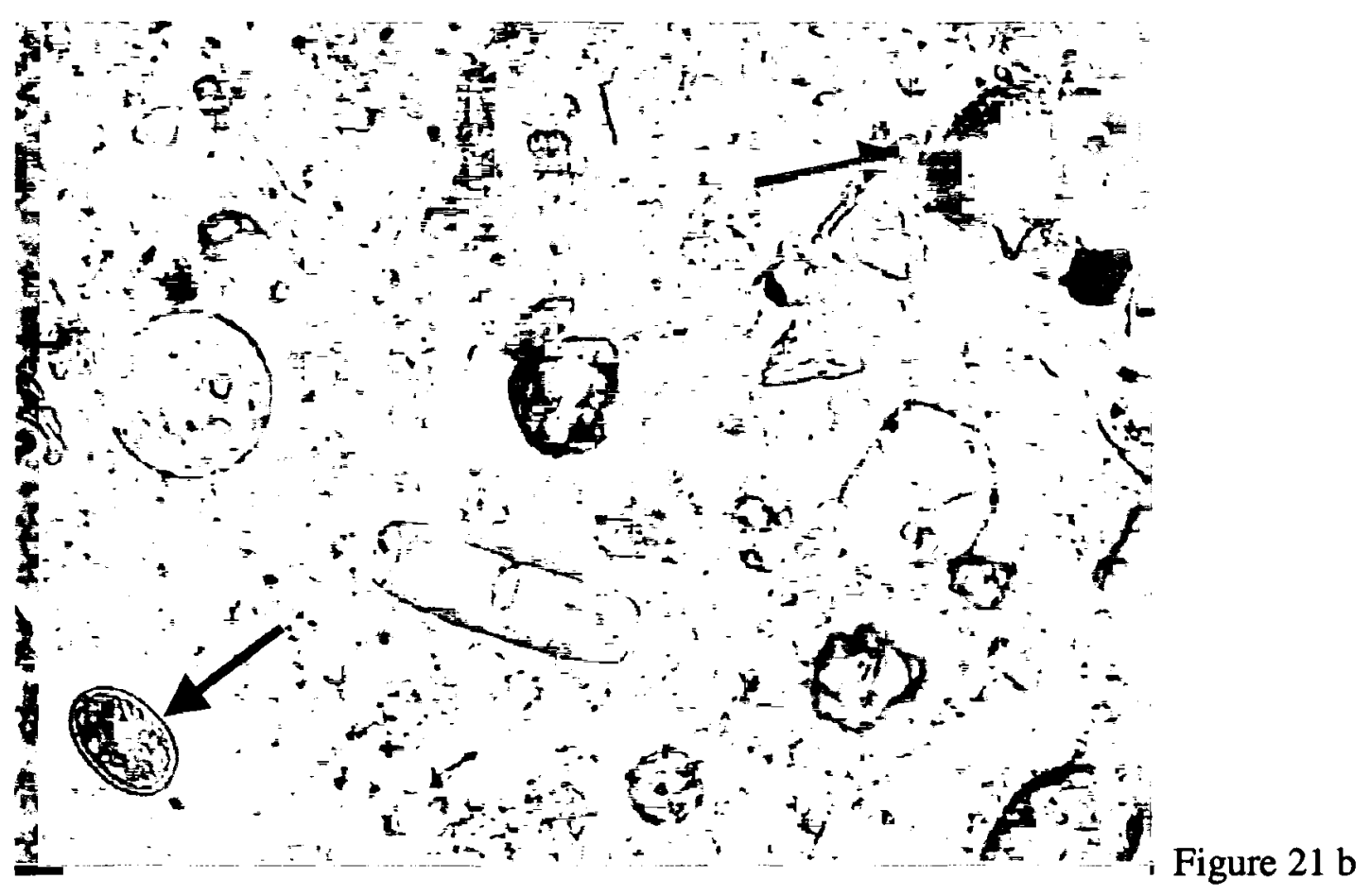

Figure 21. Photomicrographs $(200 \mathrm{x})$ of new cyst in upper right $(50 \mu \mathrm{m}$ long, red arrow) and smaller, similar-looking cyst with no eyespot in lower left (blue arrow) in a) epifluorescence and b) transmitted light. From June 2000, station 25, near-bottom sample (48 m). 


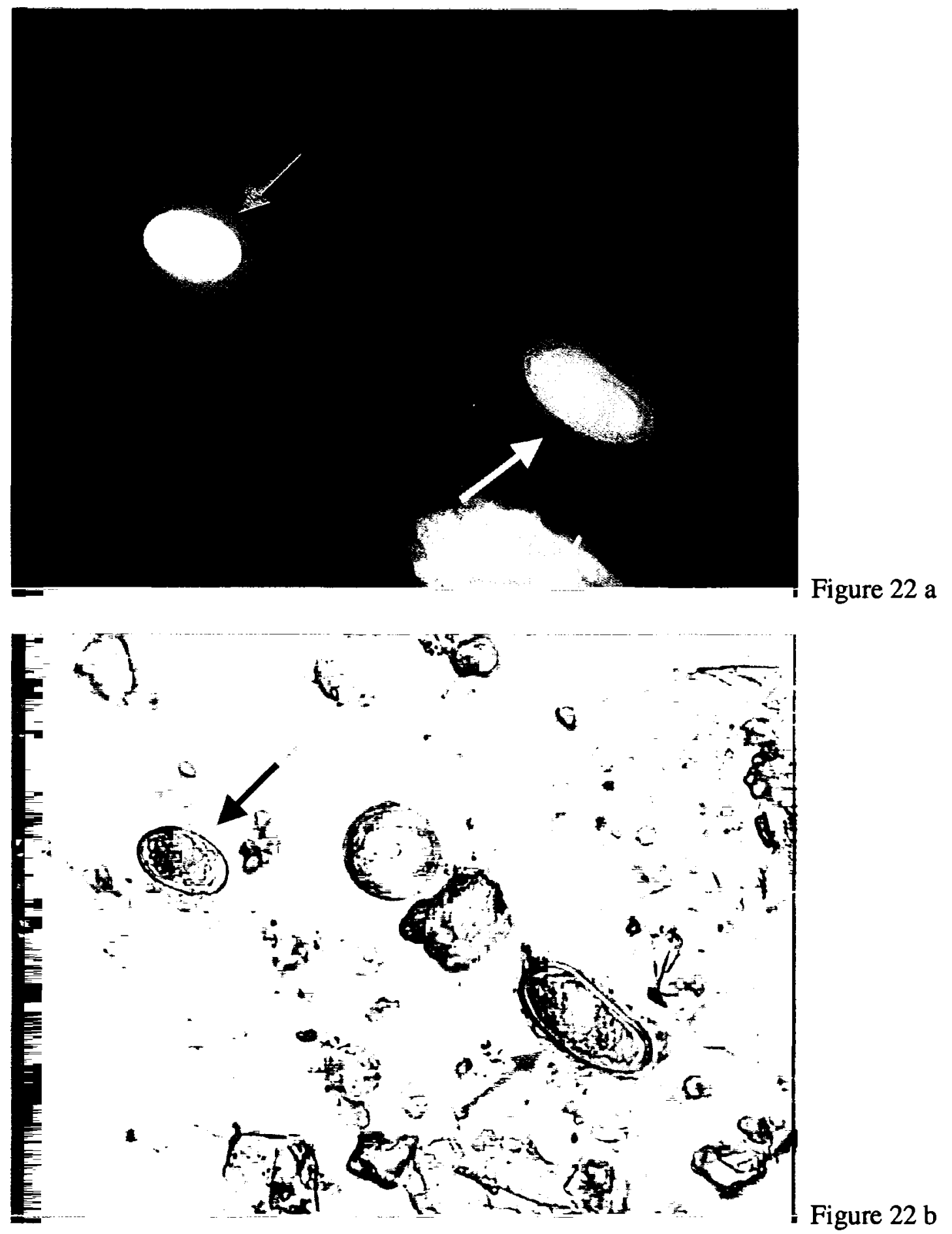

Figure 22. Photomicrographs (200x) of mature A. fundyense hypnozygote cyst at lower right (red arrow) and "opaque" or eyespot-less cyst at left (blue arrow) in a) epifluorescence and b) transmitted light. From June 2000, station 104, near-bottom sample (105 m). 


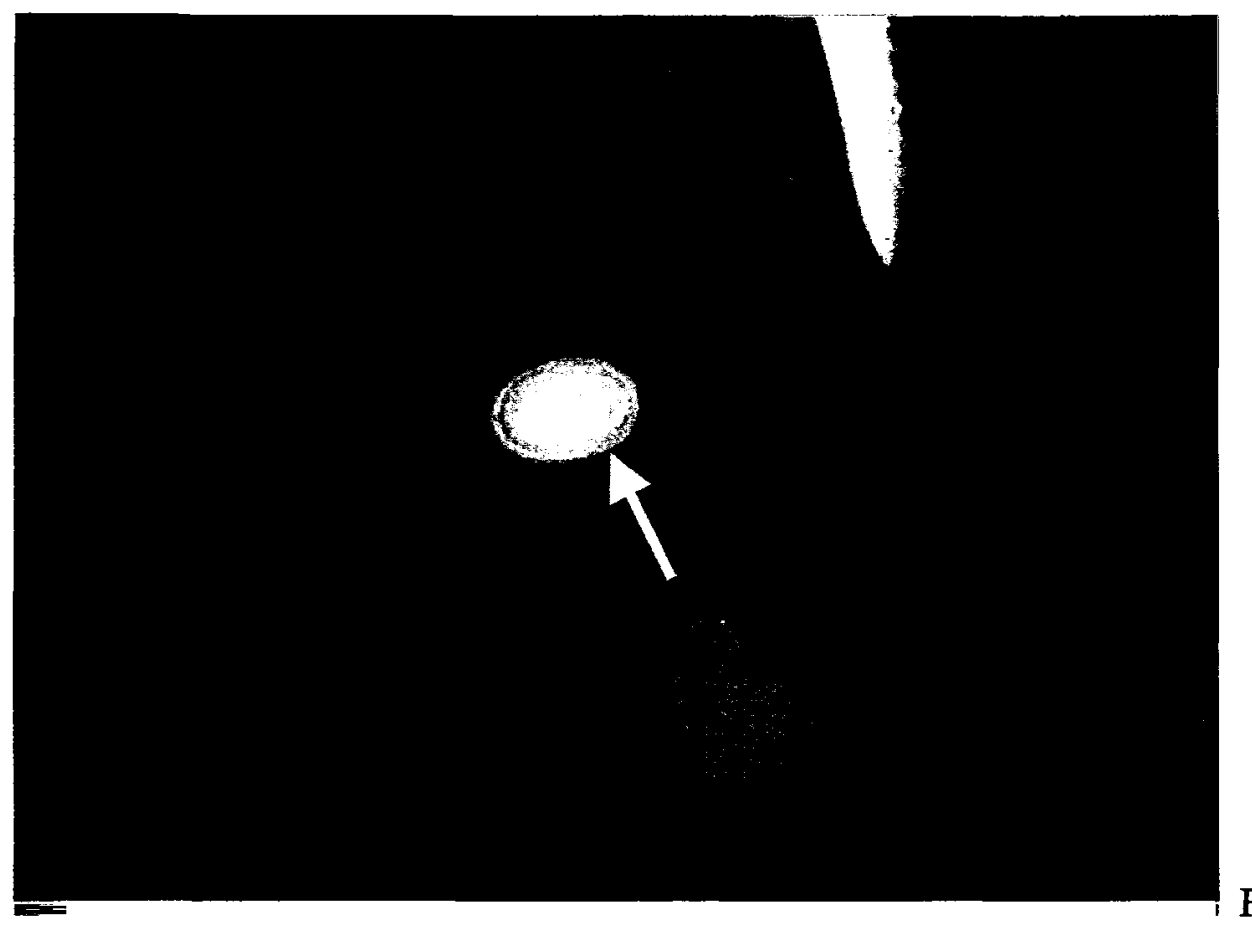

Figure 23 a

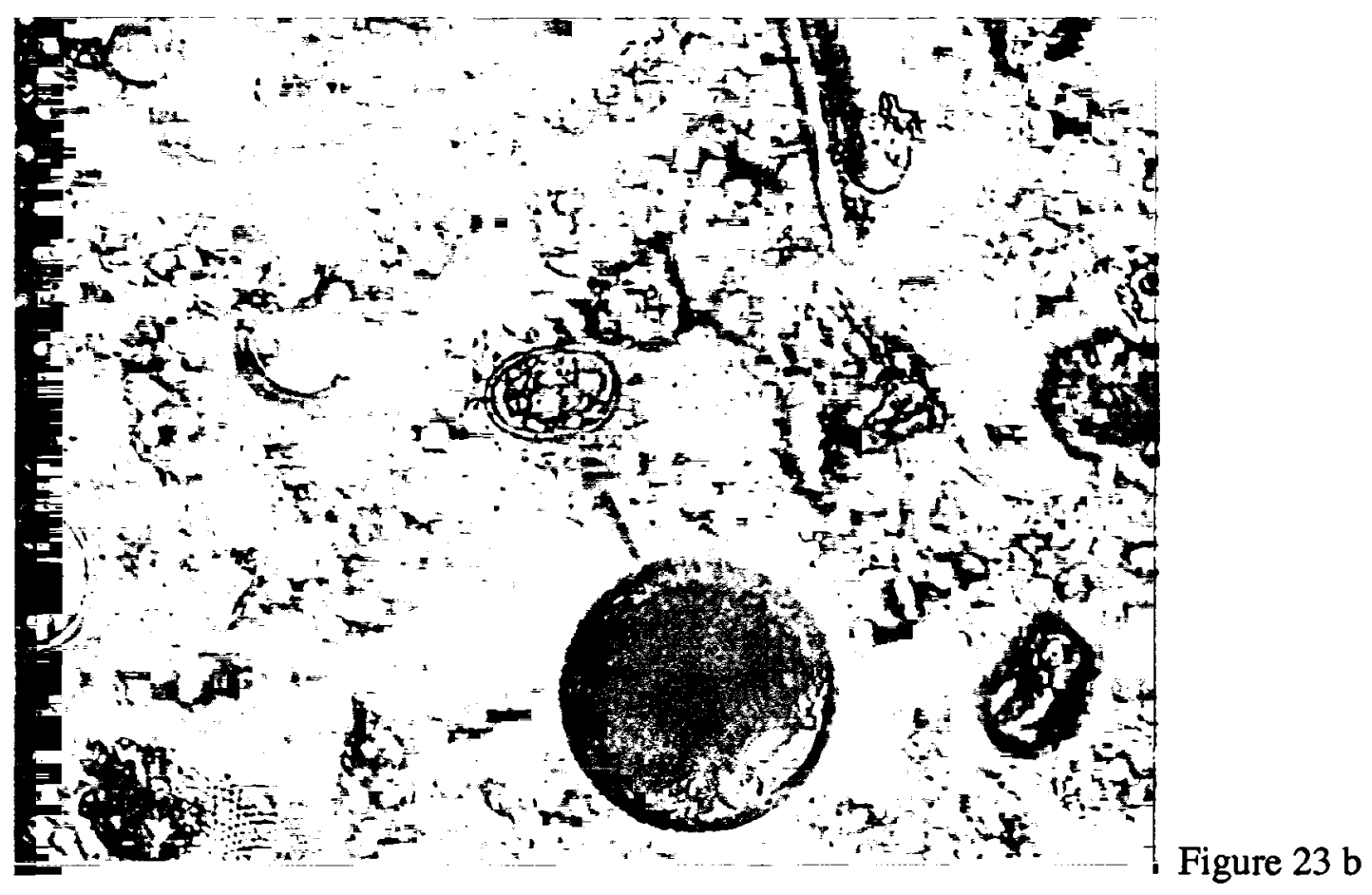

Figure 23. Photomicrographs $(200 \mathrm{x})$ of a small $(40 \times 25 \mu \mathrm{m})$ cyst or cell that strongly resembles an $A$. fundyense hypnozygote cyst in a) epifluorescence and b) transmitted light. From June 2000, station 116, near-bottom (97 m). 


\section{DISCUSSION}

\section{Vegetative Cells}

Very low concentrations of vegetative cells were found in February (see Figure 14). The endogenous clock causes germination to begin in February, so the cells we observed might have recently germinated or might have persisted through the winter months. The latter explanation is unlikely; light is very limited in January and turbulence is high, neither of which favors dinoflagellate growth. Although germination is possible in February, growth conditions are poor for $A$. fundyense vegetative cells and losses are likely high. Monthly observations in the Bay of Fundy rarely find A. fundyense vegetative cells before June (J. Martin, personal communication). Germination introduces a regular inoculum of vegetative cells to the water column starting in February, but the population does not become established until growth exceeds losses. If widespread populations of vegetative cells had been found, even at low concentrations, it would have indicated that hypnozygote cysts might not be necessary to spring vegetative

cell population establishment. The population found was sparse and patchy, likely a result of newly germinated cysts rather than an over-wintering population of vegetative cells. It remains more likely that cyst germination does reestablish the springtime vegetative cell population.

\section{Temporal Distribution of $A$. fundyense Hypnozygote Cysts}

Tables 4 and 5 show a summary of the data from the three cruises. As the cruise tracks and stations sampled were different on each cruise it is ill advised to base 
conclusions on the data in tabular form (especially given the large standard deviations calculated), however, general trends can be identified for further investigation.

Notably, samples with no cysts were counted in all months at all depths. This may be partly a result of insufficient sample size rather than a true absence of cysts in certain areas, but it also indicates that cyst presence is patchy, as are most components in the plankton (MacAlice 1970). The cause of this patchiness is likely physical rather than biological, at least in February and April. Cysts stop forming sometime in the fall. It is unknown whether cyst formation happens in isolated areas or throughout the gulf, but the dependence of sexual reproduction on the concentration of gametes implies that sexual fusion happens only in isolated patches. As soon as hypnozygote cysts develop from planozygotes they become immotile particles, falling slowly or held in suspension by vertical turbulence and transported by currents. By February planktonic cysts are far from where they were formed. The planktonic distribution of cysts is purely a function of the physical environment until new cysts form (beginning in June, according to microscope observations).

Intact A. fundyense hypnozygote cysts were one or two orders of magnitude more abundant in February than in April. In April empty cysts were nearly four times as abundant as intact cysts in near bottom samples, while in February intact cysts were nearly twice as abundant as empty cyst walls at that depth (see table 5). At other depths, empty cysts were typically twice as numerous as intact cysts. The biological explanation may be that the concentration of intact cysts decreases because of germination between February and April, but this is not the only possibility. The concurrent drop in concentration of intact and empty cysts indicates that physical factors are likely involved. Because near bottom vertical turbulence would have decreased or remained the same 


\begin{tabular}{|l|c|c|c|c|c|c|}
\hline & \multicolumn{2}{|c|}{ February 20-25 } & \multicolumn{2}{c|}{ April 24- May 2 } & \multicolumn{2}{c|}{ June 5-15 } \\
\hline & $\begin{array}{l}\text { Total \# } \\
\text { counted }\end{array}$ & $\begin{array}{l}\text { \# Samples } \\
\text { with no intact } \\
\text { cysts }\end{array}$ & $\begin{array}{l}\text { Total \# } \\
\text { counted }\end{array}$ & $\begin{array}{l}\text { \# Samples } \\
\text { with no intact } \\
\text { cysts }\end{array}$ & $\begin{array}{l}\text { Total \# } \\
\text { counted }\end{array}$ & $\begin{array}{l}\text { \# Samples } \\
\text { with no intact } \\
\text { cysts }\end{array}$ \\
\hline Surface & 11 & 3 & 10 & 10 & 4 & 4 \\
\hline Top of BNL & 14 & 2 & 24 & 14 & na & na \\
\hline $\begin{array}{l}\text { Near } \\
\text { Bottom }\end{array}$ & 11 & 1 & 33 & 22 & 28 & 6 \\
\hline
\end{tabular}

Table 4 a.

\begin{tabular}{|c|c|c|c|c|c|c|c|}
\hline & \multicolumn{2}{|c|}{ February 20-25 } & \multicolumn{2}{|c|}{ April 24-May 2} & \multicolumn{3}{|c|}{ June 5-15 } \\
\hline & intact & empty & intact & empty & intact & empty & now \\
\hline Surface & $\begin{array}{c}110 \\
(0-423) \\
\text { sdev }=153\end{array}$ & $\begin{array}{c}238 \\
(0-794) \\
\operatorname{sdev}=265\end{array}$ & $\mathbf{0}$ & 0 & 0 & $\begin{array}{c}18 \\
(0-71) \\
\text { sdev }=36\end{array}$ & 0 \\
\hline $\begin{array}{l}\text { Top of } \\
\text { BNL }\end{array}$ & $\begin{array}{c}318 \\
(0-1103) \\
\text { sdev }=376\end{array}$ & $\begin{array}{c}439 \\
(0-1586) \\
\text { sdev }=516\end{array}$ & $\begin{array}{c}31 \\
(0-327) \\
\text { sdev }=69\end{array}$ & $\begin{array}{c}78 \\
(0-618) \\
\text { sdev }=148\end{array}$ & - & - & $=$ \\
\hline $\begin{array}{l}\text { Near } \\
\text { Bottom }\end{array}$ & $\begin{array}{c}1685 \\
(0-8755) \\
\text { sdev }=2714\end{array}$ & $\begin{array}{c}886 \\
(0-2596) \\
\text { sdev }=820\end{array}$ & $\begin{array}{c}48 \\
(0-429) \\
\text { sdev }=99\end{array}$ & $\begin{array}{c}189 \\
(0-1607) \\
\text { sdev }=367\end{array}$ & $\begin{array}{c}131 \\
(0-464) \\
\text { sdev }=147\end{array}$ & $\begin{array}{c}225 \\
(0-1536) \\
\text { sdev }=331\end{array}$ & $\begin{array}{c}11 \\
(0-69) \\
\text { sdev }=21\end{array}$ \\
\hline
\end{tabular}

Table $4 \mathrm{~b}$.

Table 4. a) Number of samples counted for each cruise at each depth and the number of samples that contained no intact cysts. b).Average intact and empty cyst concentrations, ranges (in parentheses), and standard deviation reported in cysts $\mathrm{m}^{-3}$. See Table 4 a for number of samples counted in each category. 
from February to April, the drop in relative concentration of intact versus empty cysts could be explained physically rather than biologically. If less energy is available to keep cysts in suspension, the denser intact cysts might preferentially settle while the lighter empty cysts remain in suspension. As both cruises occurred between a full and new moon, or during neap tides as opposed to spring tides, both cruises should have seen roughly the same strength of tidal mixing. Wind speeds were different from month to month, with greater winds during the April cruise, which experienced a gale during the first four days. That said, the relative decrease in intact cysts relative to empty cysts is likely a combination of both germination and the decreasingly energetic environment. Additionally, empty cysts may persist for years without degradation; empty cysts observed may have accumulated over many years, not only from the most recent germination.

Although the difference is not significant, the mean concentration of intact cysts in near bottom samples shows an increase from April to June, at least in part because of the formation of new cysts (see table 5 and Figure 17). The range, however, is nearly identical between April and June. Some of the difference between April and June may be attributable to the variation in sample location and number between the April and June cruises.

The increase in empty cysts in the near bottom from April to June can be explained by the settling of the empty cysts left over from springtime germination. As empty cysts have low densities, it is feasible that they might take a long time to reach the bottom. According to evidence from endogenous clock studies, germination continues into July, so there is likely a steady supply of newly emptied cyst walls throughout the summer. It is unknown how long empty cyst walls persist in the environment, so it is 
impossible to say where the cyst walls originated or when they were abandoned. An alternative explanation for the increase in empty cysts is resuspension of very old cyst walls.

\section{Spatial Distribution of $A$. fundyense Hypnozygote Cysts}

With the exception of February station 11, the highest concentrations of cysts were found near the bottom in the Bay of Fundy by all three cruises. This pattern is uncertain in February due to the cruise track, but it is supported by subsequent cruise results. As well as having the highest cyst concentration, the Bay of Fundy also had the most consistent abundances of planktonic cysts. The only area that consistently had cysts at multiple depths was that to the northeast of Grand Manan Island in the mouth of the Bay of Fundy over the dense benthic cyst deposit mapped by White and Lewis (1982). There were also far fewer stations with no cysts inside the Bay of Fundy than outside of the Bay of Fundy. Other areas that consistently had cysts were in the western Gulf of Maine, directly south of Penobscot Bay (see Figures 13 and 14), although this is poorly

resolved as only the April and June cruises sampled here. Notably, this area has some of the highest sedimentary cyst concentrations of the gulf (see Figure 11)

When they are in suspension, cysts can be advected by currents throughout the gulf. One example of this is the cyst found in the surface sample from February Station 11. This cyst could not have been brought to the surface by local resuspension events because the water here is strongly stratified in February (see Figure 24). Both temperature and salinity have strong gradients between 75 and $100 \mathrm{~m}$ depth, indicating that mixing does not extend from the surface to the bottom. Above $75 \mathrm{~m}$ there is no variation in salinity or temperature, which indicates that the surface waters are well 

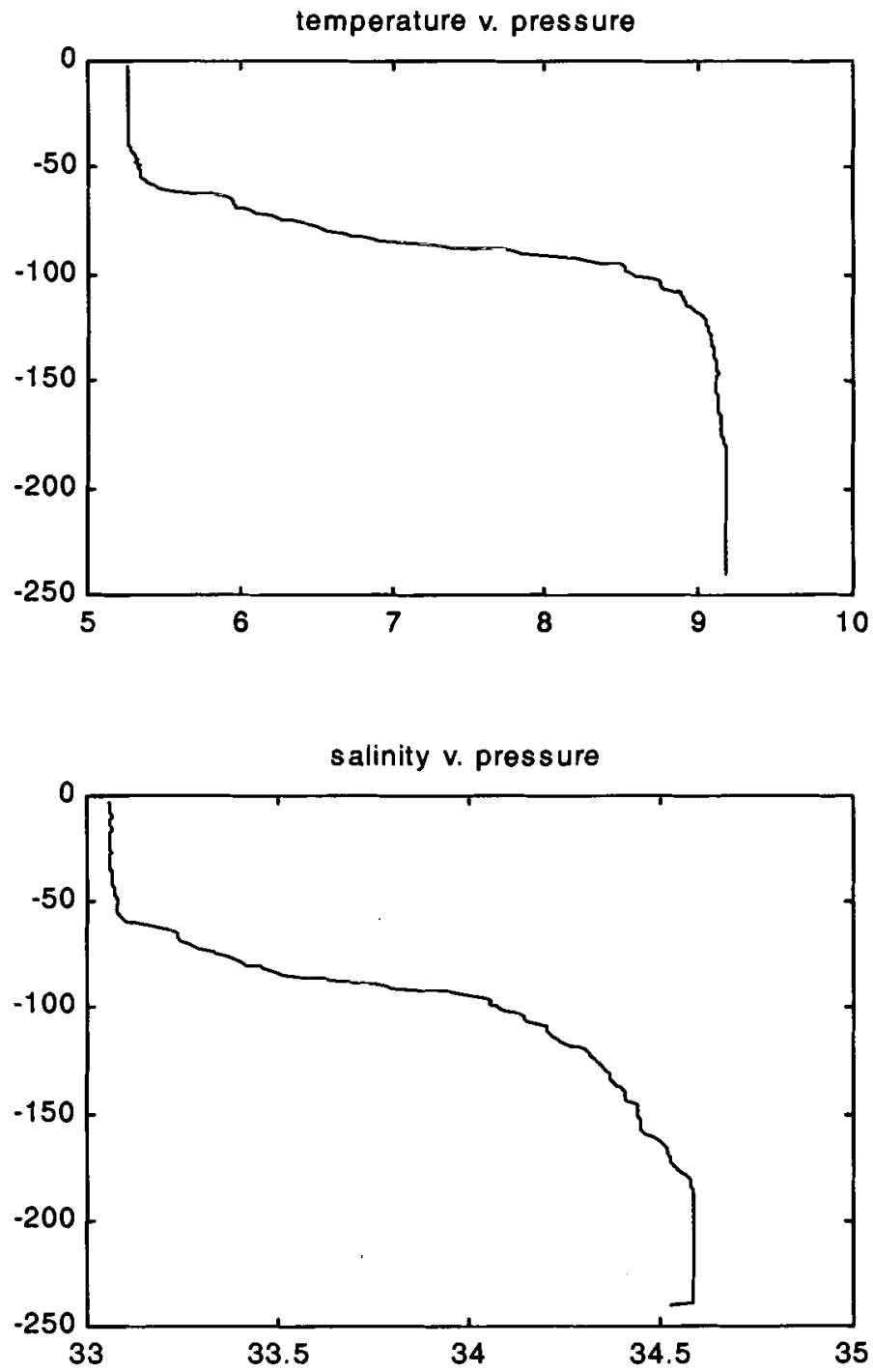

Figure 24. Station 11, February 2000, hydrographic data from CTD cast. 
mixed. The cyst found in the surface sample at this station was likely held in suspension by turbulence in this layer as it traveled away from the area in which the cyst was resuspended, or it was held in the surface layer since its formation. Sea surface temperature varies so little in February that it is hard to trace surface currents in satellite images, however, if surface circulation patterns in February are consistent with those in spring and summer, then part or all of the EMCC turns offshore in the vicinity of Penobscot Bay and likely carries cysts over Jordan Basin in the cyclonic circulation in the eastern gulf. Although it is dangerous to make conclusions on the evidence of only one cyst, its occurrence does suggest that cysts can be held in suspension for extended periods of time.

The highest density of cysts was found in the near bottom sample at Station 11 in February. Empty cysts were not highly concentrated in the near bottom sample at this location. Samples from intermediate depths at this location had slightly more empty cysts than intact ones. In the bottom sample intact cysts outnumbered empty cysts by a factor of ten. Elsewhere, the relative patterns in distributions of empty cysts to intact cysts are fairly consistent (visual comparisons of Figures $12 \mathrm{~b}$ and $13 \mathrm{~b}, 15 \mathrm{~b}$ and $16 \mathrm{~b}$ indicate that stations with elevated intact cyst concentrations had elevated empty cyst concentrations). A portion of the cysts in this sample may have formed in the 1999 summer and been entrained in the gyre circulation around Jordan Basin and therefore prevented from settling.

Another interesting pattern revealed by this study is that planktonic cysts are not confined to coastal areas, but occur throughout the sampling area. Nor are they confined to the eastern Gulf of Maine, although there does appear to be a gradient of abundance from east to west, with highest densities mostly in the Bay of Fundy. Cysts were widely 
distributed, although not ubiquitous, in bottom and top of bottom nepheloid layer samples throughout the Gulf of Maine, especially over known concentrations of benthic cysts in the Bay of Fundy and offshore from Penobscot Bay (White and Lewis 1982; Figure 11). The concentrations of cysts found in the offshore transect in February were higher than any found in subsequent months, with the exception of the stations offshore from Penobscot Bay (Figure 12). These samples (stations 1-3 on Figures 12 a and 13 a) were collected for researchers at Woods Hole Oceanographic institution; no cysts were found in these samples (Keafer, personal communication). In April and June, cysts were found at stations in this vicinity (Figures 15, 17). The cysts found in April and most of the cysts found in June were not newly formed cysts; they must have remained in the water column for the eight interceding months, or, more likely, they were resuspended, perhaps from the high concentration of benthic cysts south of Penobscot Bay (Figure 11).

Table 5 shows the results of pooling samples and calculating medians, $20^{\text {th }}$, and $80^{\text {th }}$ percentiles. The pools consisted of: all samples, those within the Bay of Fundy northeast of a line drawn from Yarmouth, Nova Scotia, to Cutler, Maine, and those in the Gulf of Maine excluding the Bay of Fundy samples (labeled GoM-BoF, including all the samples southwest of the Yarmouth-Cutler line). Median cyst concentrations show the expected trend if the cysts and empty cysts came from a benthic source, that is, densities are greatest near bottom and decrease with distance from the bottom. Complicated currents and mixing, especially sporadic mixing events, may help to explain the widespread deviation from this expected pattern. For example, a strong storm might cause resuspension of sediment and cysts well into the upper water column, with sediment and cysts load increasing from surface to bottom. After the mixing event subsides, vertical gradients in horizontal advection might leave that water column with a 
Table 5. Pooled data analysis. Average depths are reported in meters; medians, percentiles, and ranges are all reported in cysts $\mathrm{m}^{-3} .0 .2$ and 0.8 columns report first and fifth quartiles, or $20^{\text {th }}$ and $80^{\text {th }}$ percentiles; one fifth of the samples have cyst concentrations below the $20^{\text {th }}$ percentile, and one fifth of the samples have cyst concentrations above the $80^{\text {th }}$ percentile. The All Stations pool includes all samples, the Bay of Fundy pool includes samples from stations within the Bay of Fundy region northeast of a line drawn from Yarmouth, Nova Scotia, to Cutler, Maine, and the Gulf of Maine (labeled GoM-BoF) pool is all samples from stations west of the Yarmouth-Cutler line. 


\begin{tabular}{|c|c|c|c|c|c|c|c|}
\hline \multicolumn{8}{|c|}{ February, 2000 R/V Delaware II } \\
\hline \multicolumn{8}{|c|}{ F- } \\
\hline$n$ & $\begin{array}{l}\text { Average depth } \\
\text { (m) }\end{array}$ & Level & $\begin{array}{c}\text { Median } \\
\left(\text { cysts } \mathrm{m}^{-1}\right)\end{array}$ & 0.2 & 0.8 & \multicolumn{2}{|c|}{ Range } \\
\hline 11 & 2 & Surface & 0 & 0 & 249 & 0 & 423 \\
\hline 14 & 117 & Top of BNL & 155 & 5 & 697 & 0 & 1103 \\
\hline 11 & 134 & Near Bottom & 391 & 91 & 2723 & 0 & 8755 \\
\hline \multicolumn{8}{|c|}{ Bay of Fundy } \\
\hline$n$ & Average depth & Level & Median & 0.2 & 0.8 & \multicolumn{2}{|c|}{ Range } \\
\hline 5 & 2 & Surface & 249 & 149 & 320 & 0 & 423 \\
\hline 5 & 96 & Top of BNL & 793 & 483 & 966 & 207 & 1103 \\
\hline 5 & 113 & Near Bottom & 708 & 487 & 2795 & 391 & 3083 \\
\hline \multicolumn{8}{|c|}{$G o M-B o F$} \\
\hline$n$ & Average depth & Level & Median & 0.2 & 0.8 & \multicolumn{2}{|c|}{ Range } \\
\hline 6 & 2 & Surface & 0 & 0 & 0 & 0 & 56 \\
\hline 9 & 129 & Top of BNL & 69 & 0 & 152 & 0 & 351 \\
\hline 6 & 152 & Near Bottom & 176 & 0 & 326 & 0 & 8755 \\
\hline \multicolumn{8}{|c|}{ April-May, 2000 R/V Cape Hatteras } \\
\hline \multicolumn{8}{|c|}{ All stations } \\
\hline$n$ & Average depth & Level & Median & 0.2 & 0.8 & \multicolumn{2}{|c|}{ Range } \\
\hline 9 & 2 & Surface & 0 & 0 & 0 & 0 & 0 \\
\hline 24 & 116 & Top of BNL & 0 & 0 & 36 & 0 & 327 \\
\hline 33 & 121 & Near Bottom & 0 & 0 & 74 & 0 & 429 \\
\hline \multicolumn{8}{|c|}{ Bay of Fundy } \\
\hline$n$ & Average depth & Level & Median & 0.2 & 0.8 & \multicolumn{2}{|c|}{ Range } \\
\hline 3 & 2 & Surface & 0 & 0 & 0 & 0 & 0 \\
\hline 5 & 112 & Top of BNL & 34 & 0 & 94 & 0 & 327 \\
\hline 10 & 108 & Near Bottom & 52 & 0 & 134 & 0 & 429 \\
\hline \multicolumn{8}{|c|}{$G o M-B o F$} \\
\hline$n$ & Average depth & Level & Median & 0.2 & 0.8 & \multicolumn{2}{|c|}{ Range } \\
\hline 6 & 2 & Surface & 0 & 0 & 0 & 0 & 0 \\
\hline 19 & 117 & Top of BNL & 0 & 0 & 36 & 0 & 107 \\
\hline 23 & 126 & Near Bottom & 0 & 0 & 0 & 0 & 300 \\
\hline \multicolumn{8}{|c|}{ June, 2000 R/V Cape Hatteras } \\
\hline \multicolumn{8}{|c|}{ All stations } \\
\hline$n$ & Average depth & Level & Median & 0.2 & 0.8 & \multicolumn{2}{|c|}{ Range } \\
\hline 4 & 2 & Surface & 0 & 0 & 0 & 0 & \\
\hline 28 & 132 & Near Bottom & 71 & 75 & 197 & 0 & 464 \\
\hline \multicolumn{8}{|c|}{ Bay of Fundy } \\
\hline$n$ & Average depth & Level & Median & 0.2 & 0.8 & \multicolumn{2}{|c|}{ Range } \\
\hline 2 & 2 & Surface & 0 & 0 & 0 & 0 & 0 \\
\hline 10 & 113 & Near Bottom & 143 & 38 & 125 & 0 & 464 \\
\hline \multicolumn{8}{|c|}{ GoM-BoF } \\
\hline$n$ & Average depth & Level & Median & 0.2 & 0.8 & \multicolumn{2}{|c|}{ Range } \\
\hline 2 & 2 & Surface & 0 & 0 & 0 & 0 & 0 \\
\hline 18 & 143 & Near Bottom & 71 & 0 & 163 & 0 & 464 \\
\hline
\end{tabular}


very different pattern from the even gravity-driven gradient initially present. Figures 25 (a)-(c) are scatter plots of all data points in each pool, plotted by average depth. When looking at Figure 25(a), it is important to recall that fully half of the stations visited in February were within the Bay of Fundy where planktonic cyst concentrations are consistently high. The spread of data points is large for all three categories in all months. In February, the Bay of Fundy cyst concentrations were in general larger than those outside of the Bay of Fundy. In April, the high concentration points also were found in the Bay of Fundy, but zero counts were found there as well, so no clear trend exists. In June no patterns are apparent. The strongest pattern this Figure shows may be temporal: February samples had more cysts than later months.

There are a number of likely explanations for the greater concentration of planktonic cysts in the Bay of Fundy than elsewhere in the Gulf of Maine. The biological explanation rests on the production of cysts. Because they are sexually produced, cysts will only be formed where gamete concentration is sufficient for encounter and fusion. The minimum abundance of gametes may be reached in typical blooms, or it may only be reached in isolated thin layers or patches. In any case, high ambient vegetative cell Physical factors also favor high concentrations of planktonic cysts in the Bay of Fundy. The highest tides and the highest concentrations of benthic cysts in the Gulf of Maine are both found in the Bay of Fundy (White and Lewis 1982), making resuspension of sediment and benthic cysts likely. The Bay of Fundy also provides a mechanism by which and an environment in which populations might reach bloom density. Gyre circulation in the mouth of the Bay of Fundy may act to retain both cells and cysts within the Bay, as suggested by Martin and White (1988). These populations may get advected periodically out of the Bay of Fundy and entrained into the Eastern Maine Coastal 

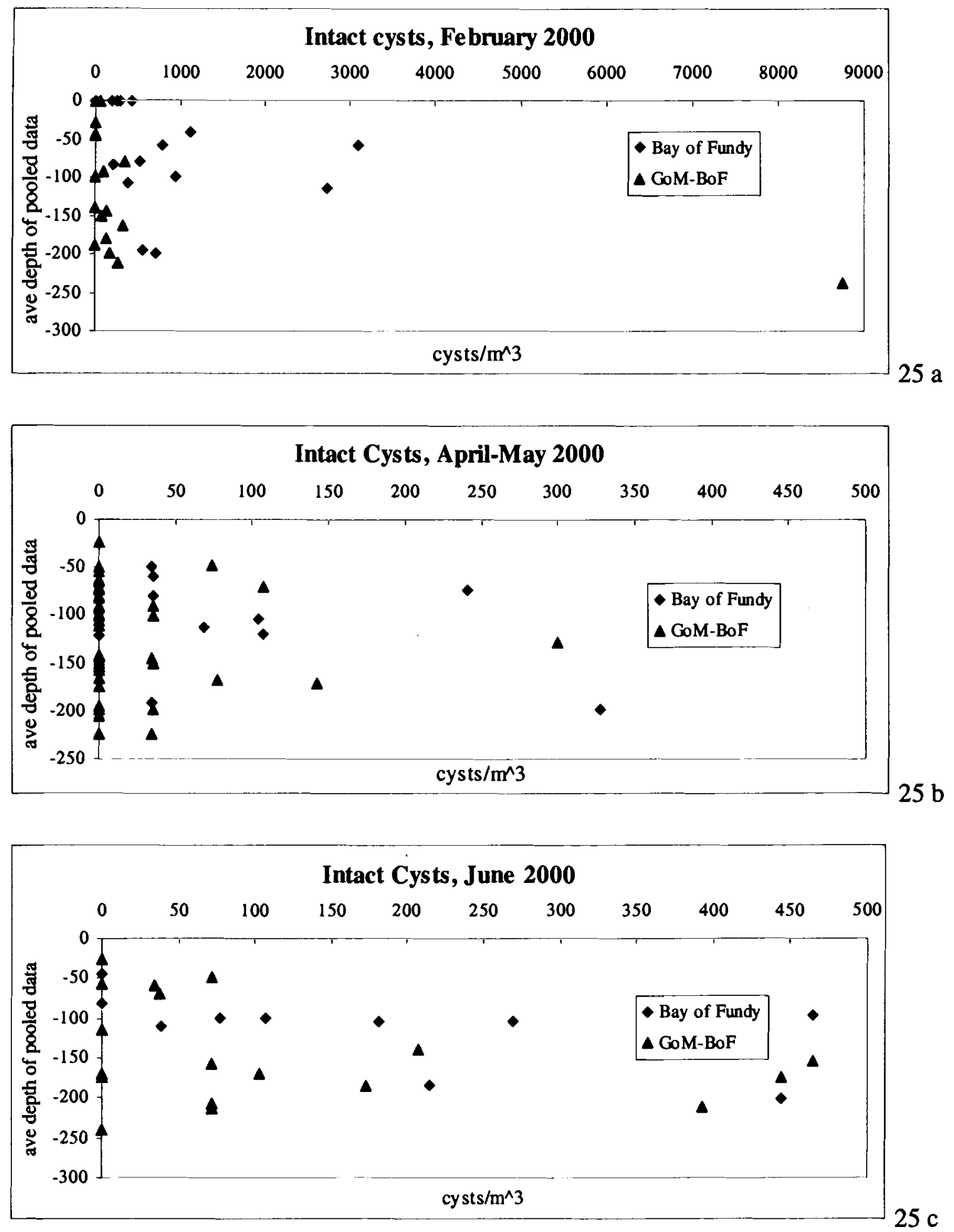

Figure 25. Cyst concentrations in the Bay of Fundy region and in the greater Gulf of Maine plotted against depth by cruise. In February cyst concentrations in the Bay of Fundy region are slightly higher than in the greater Gulf of Maine. 
Current (EMCC) where they also find favorable growth conditions. Eddies along the periphery of the EMCC may give these populations time to grow to the concentrations observed during ECOHAB cruise work (Townsend et al. 2001). Another possibility is that cysts in the waters west and south of Grand Manan Island, outside of the Bay of Fundy proper but inside the track of the EMCC (see Figure 10) initiate the vegetative cell population in the offshore eastern Gulf of Maine (Townsend et al. 2001). The high nutrient signature of the EMCC has been credited to tidal currents that mix slope water up from Jordan Basin into surface waters in the vicinity of Grand Manan Island (Townsend et al. 1987).

There are many possible physical and biological explanations for the decline in abundance of suspended cysts from February to June. As stated before, germination begins in February and continues through the summer, so some loss of intact cysts is expected as cysts begin to germinate. The energetic physical environment of the Bay of Fundy also offers an explanation for the higher concentration of cysts in February. Stratification is nearly nonexistent in winter in the Bay of Fundy and Gulf of Maine (except in deep areas such as Jordan Basin, and near the Northeast Channel). Consequently, the mixing energy from winter storms and swell events can penetrate deeper into the water column, potentially resuspending sediment and cysts and keeping them in suspension. As spring progresses stratification develops, reducing the depth to which surface mixing extends. With lower energy in the deep water column, cysts that were held in suspension during the energetic winter months may settle to the bottom.

The elevated concentrations of cysts in February in the Bay of Fundy likely reflect both the energetic environment of the Bay of Fundy as well as the persistence of the $A$. fundyense population there. Whether there were high concentrations outside of the 
Bay of Fundy in any of the sample months, February especially, is impossible to determine given the limited number of stations sampled.

\section{Numerical Abundances of Water Column Cysts and Available Benthic Cysts}

In February cysts were suspended in the surface waters in the Bay of Fundy at concentrations on the order of $10^{2}$ cysts $\mathrm{m}^{-3}$ and in the near bottom waters concentrations were between $10^{2}-10^{3}$ cysts $\mathrm{m}^{-3}$. The highest published cyst concentrations in the Bay of Fundy sediments are $10^{3}$ cysts $\mathrm{cm}^{-3}$ in $80-160 \mathrm{~m}$ of water east northeast of Grand Manan Island (White and Lewis 1982). Before we can compare these concentrations some attempt must be made to address the fact that most of the benthic cysts are buried. An Alexandrium planomeiocyte $40 \mu \mathrm{m}$ long that emerges from a cyst buried $1 \mathrm{~cm}$ deep must swim 250 body-lengths through sediments. No research has been done on planomeiocytes' ability to escape sediment burial, but this seems problematic. A conservative approach to estimating the number of benthic cysts available to germinate is to assume a uniform distribution of cysts in the sediment with depth and to assume that only the uppermost $1 \mathrm{~mm}$ layer of cysts will be able to excyst, rather than the full $1 \mathrm{~cm}^{3}$. By this calculation, in the Bay of Fundy where benthic cyst concentrations are $10^{3} \mathrm{~cm}^{3}$, the number of cysts available to germinate would be $\left(\frac{10^{3} \mathrm{cysts}}{1 \mathrm{~cm} \times 1 \mathrm{~cm} \times 1 \mathrm{~cm}}\right) \times \frac{1 \mathrm{~cm}}{10 \mathrm{~mm}}=\frac{10^{2} \mathrm{cysts}}{1 \mathrm{~cm} \times 1 \mathrm{~cm} \times 1 \mathrm{~mm}}$. Converting this to square meters, we find that we have $10^{6}$ cysts $\mathrm{m}^{-2}$ in the top $1 \mathrm{~mm}$ of sediment available to germinate. Now we must calculate how many cysts are available in the water column to germinate. Using a conservative concentration of $10^{2}$ cysts $\mathrm{m}^{-3}$ throughout the $80-160 \mathrm{~m}$ water column, total suspended cysts available to germinate are $\left(10^{2}\right.$ cysts $\left.\mathrm{m}^{-3}\right) \times(80-160 \mathrm{~m})=10^{3}-10^{4}$ cysts 
$\mathrm{m}^{-2}$, which is two or three orders of magnitude less than benthic cyst densities.

Observations in salt ponds found that only a small percentage of cysts in bottom sediments actually germinate, so the difference between suspended cyst and benthic cyst concentrations may be only one or two orders of magnitude (Anderson et al. 1983).

Benthic cyst concentrations shown in Figure 11 are an order of magnitude below those found by White and Lewis (1982), even at the five stations inside the Bay of Fundy (Anderson et al. unpublished). This may be due to discrepancies in sampling location or to annual variation in benthic cyst concentrations due to both the variability in annual $A$. fundyense populations and physical processes. This variability makes it difficult to accurately evaluate benthic and suspended cyst numbers without concurrent benthic and water column sampling. However, comparing suspended cyst concentrations with Figure 11 benthic cyst concentrations will indicate a range of ratios that might be expected. For example, using the same calculation outlined above and evaluating the area southwest of Grand Manan, no difference is found between the number of cysts on the bottom and cysts available in the water column even before factors controlling germination rate are considered $\left[\left(\frac{5 \times 10^{2} \text { cysts }}{1 \mathrm{~cm} \times 1 \mathrm{~cm} \times 1 \mathrm{~cm}}\right) \times \frac{1 \mathrm{~cm}}{10 \mathrm{~mm}} \times \frac{100 \mathrm{~cm} \times 100 \mathrm{~cm}}{\mathrm{~m} \times \mathrm{m}}=\frac{5 \times 10^{4} \mathrm{cysts}}{1 \mathrm{~m} \times 1 \mathrm{~m} \times 1 \mathrm{~mm}}\right.$ on the bottom and $\frac{5 \times 10^{2} \text { cysts }}{m^{3}} \times 100 \mathrm{~m}=\frac{5 \times 10^{4} \text { cysts }}{m^{2}}$ in the water column].

Germination in light may occur 8 times faster than germination in darkness (Anderson et al. 1987). Temperatures in the Gulf of Maine at the onset of germination are around $5^{\circ} \mathrm{C}$, which is near the minimum required. Given the nearly equal abundances of suspended cysts and surficial benthic cysts and the more favorable conditions in the water column, suspended cysts could contribute substantially to the 
spring inoculum of the A. fundyense vegetative cell population in the Bay of Fundy and in the EMCC and thus they warrant further consideration.

\section{Spatial and Temporal Resuspension Potential}

In assessing the relative potential for pelagic or benthic cysts to establish the spring vegetative cell population it is important to determine whether or not it is physically possible for benthic cyst beds to initiate spring blooms. One approach to this problem is to evaluate the energy available in the water column for vertical mixing and transport. The highest concentrations of benthic cyst are deep $(>100 \mathrm{~m})$. Elsewhere, benthic cyst populations are present but less dense (see Figure 11). For any of these benthic cysts to contribute to the springtime initiation of the vegetative cell population, cysts or germlings must escape the bottom boundary layer and reach the euphotic zone. Escape from the boundary layer can happen biologically (planomeiocytes and vegetative cells can swim $10 \mathrm{~m} /$ day) or physically (resuspension by benthic shear stresses from tidal currents and surface waves or physical disturbance of sediment by benthic or pelagic animals, trawling, etc.). Once cells or cysts have escaped the boundary layer, they must get to the euphotic zone (quickly in the case of cells that have limited energy reserves, eventually in the case of cysts). Again, vertical turbulence plays a large role (vegetative cells can only swim $10 \mathrm{~m} /$ day). The largest impediment to this vertical turbulence is stratification of the water column. Water column stratification is generally weakest in wintertime, when surface cooling and increasingly frequent storms extract buoyancy from surface waters. Stratification develops as surface waters warm and freshen with increased springtime riverine input. If tidal currents are sufficiently strong and water depth shallow, coastal waters may remain unstratified throughout the summer (Simpson 
and Hunter 1974). In the Gulf of Maine areas with near year round top to bottom mixing include the area south and west of Grand Manan Island at the entrance to the Bay of Fundy, some regions on Georges Bank, the Scotian Shelf, and a near continuous band adjacent to the coast of eastern Maine and New Brunswick (Loder and Greenberg 1978).

Where waters are unstratified, one can expect that vertical turbulence, upwelling, etc., might bring cells or suspended cysts from the bottom to the surface; where water is stratified, newly hatched dinoflagellates would have to swim upwards through the pycnocline (Joint et al. 1997). If vegetative cells depend on vertical mixing to bring them to the surface, those cells that germinated from the bottom may have difficulty in reaching the surface in waters that are stratified. Under this assumption, benthic cysts may only be able to contribute to the establishment of surface vegetative cell populations before seasonal stratification develops or in areas that remain well mixed. Planktonic hypnozygote cysts above the pycnocline may contribute to surface vegetative cell populations regardless of the strength of stratification. The higher in the water column cells germinate the shorter their transit to the surface will be and the more likely they are to reach the euphotic zone.

Evaluating the critical benthic shear stress required to resuspend cysts is the first step toward determining where and when cysts, or planomeiocytes that emerged from benthic cysts, might be resuspended in the Gulf of Maine. The second step is to identify the areas in the gulf that are prone to greater shear stress (e.g., shallower areas exposed to large waves and swift currents). The Bay of Fundy, with its shallow cyst beds and great tidal energy, is one area that likely experiences high benthic shear stresses. The fact that this study found A. fundyense hypnozygote cysts in the water column in February on both 
sides of Grand Manan Island and elsewhere is evidence that cysts are resuspended from the bottom.

To determine the shear stress $(\tau)$ necessary to resuspend a hypnozygote cyst, we used a version of the Shields diagram showing the empirically derived relationship between the Yalin parameter and shear stress (p. 187, Middleton and Southard 1984). The Yalin parameter equals $\left[\frac{\left(\rho_{s}-\rho\right) g D^{3}}{\rho v^{2}}\right]^{\frac{1}{2}}$, where $\rho_{s}$ is the density of the particle $(1.3 \mathrm{~g}$ $\left.\mathrm{cm}^{3}\right)$ and $\rho$ is the density of the water $\left(1.03 \mathrm{~g} \mathrm{~cm}^{3}\right), g$ is the gravitational constant, $D$ is the spherical equivalent diameter of a cyst $\left(3.4 \times 10^{-4} \mathrm{~cm}\right)$, and $v$ is the kinematic viscosity $\left(1.46 \times 10^{-2} \mathrm{~cm}^{2} \mathrm{~s}^{-1}\right)$. Using these values and solving for the Yalin parameter results in $\left[\frac{\left(1.3 \frac{\mathrm{g}}{\mathrm{cm}^{3}}-1.03 \frac{\mathrm{g}}{\mathrm{cm}^{3}}\right) \times 981 \frac{\mathrm{cm}}{\mathrm{s}^{2}} \times\left(3.4 \times 10^{-3} \mathrm{~cm}\right)^{3}}{1.03 \frac{\mathrm{g}}{\mathrm{cm}^{3}} \times\left(1.46 \times 10^{-2} \frac{\mathrm{cm}^{2}}{\mathrm{~s}}\right)^{2}}\right]^{\frac{1}{2}}=0.2$. The intersect of this Yalin parameter value with a plot of empirical critical shear stress values is used to find the corresponding value for $\theta_{\mathrm{t}}$, which in turn equals $\frac{\tau_{c}}{\left(\rho_{s}-\rho\right) g D}$. Solving this relationship for $\tau_{c}$ give us a value of $0.18 \frac{g}{c m s^{2}}$, the critical shear stress. There is some uncertainty regarding this value, therefore we conservatively assume that values above $0.5 \frac{g}{\mathrm{cms}^{2}}$ would be sufficient to cause resuspension.

Benthic shear stress is a nonlinear function of current velocity (tidal or otherwise) and surface waves (Grant and Madsen 1979). As a first step in evaluating the benthic shear environment in the Bay of Fundy, the area where resuspension is most likely, we 
next evaluate current velocity alone for the benthic shear stress it may cause. If tidal currents are found to cause sufficient resuspension alone, we will know that the environment favors resuspension and will continue with the more complex evaluation of resuspension potential using both wave and tide data.

During spring tides, current velocities in the entrance to the Bay of Fundy regularly reach 3 knots (data from Nobeltec software package). The tidal current shear stress $\left(\tau_{c}\right)$ can be calculated using the equation $\tau_{c}=\frac{1}{2} f_{c} \rho U^{2}$. Using 3 knots $(5.556 \mathrm{~km}$ $\mathrm{hr}^{-1}$ or $154 \mathrm{~cm} \mathrm{~s}^{-1}$ ) for $U$, a value of 0.003 for $1 / 2 f_{c}$ as recommended by Souza (2001), and $1.03 \mathrm{~g} / \mathrm{cm}^{3}$ for $\rho, \tau_{c}$ equals $73 \frac{\mathrm{g}}{\mathrm{cms}^{2}}$ (Souza et al. 2001). This shear stress from current alone is two orders of magnitude greater than the critical shear stress, meaning that all cysts and cyst-sized particles will be resuspended. In fact, if we solve $\tau_{c}=\frac{1}{2} f_{c} \rho U^{2}$ for $\mathrm{U}$, using $1 \frac{\mathrm{g}}{\mathrm{cms}^{2}}$ for $\tau_{\mathrm{c}}$, we find that a current as slow as $18 \mathrm{~cm} \mathrm{~s}^{-1}$ (or $0.35 \mathrm{knots}$ ) are sufficient to resuspend cysts. Some loss of tidal current velocity will be expected from friction with the bottom, so these results apply to near-bottom currents rather than surface currents, especially in deep waters. We will now we continue with a more rigorous approach, considering both waves and tides.

Waves and swell can be more important than tidal current for resuspending sediment because they cause near-bed oscillations rather than steady flow. Under oscillatory conditions, benthic boundary layers do not have time to develop to the same depth that they do under a steady current condition, thus shear and shear stress are several orders of magnitude larger than for steady currents of similar magnitude. The largest 
waves and swells commonly observed in winter in the eastern Gulf of Maine or Bay of Fundy region are typically $5 \mathrm{~m}$ with periods of $6 \mathrm{~s}$ and $12 \mathrm{~s}$, respectively (data from National Data Buoy Center, buoy 44005, available on the web at www.ndbc.noaa.gov). Wave energy is roughly a factor of ten lower during summer months. The wavelength of these 6 and $12 \mathrm{~s}$ waves was taken to be the deepwater asymptotic limit of the transcendental functional relationship $T=\sqrt{\frac{L}{5.12}}$, where $T$ is the wave period and $L$ is the wavelength ( $L=225 \mathrm{~m}$ for $12 \mathrm{~s}$ swell and $L=56 \mathrm{~m}$ for $6 \mathrm{~s}$ wave) (Figure 1.7, Ippen 1966). The corresponding wave numbers for waves of these wavelengths are $k_{6}=$ $2 \pi / 56 \mathrm{~m}=0.112 \mathrm{~m}^{-1}$ and $\mathrm{k}_{12}=2 \pi / 225 \mathrm{~m}=0.028 \mathrm{~m}^{-1}$. The orbital velocity of the wave at depth $\left(u_{b}\right)$, was determined by solving the relationship $u_{b}=\frac{a g k}{\sigma} \frac{\cosh k(h+z)}{\cosh k h}$, where $a$ is the wave amplitude ( $1 / 2$ the wave height), $g$ is the gravitational constant, $\sigma$ is the radial frequency of the wave $(2 \pi / T), h$ is the water depth, and $z$ is the depth of interest, measured positive downward (Ippen 1966). For a 6s, $5 \mathrm{~m}$ wave,

$$
u_{b}=\frac{2.5 m \times 10 \frac{m}{s^{2}} \times 0.112 m^{-1}}{\frac{2 \pi}{6 s}} \frac{\cosh k(h+z)}{\cosh k h}=2.68 \frac{m}{s} \times \frac{\cosh 0.112 m^{-1}(h+z)}{\cosh k h}, \text { where }
$$

$2.68 \mathrm{~m} \mathrm{~s}^{-1}$ is the orbital velocity at the surface. For a $12 \mathrm{~s}, 5 \mathrm{~m}$

wave, $u_{b}=\frac{2.5 m \times 10 \frac{m}{s^{2}} \times 0.028 m^{-1}}{\frac{2 \pi}{12 s}} \frac{\cosh k(h+z)}{\cosh k h}=1.33 \frac{m}{s} \times \frac{\cosh 0.028 m^{-1}(h+z)}{\cosh k h}$, where $1.33 \mathrm{~m} \mathrm{~s}^{-1}$ is the orbital velocity at the surface. For a first analysis, we will use $100 \mathrm{~m}$ as the depth; this depth marks the transition between abundant benthic cysts and less abundant cysts, and is a good reference depth for use around the Gulf of Maine. At a 
depth of $100 \mathrm{~m}$ the orbital velocity, $u_{b}$, of a $6 \mathrm{~s}$ wave is equal to zero, that is, the water motion caused by a $6 \mathrm{~s}$ wave does not penetrate to $100 \mathrm{~m}$. In $50 \mathrm{~m}$ of water, a $6 \mathrm{~s}$ wave causes $u_{b}$ of only $0.02 \mathrm{~m} \mathrm{~s}^{-1}$ at the bottom. A $12 \mathrm{~s}$ wave in $100 \mathrm{~m}$ of water, on the other hand, causes a $u_{b}$ of $0.16 \mathrm{~m} \mathrm{~s}^{-1}$, and in $50 \mathrm{~m}$ of water the $u_{b}$ is $0.66 \mathrm{~m} \mathrm{~s}^{-1}$. Although our analysis is not yet complete, we can safely guess that the $u_{b}$ caused by a $6 \mathrm{~s}$ wave in either $100 \mathrm{~m}$ or $50 \mathrm{~m}$ of water will be insufficient to cause resuspension. Therefore, we will continue with the $12 \mathrm{~s}$ wave at $100 \mathrm{~m}$.

This wave orbital velocity is combined with $u_{a}$ the current velocity and used in the following equation: $\alpha=1+\left(\frac{\left|u_{a}\right|}{\left|u_{b}\right|}\right)^{2}+2\left(\frac{\left|u_{a}\right|}{\left|u_{b}\right|}\right) \cos \varphi_{c}$, where $\varphi_{c}$ is the angle between the current and wave velocity (Grant and Madsen 1979). Considering current velocities predicted by the Nobeltec software package and desiring to select a conservative value for $u_{a}$ applicable throughout the Gulf of Maine, we chose $0.5 \mathrm{knots}$, or $0.25 \mathrm{~m} \mathrm{~s}^{-1}$. For $\varphi_{c}$ we will use $45^{\circ}$. Substituting these values into the above equation, we find $\alpha=1+\left(\frac{0.16 \frac{m}{s} \mid}{\left|0.25 \frac{m}{s}\right|}\right)^{2}+2\left(\frac{0.16 \frac{m}{s} \mid}{\left|0.25 \frac{m}{s}\right|}\right) \times 0.707=5.8$. The friction factor $f_{c w}$ value 0.02 is derived from $\frac{\left|u_{a}\right|}{\left|u_{b}\right|}$ and $k / A_{b}$ (where $k$ is roughly twice the ripple height, or $2 \mathrm{~cm}$ on smooth mud, the likely topography of a depositional environment with high cyst concentration) and $A_{b}$, the excursion amplitude, which equals $u_{b} / \omega$ were $\omega$ is the wave frequency in radians using Grant and Madsen's (1979) Figure 4. Once $\alpha$ and $f_{c w}$ are known, we can solve for $u_{*}$ from the relationship: $\left|u_{*}\right|=\left(\frac{1}{2} f_{c w} \alpha\right)^{\frac{1}{2}}=\left(\frac{1}{2} 0.02 \times 5.8\right)^{\frac{1}{2}}=0.038 \frac{\mathrm{m}}{\mathrm{s}}$ or 
$3.8 \mathrm{cms}^{-1} . u_{*}$ is used in turn to solve for shear stress, $\tau$, from the relationship $u_{*}=\left(\frac{\tau}{\rho}\right)^{\frac{1}{2}}$, yielding a value of $14.9 \frac{\mathrm{g}}{\mathrm{cms}^{2}}$, well in excess of our critical benthic shear of $0.18 \frac{\mathrm{g}}{\mathrm{cms}^{2}}$. In short, all cysts, or cyst-sized particles, on the bottom in water $100 \mathrm{~m}$ deep or less will be resuspended by $5 \mathrm{~m}$ swells with periods of $12 \mathrm{~s}$.

This analysis of the potential for resuspension in the Gulf of Maine helps to explain the apparent relationship between depth and benthic cyst distribution (see Figure 11) and suggests that the distribution of benthic cysts in the Gulf of Maine is strongly affected by resuspension. One can be almost certain that cysts are regularly delivered to the water column. To what height in the water column they are raised depends in part on the strength of stratification. If stratification is strong, the pycnocline will be the upper limit to which cysts may be resuspended. If the water column is well-mixed top to bottom, cysts may be resuspended into the surface waters. Thus, there is likely a seasonal component to the delivery of cysts to the surface waters; not only is storm swell more common in winter months, the lack of stratification ensures that, if turbulent energy is sufficient, cysts may be delivered to the surface. Likewise, areas where cysts reach the surface may be limited by water depth and tidal velocity. The water over Jordan Basin, as Figure 26 illustrates, is always well-stratified, but the water near shore and in the Bay of Fundy is always well-mixed.

These lines of reasoning are equally applicable to hypnozygote cysts and to planomeiocytes or vegetative cells trying to swim up to the surface from the benthos. This physical mechanism by which motile cells may be delivered to the surface in no way 
negates the fact that cysts in the water column, ensured of oxygen and perhaps exposed to light, will be more likely to germinate than those on the bottom.

\section{Estimate of Error}

The goal of this study was to determine whether or not $A$. fundyense hypnozygote cysts were suspended in the water column in the Gulf of Maine. The methods used were adequate to meet this goal of determining absence or presence. Having found suspended cysts, the next important step is to evaluate their distribution and abundance. Our methods are not as well suited to attaining these goals, although we can begin this evaluation using the results of this study if we are sufficiently careful. In order to evaluate the importance of the data, potential errors from all sources must be identified and addressed.

Beginning with sample collection, the first source of error comes from the inexact method of measuring liters sieved. This was done by eye by estimating the distance between the water level and the nearest liter mark on a 20 liter carboy. The average amount of water recovered from the Niskin bottles for sieving on the February cruise was 17.5 liters in surface samples, and 26 liters in top of the bottom nepheloid and near bottom samples. Therefore, February sample volumes may have an error of 0.25 liters per 17.5 liters, or $1.4 \%$ in surface samples, and 0.25 liters per 26 liters in top of the bottom nepheloid and near bottom samples, or $1 \%$. In the April-May cruise the average sample volume sieved was 27.9 liters, with a possible error of $0.9 \%$. The June cruise volumes also had a $0.9 \%$ error associated with them. Propagated through the cysts per cubic meter calculation, this error remains near $1 \%$; if two cysts were counted in a 
sample, and the volume sieved was $23 \pm 0.25$ liters, the cysts per cubic meter calculation gives $87 \pm 1$ cysts $\mathrm{m}^{-3}$, or $87 \pm 1 \%$. This amount of error is not considered serious.

Perhaps the largest source of uncertainty in the data comes from the lack of duplicate samples. Plankton are known to be patchily distributed in space (McAlice 1970) as a result of microenvironments of physical forces, gradients in physical forces, grazing, and biological processes (division rates, behaviors, etc.). The hypnozygote cysts are dormant and immotile so the biological factors may be eliminated, but the other forces are more than adequate to cause patchiness in suspended sediments or hypnozygote cysts. We used the largest Niskin bottles available to us to maximize our sample size, which reduced sampling error from what it would have been with smaller sample sizes, but no duplicates were taken so we cannot conclude that our samples were representative or not of the environments in which they were taken. We cannot know if our sample size was adequate because without duplicates we do not know how much variation existed between sites.

There is a possibility that some cysts were lost in the sample preparation, either during the initial sieving step or during an aspiration following one of the many centrifugation steps. Aspirations were performed very conservatively by hand pipette rather than vacuum pump because this method offered more control. Aspirated material, however, was not examined so no quantitative assessment of losses exists. Given the density of cysts $\left(1.2 \mathrm{~g} \mathrm{~cm}^{-3}\right)$, they were most likely deep in the centrifuge pellet rather than still suspended following centrifugations; loss of cysts from aspiration is likely negligible. Some loss of cysts may have occurred during the sieving process on the ship. No microscopic examinations of sieve screens were performed. 
Counting errors are also unquantifiable, as replicate counts of samples were not done. Some samples required multiple counts to complete because they were larger than $1 \mathrm{ml}$, but no attempt was made to make these counts even. That is, the sample was vortexed and $1 \mathrm{ml}$ was removed by pipette and dispensed onto the Sedgwick-Rafter cell, but that milliliter was taken from the bottom of the centrifuge tube where the heavier particles had already begun to settle. Each sample was counted in its entirety, which eliminated any error that might have been associated with subsampling.

Every attempt was made to get all the particulate material from the centrifuge tube into the Sedgwick-Rafter counting cell. If there was not a lot of particulate material in the sample this was easily accomplished. If the sample contained a lot of particulate material the centrifuge tube was rinsed with $1 \mathrm{ml}$ of distilled deionized water and that was counted. A. fundyense hypnozygote cysts were identified conservatively. If cysts were not in the correct size range $(40-60 \mu \mathrm{m}$ by $20-30 \mu \mathrm{m})$, if they lacked the double cyst wall, if they did not have the right appearance in transmitted or epifluorescent light they were not included in the cyst totals. Therefore, if error exists in the count data, the data underestimates, rather than overestimates the actual concentrations of cysts.

Cysts concentrations are reported per cubic meter of water. If a smaller unit were used (a liter, for example), we would be faced with reporting partial cysts. Scaling up to one cubic meter from roughly 30 liters does magnify error, but it does not introduce any. We report medians as an estimate of central tendency rather than means because of the large number of zeroes in the data set. A mean would be inappropriately skewed by these zero values.

Although the potential errors in this suspended cyst data set are many, all of the error would result in under-reporting of cyst densities rather than over-reporting. 
Whether or not this data set statistically represents the abundance and distribution of suspended cysts in the Gulf of Maine is impossible to determine. 


\section{CONCLUSIONS}

When cysts were identified as a stage in the A. fundyense life cycle, they explained things that had previously been mysteries: why vegetative cells had not been observed in winter months but blooms recurred every spring or summer, why recurring blooms were observed in years following first-time ever events (the 1972 event having apparently "seeded" the Cape Cod region, for example). Further study in salt ponds revealed cyst germination triggers: temperature and light seemed most important until laboratory studies added oxygen and an endogenous clock to the list of factors. Notably, only a small fraction of benthic cysts germinated in a given year, even among those that were exposed to favorable conditions. Bloom densities apparently develop by asexual reproduction in the vegetative cell stage. The mysteries seemed all but solved, and they probably are for salt ponds and other semi-enclosed, shallow bodies of water with recurring $A$. fundyense problems.

When we began investigating the offshore A. fundyense populations in the Gulf of Maine, researchers began to approach this wider, deeper environment using what they knew; cysts were on the bottom in great numbers, recurring vegetative cell populations were observed in the surface, therefore the endogenous clock must cause benthic cysts to germinate. Although the endogenous clock can cause germination in the absence of light, germination rates are slow (1-2\% per day) (Anderson and Keafer 1987; Matrai, personal communication). Oxygen, light, and warmer temperatures have been shown significantly enhance germination rates in many research studies (Anderson, Taylor, Armbrust 1987; Anderson and Keafer 1987; Anderson and Wall 1978; Anderson and Morel 1979). 
This brings us back to where we began: $A$. fundyense vegetative cells are observed annually in the Gulf of Maine, great densities of $A$. fundyense cysts are observed in bottom sediment samples. The next questions to be addressed are: where exactly are the benthic cysts located in the physical environment of the Gulf of Maine, and why are the cyst beds where they are and not elsewhere? The second question is perhaps easier to address than the first. Cysts form in the water column and then become passive particles, just like any other, subject to the physical forces in the water column. They will fall to the bottom in areas where deposition is favored. Sporadic high shear stress events will likely resuspend them, and then they will resettle to the bottom. Few particles that touch the bottom will rest forever where they land. The location of cyst beds, especially deep cyst beds, is more likely a reflection of the physical properties of the water and sediment dynamics than of the location of any ecological process (cyst formation or bloom initiation).

It should be said, however, that these cyst beds might not represent a pure sink for hypnozygote cysts. Areas of cyst accumulation certainly reflect the average environment of the area (favorable to deposition), but transient events may resuspend these cysts and vertical mixing and convection might bring them to the surface or advection may transport them far from their benthic origin. Given the gyre-like circulation in the Gulf of Maine, cysts are probably recirculated more than once (Bigelow 1927; Brooks 1985).

A. fundyense hypnozygotes are found nearly everywhere in the sediments and waters of the Gulf of Maine. Which of these sources is most important to springtime vegetative cell population initiation is a far more difficult question to answer. It is tempting to write off the deep, offshore benthic cysts beds with great accumulations of cysts as purely sinks for $A$. fundyense. They may, however, be great sources of cysts for 
resuspension by sporadic high shear stress events. Even low numbers of cysts suspended in the water column can likewise not be dismissed; despite their low numbers, cysts suspended in surface waters are ideally positioned for successful germination. Relative to the low fraction of benthic cysts that might germinate, the water column cyst densities may in fact be significant.

Whether the suspended cysts sampled in this study represent cysts that were resuspended or had not yet settled is not known. Resuspension is likely, given the strength of winter storm-generated mixing and the lack of stratification in the wintertime gulf. Analysis of late winter storm activity and strength of the subsequent summer blooms, however, are not likely to be coupled. Springtime establishment of the vegetative cell population and the formation of bloom densities of vegetative cells apparently rely on different factors (Anderson et al. 1983).

What do the densities of cysts found by this work represent in terms of bloom potential? If in February only one cyst per cubic meter germinated, using sub-optimal growth rates by April the density of vegetative cells would be in the tens to hundreds of cells per liter. In February 2000 there were hundreds of cysts per cubic meter in the Bay of Fundy, as well as vegetative cells, whose presence indicated that seasonal germination had begun. In April 2000 there were tens of cells per liter in the Bay of Fundy. It is therefore possible for suspended cysts to initiate the vegetative cell population. This work has reconfirmed previous conclusions that planktonic populations of dormant cysts must be considered when assessing potential microalgal inoculums (Nehring 1996).

In 1978 Dale et al. argued for the importance of the dormant dinoflagellate stages present in sediments to harmful algal bloom research. This work supplies evidence for a similarly new and potentially important idea: the inclusion of suspended cysts in harmful 
algal bloom research and theory. A. fundyense is a genus of dinoflagellates present in the Gulf of Maine that produces a neurotoxin that can accumulate in shellfish feeding on $A$. fundyense, rendering those shellfish poisonous to humans. A. fundyense produces a sexually formed dormant stage called a hypnozygote cyst. Previous work has established that $A$. fundyense blooms develop not from mass germination of these cysts, but from the mitotic division of vegetative cells. Although cysts densities in the water column are orders of magnitude less than cysts on the bottom, the cysts in the water column are exposed to oxygen, light, and temperatures favorable to excystment and are, I argue, numerous enough to contribute materially to the vegetative cell densities observed in spring and summer.

Dale et al. (1978) also raised the question of the importance or implications of the deep, offshore cyst beds: were they merely sinks where cysts accumulated and decomposed, or could they be resuspended by "upwelling or storm activity" and "carried back up to the photic zone to reestablish offshore plankton blooms?" The authors favored the latter theory, their only reason being the absence of obviously old cysts in these offshore beds. While this line of reasoning is fairly tenuous, their conclusion makes intuitive sense. Cysts are silt-sized particles, subject to physical processes of deposition, erosion, resuspension, etc. The offshore areas where cysts accumulate with sediments are likely areas where sedimentation is favored; these cyst and sediment deposits can represent a potential source for blooms if they are resuspended into the photic zone.

A. fundyense vegetative cells are normally present in the Gulf of Maine in low densities. Blooms develop only when a number of conditions converge (nutrient levels and light high, low losses by advection and grazing, low densities of competitive species, etc.). Favorable conditions can lead to bloom densities of vegetative cells, even if cells 
were initially present in only low densities before favorable conditions developed. If just one cyst per 1000 liters germinates in the Bay of Fundy in February by April cell densities could reach tens to hundreds of cells per liter. Hypnozygote cysts concentrations observed in the water column in this study are high enough to contribute significantly to the spring vegetative cell populations. 


\section{FUTURE WORK}

More rigorous sampling at more depths at regular intervals from February to June would refine our understanding of the spatial and temporal concentrations of suspended hypnozygote cysts, however, the data from this study are compelling evidence that planktonic cysts are important. Further work might be better spent on more novel approaches, such as molecular techniques, laboratory studies, in situ observations of resuspension of sediment from areas known to have high concentrations of cyst, and in situ observations of sexual reproduction. Molecular techniques might be used to determine how closely vegetative cells are related to one another as a means of determining how many cysts inoculate the spring population. A laboratory study to determine how long a planomeiocyte cell, or a vegetative cell, can swim in the dark would help constrain the time window in which a planomeiocyte cell, or new vegetative cell, must reach the photic zone. More work is needed to resolve germination dynamics

as well. Better understanding of where and when benthic shear stress can resuspend cysts and vertical mixing can deliver resuspended cysts to the upper water column would shed light on where the spring vegetative population originates. Work characterizing the factors leading to sexual reproduction, such as population concentration, nutrient concentrations, light, and turbulence would be invaluable for determining the areas of origin for cysts. Likely areas for sexual reproduction are in the Bay of Fundy and in the frontal region south of Penobscot Bay.

Germination of even low densities of cysts in February in the Bay and suboptimal growth rates are consistent with the vegetative cell densities observed later in the spring. While making these conclusions is tempting, more work needs to be done before 
they can be confidently made. Specifically, an evaluation of cyst concentrations through time and in relation to resuspension events (spring tides, significant ocean swell, storms, etc.), and more importantly an evaluation of the germination of suspended cysts and the survival and fate of these early planomeiocytes must be undertaken. It is likely that low concentrations of vegetative cells are present in the Bay of Fundy before June;

characterizing the population dynamics in the unsettled environment of spring in the Gulf of Maine might lead to better understanding of vegetative cell population dynamics in general.

The goal of ECOHAB-GOM is to understand A. fundyense dynamics sufficiently to be able to make accurate predictions of the onset of toxicity in shellfish in the Gulf of Maine. Hypnozygote cysts are essential to the establishment of new vegetative populations of $A$. fundyense each spring, without which blooms would not occur. Current modeling efforts are focused on benthic cyst populations mapped by Anderson et al. (1997 unpublished, Figure 11). This work has established the potential of suspended hypnozygote cysts to initiate the $A$. fundyense vegetative cell population. Understanding hypnozygote cyst dynamics may never lead directly to accurate predictions of PSP toxicity, however, cyst dynamics may help researchers to better understand $A$. fundyense springtime population initiation. 


\section{BIBLIOGRAPHY}

Anderson, D. M. and D. Wall. 1978. Potential importance of benthic cysts of Gonyaulax tamarensis and G. excavata in initiating toxic dinoflagellate blooms. Journal of Phycology. 14:(2): 224-234.

Anderson, D. M. and F. M. M. Morel. 1979a. The seeding of two red tide blooms by the germination of benthic Gonyaulax tamarensis hypnocysts. Estuarine and Coastal Marine Science. 8:279-293.

Anderson, D. M. and F. M. M. Morel. 1979b. Toxic dinoflagellate blooms in the Cape Cod region of Massachusetts. Toxic Dinoflagellate Blooms. D. L. Taylor and H. H. Seliger. New York, Elsevier/North-Holland: 145-150.

Anderson, D. M. 1980. Effects of temperature conditioning on development and germination of Gonyaulax tamarensis (Dinophyceae) hypnozygotes. Journal of Phycology. 16:166-172.

Anderson, D. M., D. G. Aubrey, M. A. Tyler and D. W. Coats. 1982a. Vertical and horizontal distributions of dinoflagellate cysts in sediments. Limnology and Oceanography. 27:(4): 757-765.

Anderson, D. M., D. M. Kulis, J. A. Orphanos and A. R. Cuervels. 1982b. Distribution of the toxic dinoflagellate Gonyaulax tamarensis in the southern New England region. Estuarine, Coastal and Shelf Science. 14:447-458.

Anderson, D. M., S. W. Chisholm and C. J. Watras. 1983. Importance of life cycle events in the population dynamics of Gonyaulax tamarensis. Marine Biology. 76:179-189. 
Anderson, D. M. and B. A. Keafer. 1985. Dinoflagellate cyst dynamics in coastal and estuarine waters. Toxic Dinoflagellates. D. M. Anderson, A. W. White and D. G. Baden. New York, Elsevier Science Publishing: 219-224.

Anderson, D. M. and N. L. Lindquist. 1985. Time-course measurements of phosphorus depletion and cyst formation in the dinoflagellate Gonyaulax tamarensis Lebour. Journal of Experimental Marine Biology and Ecology. 86:1-13.

Anderson, D. M., J. J. Lively, E. M. Reardon and C. A. Price. 1985. Sinking characteristics of dinoflagellate cysts. Limnology and Oceanography. 30:(5): 1000-1009.

Anderson, D. M. and B. A. Keafer. 1987. An endogenous annual clock in the toxic marine dinoflagellate Gonyaulax tamarensis. Nature. 325:616-617.

Anderson, D. M., C. D. Taylor and E. V. Armbrust. 1987. The effects of darkness and anaerobiosis on dinoflagellate cyst germination. Limnology and Oceanography. 32:(2): 340-351.

Anderson, D. M., B. A. Keafer, P. A. Matrai, and M. Keller. 2000. Alexandrium cyst dynamics in the Gulf of Maine. Abstract in Symposium on Harmful Marine Algae in the U. S., by Marine Biological Laboratory, Woods Hole, MA.

Balech, E. and K. Tangen. 1985. Morphology and taxonomy of toxic species in the tamarensis group (Dinophyceaee): Alexandrium excavatum (Braarud) comb. nov. and Alexandrium ostenfeldii (Paulsen) comb. nov. Sarsia. 70:333-343.

Bond, R. M. 1975. Management of PSP in Canada. Proceedings of the First International Conference on Toxic Dinoflagellate Blooms. V. R. LoCicero. Boston, Massachusetts Technology Foundation, Inc. 
Brown, J., L. Fernand, K. J. Horsburgh, A. E. Hill and J. W. Read. 2001. Paralytic shellfish poisoning on the east coast of the UK in relation to seasonal densitydriven circulation. Journal of Plankton Research. 23:(1): 105-116.

Dale, B. 1977. Cysts of the toxic red-tide dinoflagellate Gonyaulax excavata (Braarud) Balech from Oslofjorden, Norway. Sarsia. 63:(1): 29-34.

Dale, B., C. M. Yentsch and J. W. Hurst. 1978. Toxicity in resting cysts of the red-tide dinoflagellate Gonyaulax excavata from deeper water coastal sediments. Science. 201: 1223-1225.

Deitz, A. and D. W. Townsend. 2000. Occurrence of Alexandrium ostenfeldii in the Gulf of Maine. Abstract in Symposium on Harmful Marine Algae in the U. S., by Marine Biological Laboratory, Woods Hole, MA.

Doucette, G. J., A. D. Cembella and G. L. Boyer. 1989. Cyst formation in the red tide dinoflagellate Alexandrium tamarense (Dinophyceae): effects of iron stress. Journal of Phycology. 25: 721-731.

Evitt, W. R. 1985. Sporopollenin dinoflagellate cysts: their morphology and interpretation. Austin, Texas, Hart Graphics.

Grant, W. D. and O. S. Madsen. 1979. Combined wave and current interaction with a rough bottom. Journal of Geophysical Research. 84:(C4): 1797-1808.

Hallegraeff, G. M. 1993. A review of harmful algal blooms and their apparent global increase. Phycologia. 32:(2): 79-99.

Hartwell, A. D. 1975. Hydrographic factors affecting the distribution and movement of the toxic dinoflagellates in the western Gulf of Maine. Toxic Dinoflagellate Blooms. D. L. Taylor and H. H. Seliger. New York, Elsevier/North-Holland. 1: 235-238. 
Heiskanen, A. -S. 1993. Mass encystment and sinking of dinoflagellates during a spring bloom. Marine Biology. 116:161-167.

Hurst, J. W. 1975. History of paralytic shellfish poisoning on the Maine Coast 19581974. Proceedings of the First International Conference on Toxic Dinoflagellate Blooms. V. R. LoCicero. Boston, Massachusetts Technology Foundation, Inc.: 525-528.

Ichimi, K., M. Yamasaki, Y. Okumura and T. Suzuki. 2001. The growth and cyst formation of a toxic dinoflagellate, Alexandrium tamarense, at low water temperatures in northeastern Japan. Journal of Experimental Marine Biology and Ecology. 261:17-29.

Ippen, A. T. 1966. Estuary and Coastline Hydrodynamics. McGraw Hill Book Company, New York.

Kamykowski, D., R. E. Reed and G. J. Kirkpatrick. 1992. Comparison of sinking velocity, swimming velocity, rotation and path characteristics among six marine dinoflagellate species. Marine Biology. 113:319-328.

Keafer, B. A., K. O. Buesseler and D. M. Anderson. 1992. Burial of living dinoflagellate cysts in estuarine and nearshore sediments. Marine Micropaleontology. 20:147-161.

Lewis, C. M., C. M. Yentsch and B. Dale. 1979. Distribution of Gonyaulax excavata resting cysts in the sediments of Gulf of Maine. Toxic Dinoflagellate Blooms. D. L. Taylor and H. H. Seliger. New York, Elsevier/North-Holland. 1: 235-238.

Loder, J. W. and D. A. Greenberg. 1986. Predicted positions of tidal fronts in the Gulf of Maine region. Continental Shelf Research. 6:(3): 397-414. 
MacAlice, B. J. 1970. Small-scale distribution of phytoplankton. Marine Biology. 7:100-111.

MacIntyre, J. G., J. J. Cullen and A. D. Cembella. 1997. Vertical migration, nutrition and toxicity in the dinoflagellate Alexandrium tamarense. Marine Ecology Progress Series. 148:201-216.

MacKenzie, L., D. White, Y. Oshima and J. Kapa. 1996. The resting cyst and toxicity of Alexandrium ostenfeldii (Dinophyceae) in New Zealand. Phycologia. 35:(2): 148-155.

Martin, J. L. and A. W. White. 1982. Distribution and abundance of the toxic dinoflagellate Gonyaulax excavata in the Bay of Fundy. Canadian Journal of Fisheries and Aquatic Sciences. 45:1968-1975.

Mulligan, H. F. 1975. Oceanographic factors associated with New England red tide blooms. Proceedings of the First International Conference on Toxic Dinoflagellate Blooms. V. R. LoCicero. Boston, Massachusetts Technology Foundation, Inc.: 23-40.

Needler, A. B. 1949. Paralytic Shellfish Poisoning and Goniaulax tamarensis. Journal of Fisheries Research Board Canada. 7:(8): 490-504.

Nehring, S. 1996. Recruitment of planktonic dinoflagellates: Importance of benthic resting stages and resuspension events. Int. Revue ges. Hydrobiology. 81:(4): 513-527.

Pettigrew, N. R., D. W. Townsend, H. Xue, J. P. Wallinga, P. J. Brickley and R. D. Hetland. 1998. Observations of the Eastern Maine Coastal Current and its offshore extensions in 1994. Journal of Geophysical Research. 103:(C13): $30,623-30,639$. 
Prakash, A. 1963. Source of paralytic shellfish toxin in the Bay of Fundy. Journal of Fisheries Research Board Canada. 20:(4): 983-996.

Reid, P. C. 1978. Dinoflagellate cysts in the plankton. New Phytol. 80:219-229.

Sarjeant, W. A. S. 1974. Fossil and Living Dinoflagellates. London and New York, Academic Press.

Sasner, J. J., Jr. 1975. The 1972 red tide in New Hampshire. Proceedings of the First International Conference on Toxic Dinoflagellate Blooms. V. R. LoCicero. Boston, Massachusetts Technology Foundation, Inc.

Scholin, C. A., G. M. Hallegraeff and D. M. Anderson. 1995. Molecular evolution of the Alexandrium tamarense 'species complex' (Dinophyceae): dispersal in the North American and West Pacific regions. Phycologia. 34:(6): 472-485.

Simpson, J. H. and Hunter

Souza, A. J., T. D. Dickey and G. C. Chang. 2001. Modeling water column structure and suspended particulate matter on the Middle Atlantic continental shelf during the passages of Hurricanes Edouard and Hortense. Journal of Marine Research. 59:1021-1045.

Taylor, F. J. R. 1987. The Biology of Dinoflagellates. Boston, Blackwell Scientific Publications.

Thompson, B., P. A. Matrai, and M. Keller. 2000. Annual excystment of Alexandrium hypnozygotes from eastern Gulf of Maine populations. Abstract in Symposium on Harmful Marine Algae in the U. S., by Marine Biological Laboratory, Woods Hole, MA. 
Townsend, D. W., J. P. Christensen, D. K. Stevenson, J. J. Graham and S. B. Chenoweth. 1987. The importance of a plume of tidally-mixed water to the biological oceanography of the Gulf of Maine. Journal of Marine Research. 45:699-728.

Townsend, D. W., N. R. Pettigrew and A. C. Thomas. 2001. Offshore blooms of the red tide dinoflagellate Alexandrium sp., in the Gulf of Maine. Continental Shelf Research. 21:347-369.

Townsend, D. W. and A. C. Thomas. 2001. Winter-spring transition of phytoplankton chlorophyll and inorganic nutrients on Georges Bank. Deep-Sea Research Part II. 48:199-214.

Turpin, D. H., P. E. R. Dobell and F. J. R. Taylor. 1978. Sexuality and cyst formation in Pacific strains of the toxic dinoflagellate Gonyaulax tamarensis. Joumal of Phycology. 14:(2): 235-238.

White, A. W. and C. M. Lewis. 1982. Resting cysts of the toxic, red tide dinoflagellate Gonyaulax excavata in Bay of Fundy sediments. Canadian Journal of Fisheries and Aquatic Sciences. 39:1185-1194.

Wyatt, T. and I. R. Jenkinson. 1997. Notes on Alexandrium population dynamics. Journal of Plankton Research. 19:551-575.

Yamaguchi, M., S. Itakura, I. Imai and Y. Ishida. 1995. A rapid and precise technique for enumeration of resting cysts of Alexandrium spp. (Dinophyceae) in natural sediments. Phycologia. 34:(3): 207-214.

Yamamoto, T., T. Seike, T. Hashimoto and K. Tarutani. 2002. Modelling the population dynamics of the toxic dinoflagellate Alexandrium tamarense in Hiroshima Bay, Japan. Journal of Plankton Research. 24:(1): 33-47. 
Yentsch, C. M., C. M. Lewis and C. S. Yentsch. 1980. Biological resting in the dinoflagellate Gonyaulax excavata. BioScience. 30:(4): 251-254.

Yentsch, C. M. and F. C. Mague. 1979. Motile cells and cysts: Two probable mechanisms of intoxication of shellfish in New England Waters. Toxic Dinoflagellate Blooms. D. L. Taylor and H. H. Seliger. New York, Elsevier/North-Holland. 1: 127-130. 


\section{BIOGRAPHY OF THE AUTHOR}

Sarah Landon Kirn was born in Pittsburgh, Pennsylvania on April 9 1972. After a brief sojourn in the state that also gave birth to our nation, she began her quest to live in every state in New England. Connecticut and New Hampshire were inhabited by the author thanks to moves arranged by her parents. Massachusetts was accomplished during her high school career, the last three years of which were spent at Phillips Academy, Andover, Massachusetts. Significantly, the author's boating experience started in Massachusetts as she rowed on Andover's varsity crew team, winning the interscholastic championships in both her junior and senior years. The author graduated from that fine institution in 1990 with Honors in Art.

Rhode Island came next on the list, as, during a year away from academics following high school, the author pursued her romance with the sea as an apprentice on the Sloop Providence, a reproduction the revolutionary war ship that was John Paul Jones' first command - the "fast ship" that he would sail with so much success "into harm's way." After spending the summer of 1991 on the Schooner Mary Day on the coast of Maine, her freshman year of college at Cornell University, and a semester with Sea Education Association, the author resumed her residence in Rhode Island when she transferred to Brown University. The year spent at Cornell University, although an unhappy experience, was the first exposure Sarah had to oceanography.

Brown University was a much better place for Sarah. Concentrating in geologybiology, she pursued her interests in coastal environments. Two research trips to Mt. Rainier in Washington State capped her undergraduate science experience and gave her a subject for her senior thesis ("The Petrology of a Mount Rainier Pyroclastic Eruption"). She finished her undergraduate career in December of 1994, but remained for a final 
spring semester as a post bachelaureate student to complete the requirements for medical school. She graduated Magna Cum Laude from Brown University as a member of the class of 1994.5.

Sarah returned to the sea after graduation, working in various capacities on sail boats and earning her USCG 100 ton Inland Master, 150 ton Near Coastal Mate of Auxiliary Sail Vessels license in June of 1996. As a summertime instructor in the sea program of the Hurricane Island Outward Bound School, she gained intimate knowledge of the coast of Maine. During her winters she pursued other adventures, including sailing transatlantic, working as a hiking guide in Europe, and working at the Montshire Museum in Vermont (so completing her quest to live in all of the New England states). When her curiosity about the ocean she was sailing through overcame her enjoyment of living in a pulling boat all summer and finding odd jobs all winter, she decided to pursue a graduate degree in oceanography.

Sarah is a candidate for the Master of Science degree in Oceanography from The University of Maine in August 2002. 